\title{
Bibliografia historii wychowania, szkolnictwa i myśli pedagogicznej w Polsce za rok 2005 (z uzupelnieniami za lata poprzednie)
}

Bibliografia rejestruje druki zwarte, artykuły z czasopism i prac zbiorowych. Obejmuje pozycje wydane w 2005 r. oraz te, które nie znalazły się w poprzednich częściach bibliografii publikowanych na łamach Biuletynu Historii Wychowania od 2002 r. Bibliografia ma układ rzeczowy według podanego niżej schematu. W poszczególnych działach i poddziałach (z wyjątkiem poddziału 5. Szkoły wyższe w Dziale III, gdzie zastosowano układ według nazw szkół oraz poddziału 2. Poszczególne biografie w Dziale IV, w którym pozycje ułożone zostały według nazwisk osób) zastosowano układ alfabetyczny według haseł autorskich lub tytułowych. Opisy w razie potrzeby uzupełniono adnotacjami.

I. Opracowania ogólne. Bibliografie

II. Rozwój oświaty, wychowania i myśli pedagogicznej

1. Opracowania ogólne

2. Okres do 1795 roku

3. Okres $1795-1918$

4. Okres 1918-1939

5. Okres 1939-1945

6. Okres $1945-1989$

7. Okres 1989-2005

8. Oświata polonijna

III. Dzieje szkół różnych stopni

1. Szkoły podstawowe i zakłady wychowawcze

2. Szkoły średnie ogólnokształcące

3. Szkoły zawodowe

4. Zakłady kształcenia nauczycieli (z wyjątkiem szkół wyższych)

5. Szkoły wyższe

IV. Teoretycy wychowania i działacze oświatowi

1. Zbiory życiorysów

2. Poszczególne biografie

V. Dzieje oświaty pozaszkolnej

1. Oświata dorosłych

2. Biblioteki

VI. Dzieje ruchu nauczycielskiego

1. Opracowania ogólne i monografie

2. Pamiętniki nauczycieli

VII. Organizacje młodzieżowe 


\section{WYKAZ SKRÓTÓW CZASOPISM}

Acta UNC - Acta Universitatis Nicolae Copernici

Acta UL - Acta Universitatis Lodziensis

Acta Univ. Wr. - Acta Universitatis Wratislaviensis

Almanach Hist. - Almanach Historyczny

Almanach Sądec. - Almanach Sądecki

Annales APC - Annales Academiae Padegaogiae Cracoviensis

Annales UMCS - Annales Universitatis Mariae Curie-Skłodowska

Arch. Hist. i Filoz. Med. - Archiwum Historii i Filozofii Medycyny

Ateneum Kapl. - Ateneum Kapłańskie

Biul. UJ - Biuletyn Biblioteki Jagiellońskiej

Częstoch. Studia Teol. - Częstochowskie Studia Teologiczne

Gdań. Zap. Hist.-Społ. - Gdańskie Zapiski Historyczno-Społeczne

Kom. Mazur.-Warm. - Komunikaty Mazursko-Warmińskie

Krak. Rocz. Archiw. - Krakowski Rocznik Archiwalny

Krak. Studia Małop. - Krakowskie Studia Małopolskie

Kron. Bydg. - Kronika Bydgoska

Kutn. Zesz. Region. - Kutnowskie Zeszyty Regionalne

Kw. Hist. Nauki i Techn. - Kwartalnik Historii Nauki i Techniki

Kw. Hist. Żydów - Kwartalnik Historii Żydów

Kw. Opol. - Kwartalnik Opolski

Maz. Studia Hum. - Mazowieckie Studia Humanistyczne

Miel. Zap. - Mieleckie Zapiski

Nauka Pol.-Potrz. Org. - Nauka Polska - Jej Potrzeby, Organizacja i Rozwój

Pam. Liter. - Pamiętnik Literacki

Piotrk. Zesz. Hist. - Piotrkowskie Zeszyty Historyczne

Pozn. Zesz. Hum. - Poznańskie Zeszyty Humanistyczne

Pr. Hist.-Arch. - Prace Historyczno-Archiwalne

Pr. Komis. Hist. Nauki - Prace Komisji Historii Nauki

Pr. Nauk. Akad. im. J. Długosza - Prace Naukowe Akademii im. Jana Długosza

Pr. Pienińskie - Prace Pienińskie

Pr. Uczes. Stud. Dokt. - Prace Uczestników Studium Doktoranckiego / Uniwersytet Opolski

Prz. Hist. - Przegląd Historyczny

Prz. Hist.-Ośw. - Przegląd Historyczno-Oświatowy

Prz. Nauk. Hist. - Przegląd Nauk Historycznych

Przyj. Ludu - Przyjaciel Ludu

Rocz. Bial.-Podl. Rocznik Bialskopodlaski

Rocz. Bibliot. - Roczniki Biblioteczne

Rocz. Dziej. Społ.-Gosp. - Roczniki Dziejów Społeczno-Gospodarczych

Rocz. Gdań. - Rocznik Gdański

Rocz. Gdyń. - Rocznik Gdyński

Rocz. Grudz. - Rocznik Grudziądzki

Rocz. Hist. - Roczniki Historyczne

Rocz. Hum. - Roczniki Humanistyczne

Rocz. Jel.-Górs. - Rocznik Jeleniogórski

Rocz. Kalis. - Rocznik Kaliski 
Rocz. Kolbusz. - Rocznik Kolbuszowski

Rocz. Konin. - Rocznik Koniński

Rocz. Krak. - Rocznik Krakowski

Rocz. Lud. Tow. Nauk.-Kult. Oddz. w Krakowie - Rocznik Ludowego Towarzystwa Naukowo-Kulturalnego Oddział w Krakowie

Rocz. Lwow. - Rocznik Lwowski

Rocz. Maz. - Rocznik Mazowiecki

Rocz. Mazur. - Rocznik Mazurski

Rocz. Mazurka Dąbrowskiego - Roczik Mazurka Dąbrowskiego

Rocz. Mińsko- Maz. - Rocznik Mińskomazowiecki

Rocz. Muz. Gliw. - Rocznik Muzeum w Gliwicach

Rocz. Nauk. Społ. - Rocznik Nauk Społecznych

Rocz. Pedag. - Rocznik Pedagogiczny

Rocz. Pol. - Niem. Rocznik Polsko-Niemiecki

Rocz. Przem. - Rocznik Przemyski

Rocz. PTN na Obczyźnie - Rocznik Polskiego Towarzystwa Naukowego na Obczyźnie

Rocz. Sądec. - Rocznik Sądecki

Rocz. Tor. - Rocznik Toruński

Rocz. Tow. Liter. Im. A. Mickiewicza - Rocznik Tow. Liter. im. A. Mickiewicza

Rocz. Wołom. - Rocznik Wołomiński

Rozpr. Dziej. Ośw. - Rozprawy z Dziejów Oświaty

Rozpr. Komis. Jęz. - Rozprawy Komisji Językowej

Studenckie Zap. Hist. - Studenckie Zapiski Historyczne

Studenckie Zesz. Nauk. UJ - Studenckie Zeszyty Naukowe Uniwersytetu Jagiellońskiego

Studia Bibliol. AŚ - Studia Bibliologiczne Akademii Świętokrzyskiej

Studia Hist. - Studia Historyczne

Studia Podl. - Studia Podlaskie

Studia Teol. - Studia Teologiczne

Studia Włoc. - Studia Włocławskie

Studia Ziel.-Górs. - Studia Zielonogórskie

Studia Zach. - Studia Zachodnie

Szkice Leg. - Szkice Legnickie

Śl. Kwart. Hist. Sobótka - Śląski Kwartalnik Historyczny Sobótka

Śl. Studia Hist.-Teol. - Śląskie Studia Historyczno-Teologiczne

Wiad. Kośc. Archidiec. Białost. - Wiadomości Kościelne Archidiecezji Białostockiej

Wschodni Rocz. Hum. - Wschodni Rocznik Humanistyczny

Zesz. Hist. - Zeszyty Historyczne

Zesz. Nauk. UJ - Zeszyty Naukowe Uniwersytetu Jagiellońskiego

Zesz. Nauk. Uniw. Rzesz. - Zeszyty Naukowe Uniwersytetu Rzeszowskiego

Zesz. Region. - Zeszyty Regionalne

Ziemia Częstoch. - Ziemia Częstochowska

Ziemia Śl. - Ziemia Śląska 


\section{OPRACOWANIA OGÓLNE. BIBLIOGRAFIE}

1. BIBLIOGRAFIA prac Komisji Historycznej Krakowskiej Chorągwi ZHP 1980-2004. Oprac. Janusz Wojtycza. Kraków 2005 Komisja Hist. Krakowskiej Chorągwi ZHP ss. 60.

2. HISTORIA wychowania w kształceniu nauczycieli. Tradycja i współczesność, teoria i praktyka. Pod red. Teresy Gumuły, Stanisława Majewskiego. Kielce 2005 Wydaw. Akad. Świętokrzyskiej im. J. Kochanowskiego ss. 386, nlb. 2.

Z treści: Gumuła T., Majewski S.: Wstęp. s. 13-14; Cz. I. Historia wychowania jako nauka i dyscyplina akademicka: Dybiec Julian: Historia wychowania w postmodernistycznym świecie s. 19-26; Bartnicka Kalina, Szybiak Irena: Historia wychowania w programie studiów pedagogicznych s. 27-37; Pankowska Krystyna: Myśl klasyków pedagogiki a postępująca liberalizacja współczesnego wychowania s. 39-46; Meissner Andrzej: Polskie podręczniki do historii wychowania po II wojnie światowej s. 47-54; Sztobryn Sławomir: Przyszłość polskiej historii myśli pedagogicznej jako subdyscypliny pedagogicznej s. 63-68; Cz. II. Stanowiska metodologiczne w badaniach historyczno-oświatowych: Szulakiewicz Władysława: „Rozprawy z Dziejów Oświaty” (1958-2002) - pismo historyczno-oświatowe s. 71-78; Gumuła T.: Czterdzieści pięć lat „Przeglądu Historyczno-Oświatowego" s. 79-86; Michalski Grzegorz: Strategia badań stowarzyszeń w historii wychowania s. 87-93; Grzybowski Romuald: Kalendarze nauczycielskie z lat 1927-1957 jako forma upowszechniania wśród nauczycieli realizowanej przez państwo ideologii wychowawczej s. 95-104; Ossowska-Zwierzchowska Aldona: Edukacja i władza - społeczny i polityczny wymiar wychowania w studiach nad starożytnością s. 105-109; Ratajczak Krzysztof: Źródła do dziejów wychowania w średniowieczu - problemy metodologiczne i dydaktyczne s. 111-122; Czapska Małgorzata: Metodologiczne problemy badań nad zbiorowością nauczycieli rządowych, męskich szkół średnich w Królestwie Polskim w latach 1873-1905; Kabzińska Lucja: Dydaktyka ogólna II Rzeczypospolitej - problemy metodologiczne s. 131-143; Szablicka-Żak Jolanta: Sprawozdania stenograficzne i inne dokumenty sejmowe jako źródło badań nad prawodawstwem oświatowym w Parlamencie II Rzeczypospolitej s. 145-150; Głowacka-Sobiech Edyta: Źródła archiwalne w Polsce w badaniach nad dziejami najnowszego wychowania s. 151-155; Majewski S.: Metodologiczne problemy w badaniach nad najnowsza historią oświaty s. 157-163; Cz. III. Znaczenie historii wychowania w przygotowaniu kandydatów na nauczycieli: Michalska Iwonna: Edukacja historyczna pedagogów. Zagadnienia dydaktyczno-metodyczne s. 167-174; Krzanowski Adam, Szmyd Kazimierz: Kształcienie pedagogiczne nauczycieli w świetle dyskursu nad historią wychowania i współczesną myślą pedagogiczną s. 175-184; Wolter Edyta: Znaczenie historii wychowania w kształceniu nauczycieli s. 185-189; Wendreńska Iwona: O nauczaniu historii wychowania dawniej i dziś uwag kilka s. 191-199; Kamińska Janina: Nowe formy kształcenia w zakresie historii wychowania s. 201-204; Buczek Katarzyna: Nowe formy kształcenia w zakresie historii wychowania w opinii studentów Wydziału Pedagogicznego UW - wnioski s. 205-207; Rodek Violetta: Historia wychowania jako przedmiot nauczania z refleksji przyszłego pedagoga s. 209-216; Karcz Eugenia: Historia wychowania w wyższych szkołach niepaństwowych. Praktyka a oczekiwania studentów s. 217-222; Jankowski Robert: Teksty źródłowe w nauczaniu historii wychowania w Uniwersytecie Szczecińskim s. 223-231; Jundzilł Juliusz: Edukacja antyczna w programie nauczania historii wychowania na studiach pedagogicznych s. 233-239; Stawoska-Jundziłł Bożena: Treści związane $\mathrm{z}$ antykiem chrześcijańskim $\mathrm{w}$ dydaktyce historii wychowania na studiach pedagogicznych s. 241-245; Długosz-Biłous Henryka: Aspekty historyczne w kształceniu psychologicznym nauczycieli s. 247-252; Krzystanek Katarzyna, Perz Katarzyna: Psychologia humanistyczna a zmiana modelu nauczycielawychowawcy s. 253-258; Biołus Paweł: Problemy orientacji zawodowej w procesie przygotowania nauczycieli w przeszłości i obecnie s. 259-262; Cz. IV. Edukacja historyczna w ksztaltowaniu postaw patriotyczno-obywatelskich: Kula Ewa, Pękowska Marzenia: Postawy patriotyczne nauczycieli szkół średnich Królestwa Polskiego w świetle pamiętników i wspomnień uczniów s. 273-280; Kula Ewa: Lojalność czy patriotyzm. Historia jako przedmiot zainteresowań naukowych i literackich nauczycieli zatrudnionych w rządowych, męskich szkołach średnich Królestwa Polskiego w latach 1833-1862; Cimała Bogdan: Wpływ postaw patriotyczno-obywatelskich nauczycieli na pracę w szkołach w środowisku ludności mieszanej etnicznie (na przykładzie Śląska Opolskiego) s. 297-308; Sapia-Drewniak Eleonora: Znaczenie języka polskiego w przygotowaniu nauczycieli do pracy na Śląsku Opolskim w okresie międzywojennym s. 309-316; Lapot Mirosław: Lwowski „Przegląd Społeczny” jako trybuna walki o prawa dziecka żydowskiego w okresie międzywojennym s. 317-325; Rędziński Kazimierz: Edukacja interkulturowa w szkolnictwie żydowskich zrzeszeń spolecznych w Małopolsce w latach 
1918-1939 s. 327-334; Szczygieł Mirosława: Działalność Centralnego Komitetu Opieki nad Sierotami Żydowskimi w Zachodniej Małopolsce (1919-1939) s. 335-343; Krześniak-Firlej Danuta, Firlej Waldemar: Kwalifikacje zawodowe duchownych nauczycieli religii rzymskokatolickiej w szkołach II Rzeczypospolitej s. 345-356; Mielczarek Ferdynand: Kształtowanie stosunku nauczycieli do historii ojczystej i tradycji narodowej w latach 1945-1956 s. 357-364; Szkoda Edward: Znaczenie edukacji historycznej w ksztaltowaniu postaw patriotyczno-obywatelskich w okresie Polski Ludowej (na podstawie wybranych regulacji resortu oświaty) s. 365-372.

3. KWIATKOWSKA Henryka: Sprawozdanie z działalności Komitetu Nauk Pedagogicznych PAN za rok 2004. Rocz. Pedag. T. 28: 2005 s. 95-99.

4. ŁOSOWSKA Anna, Łosowski Janusz: Dwugłos w sprawie zadań i funkcji archiwum uniwersyteckiego. Annales UMCS. Sec. F: Historia. Vol. 60: 2005 s. 479-501.

5. MAUERSBER Stanisław: Wychowawca narodu (wybór fragmentów pism i przemówień Józefa Piłsudskiego - w 70. rocznicę jego śmierci). Prz. Hist.-Ośw. R. 48: $2005 \mathrm{nr}$ 3/4 s. 5-35.

6. OPIEKA a edukacja. Studia dedykowane profesorowi Marianowi Byblukowi z okazji 70. rocznicy urodzin. Pod red. Piotra Petrykowskiego. Toruń 2005 Wydaw. UMK ss. 290, il.

$\mathrm{Z}$ treści: Droga życiowa, zawodowa i naukowa Profesora Mariana Byblula s. 13-16; Publikacje Profesora Mariana Bybluka s. 17-26; Pyrzyk Ireneusz: Geneza pedagogiki opiekuńczej a polski pajdocentryzm s. 171-183; Pólturzycki Józef: Modele związków młodzieży w badaniach Aleksandra Kamińskiego s. 201-219; Wodyło Witold: Garść refleksji o edukacji historycznej w stalinizmie s. 229-235; Urlińska Maria Marta: Modele bilingwalne dla szkół polskiej mniejszości narodowej (komunikat $\mathrm{z}$ badań w szkole polskiej w Rydze) s. 267-280; Wesołowska Eugenia A.: Polsko-rosyjskie kontakty pedagogiczne Uniwersytetu Mikołaja Kopernika i Szkoły Wyższej Pawła Włodkowica s. 281-290.

7. ROSNER Anna: Jak badać dzieciństwo i prawa dziecka? Prz. Hist. T. 96: 2005 z. 2 s. 339-348.

8. SZULAKIEWICZ Władysława: $Z$ dziejów związków filozofii i pedagogiki w Polsce w latach 1900-1939. Annales APC. Folia 29: Studia ad Institutionem et Educationem Pertinentia. [T.] 1: 2005 s. $22-35$, abstr.

9. ŚLĘCZKA Ryszard: Ogólnopolski Konkurs Prac Magisterskich z Historii Edukacji im. Profesora Czesława Majorka. Annales APC. Folia 29: Studia ad Institutionem et Educationem Pertinentia. [T.] 1: 2005 s. 174-176.

Od $2001 \mathrm{r}$.

10. WIECZOREK Barbara: Bibliografia pedagogiki 2003. Ksiażki wydane w Polsce (wybór). Rocz. Pedag. T. 28: 2005 s. 249-263.

\section{ROZWÓJ OŚWIATY, WYCHOWANIA I MYŚLI PEDAGOGOCZNEJ}

\section{Opracowania ogólne}

11. ADAMCZYK Daria: Działalność Sekcji Wsparć Niezamożnej Młodzieży Szkolnej przy Towarzystwie Szerzenia Oświaty wśród Żydów w Częstochowie. Ziemia Częstoch. T. 32: 2005 s. $117-131$.

W 1. 1916-1924. 
12. ALEKSANDER Tadeusz: Powszechne wykłady uniwersyteckie w Nowym Sączu (1904-1939). Rocz. Sqdec. T. 33: 2005 s. 52-63.

13. BORKOWSKA Urszula: Edukacja Jagiellonów. Rocz. Hist. R. 71: 2005 s. 99-119, Zsfg. XV-XVI w.

14. BOTANIKA w Toruniu i Bydgoszczy. Z przeszłości i teraźniejszości. Opracowanie zbiorowe. Pod red. Tomasza Załuskiego, Macieja Korczyńskiego i Lucjana Rutkowskiego. BydgoszczTorun 2005 Pol. Tow. Botaniczne. Oddz. ss. 134, tabl. 58, il.

Z treści: Botanika w Toruniu: Rutkowski L.: Zanim powstał Uniwersytet Mikołaja Kopernika s. 13-14; Rutkowski L.: Katedra Botaniki Ogólnej UMK (1945-1966) s. 15-18; Rutkowski L.: Zakład Botaniki Ogólnej UMK (1966-1987) s. 18-21; Rożej Antoni, Rutkowski L.: Zakład Mykologii UMK (1958-1970) s. 23-24; Rutkowski L., Wilkoń-Michalska Jadwiga, Załuski T.: Katedra i Zakład Systematyki i Geografii Roślin UMK (1945-1977) s. 24-28; Rutkowski L., Wilkoń-Michalska J., Załuski T.: Zakład Taksonomii, Ekologii Roślin i Ochrony Przyrody UMK (1977-1988) s. 28-30; Gugnacka-Fiedor Wanda, Rutkowski L., Załuski T.: Zakład Taksonomii i Geografii Roślin UMK s. 30-36; Barcikowski Adam: Zakład Ekologii Roślin i Ochrony Przyrody UMK s. 36-39; Nienartowicz Andrzej: Pracownia Modelowania Procesów Ekologicznych UMK s. 39-44; Michniewicz Marian: Od Katedry Fizjologii Roślin do Zakładu Fizjologii i Biologii Molekularnej Roślin UMK s. 46-53; Michniewicz M.: Zakład Biotechnologii UMK s. 54; Bednarska Elżbieta: Zakład Biologii Komórki UMK s. 55-59; Goc Anna: Zakład Genetyki UMK s. 59-60; Bednarska E.: Pracownia Biologii Rozwoju UMK s. 60-61; Zahuski T., Gugnacka-Fiedor W.: Oddział Toruński Polskiego Towarzystwa Botanicznego s. 62-64; Noryśkiewicz Andrzej, Załuski T.: Oddział Toruński PTB - popularyzacja wiedzy botanicznej s. 65-67; Załuski T.: Trochę historii, czyli książka Zofii Michno-Zatorskiej „Anegdoty, wspominki i refleksje z pierwszego ćwierćwiecza UMK" s. 67-68; Gorska-Poczopko Jadwiga: Jak widziałam początki botaniki na UMK w Toruniu w latach 1946-1950 s. 68-72. Botanika w Bydgoszczy: Korczyński M.: Instytucje botaniczne w Bydgoszczy w okresie rozbiorów s. 73-74; Krasicka-Korczyńska Ewa: Katedra Botaniki i Ekologii Akademii Techniczno-Rolniczej w Bydgoszczy s. 74-77; Drozdowska Lucyna: Katedra Fizjologii Roślin ATR w Bydgoszczy s. 77-80; Nowaczyk Pawel: Katedra Genetyki i Hodowli Roślin ATR w Bydgoszczy s. 80-81; Majtkowski Włodzimierz: Instytut Hodowli i Aklimatyzacji Roślin - Oddział w Bydgoszczy s. 81-82; Majtkowska Gabriela, Majtkowski W.: Ogród Botaniczny IHAR w Bydgoszczy s. 82-86; Wilbrandt Barbara: Ogród Botaniczny Uniwersytetu Kazimierza Wielkiego w Bydgoszczy s. 87-88; Boratyński Adam: Zakład Botaniki UKW w Bydgoszczy s. 89-90; Burczyk Jarosław: Zakład Genetyki UKW w Bydgoszczy s. 91-92; Załuski T.: Katedra i Zakład Biologii i Botaniki Farmaceutycznej Collegium Medicum im. L. Rydygiera UMK s. 92-93; Sylwetki botaników: Rutkowski L., Wilkoń-Michalska J.: Ryszard Bohr (1926-1987) s. 97-98; Majtkowski W.: Maria Chwastek s. 98-99; Bednarska E.: Alicja Górska-Brylass s. 99-101; Majtkowski W.: Barbara Jassem s. 101-102; Sliwińska Elwira: Marek Jassem (1926-2004) s. 102-103; Michniewicz M.: Teresa Kentzer (1930-1992) s. 103-105; Załuski T.: Klemens Kępczyński (1916-1997) s. 105-107; Dziamski Andrzej: Franciszek Klimas (1928-1999) s. 107-108; Korczyński M.: Alfons Kużdowicz (1912-1992) s. 108-109; Kahużna Krystyna: Andrzej Michalski (1904-1973) s. 109-111; Michniewicz M.: Leszek Michalski (1920-1995) s. 111-112; Rożej Barbara: Marian Michniewicz s. 113-114; Krasicka-Korczyńska E., Stosik Tomasz: Józef Misiewicz s. 115; Majtkowski W.: Leontyna Olszewska (1917-2000) s. 115-116; Majtkowski W.: Bolesław Osiński s. 116-118; Majtkowski W.: Maria Szota s. 118-119; Krasicka-Korczyńska E., Stosik T.: Eugeniusz Ryszard Śpiewakowski s. 119-120; Wilkoń-Michalska J.: Jan Walas (1903-1991) s. 121-123; Rutkowski L.: Jadwiga Wilkoń-Michalska (1921-2005) s. 124-126; Rutkowski L., Michno-Zatorska Zofia: Wanda Zabłocka (1900-1978) s. 126-128; Rutkowski L., Michno-Zatorska Z.: Jan Wojciech Zabłocki (1894-1978) s. 128-130.

15. BURDA Bogumiła: Okres rewolucji 1917 roku w Rosji w programach i podręcznikach szkolnych do historii w Polsce powojennej (do połowy lat dziewięćdziesiątych). W: Europa Środkowo-Wschodnia. Ideologia, historia a społeczeństwo. Księga poświęcona pamięci profesora Wojciecha Peltza. Red. nauk. Jarosław Dudek, Daria Janiszewska, Urszula Świderska-Włodarczyk. Zielona Góra 2005 s. 113-130.

16. DROGI i bezdroża polskiej oświaty w latach 1945-2005. Próba wybiórczo-retrospektywnego spojrzenia. Red. nauk. Czesław Kupisiewicz; przy współpr. Małgorzaty Kupisiewicz i Renaty 
Nowakowskiej-Siuta. Warszawa 2005 Elipsa ss. 198, nlb. 2, sum. Komitet Prognoz „Polska 2000 Plus" przy Prezydium PAN, Wyższa Szkoła Umiejętności Pedagog. i Zarządzania.

Materiały z konferencji, Warszawa 10 II 2005 r.

17. DWORAKOWSKA-MARINOW Dominika: Dzieje szkolnej recepcji tekstów Mikołaja Reja. W: Mikołaj Rej - w pięćsetlecie urodzin. Praca zbiorowa. Cz. 2. Pod red. Jana Okonia. Łódź 2005 s. $277-288$.

18. DZIELNOŚĆ i troska. Studia dedykowane Profesor Eugenii Malewskiej. Red. nauk. Alicja Kicowska, Zbigniew Kwieciński. Olsztyn 2005 Wydaw. Uniw. Warmińsko-Mazurskiego ss. 374, nlb. 2.

Z treści: Kicowska A.: Sylwetka prof. zw. dr hab. Eugenii Malewskiej s. 13-18; Kicowska A.: Historia „kortowskiej” pedagogiki (1966-1999) s. 33-48; Łapiński Eugeniusz: Pięć lat Wydziału Pedagogiki i Wychowania Artystycznego (1999-2004) Uniwersytetu Warmińsko-Mazurskiego w Olsztynie s. 49-56; Pulińska Urszula: Edukacja nauczycieli w Wyższej Szkole Rolniczej i Akademii Rolniczo-Technicznej w Olsztynie s. 77-85; Gaber Mariola: Współpraca Instytutu Oświaty Rolniczej z Wyższą Szkołą Pedagogiczno-Techniczną w Eindhoven w Holandii w latach 1992-1994, w ramach projektu „Olsztaut” s. 87-92; Kabzińska Łucja: Stan i potrzeby edukacji rolniczej w ujęciu Stronnictwa Ludowego (1931-1939) s. 125-148; Suchowiecka Anita: Oczyma wyobraźni mojej... Historia życia codziennego rodzin warmińskich na przełomie XIX i XX wieku s. 151-162; Radziszewska Maria: Etos polskiego nauczyciela na Warmii i Mazurach w latach 1929-1939 s. 163-170; Puliński Andrzej: Uczniowie i nauczyciele w nielegalnych organizacjach politycznych na Warmii i Mazurach w latach 1945-1956 s. 171-182.

19. EDUKACJA w społeczeństwie wielokulturowym. Pod red. Kazimierza Rędzińskiego. Częstochowa 2004 Wydaw. Akad. im. Jana Długosza ss. 296, il. (Prace Naukowe Akademii im. Jana Długosza w Częstochowie. Seria Pedagogika. T. 13).

Z treści: Lipiec Wojciech: Wspomnienie o Januszu Lipcu [1924-1992] s. 11-19; Rędziński K.: Szkolnictwo żydowskie w Częstochowie w latach 1868-1914 s. 23-41; Paszkowski Wiesław: Powstanie szkolnictwa jidyszystycznego w Polsce s. 43-56; Lapot Mirosław: Żydowska opieka nad dzieckiem sierocym w Galicji w XIX i na początku XX w. (do 1914 r.) s. 57-73; Puchowska Małgorzata: Tematyka żydowska na scenie jezuickiego teatru szkolnego w Chyrowie s. 75-84; Walasek Stefania: Relacje polsko-litewskie i polsko-białoruskie na przykładzie szkolnictwa w województwach pólnocno-wschodnich II Rzeczypospolitej s. 85-91; Meducka Marta: Biblioteki Polskiej Macierzy Szkolnej w Kieleckiem w latach 1918-1939 s. 93-105; Szczygiel Mirosława: Zadania i cele pomocy społecznej w II Rzeczypospolitej na przykładzie miasta Częstochowy (wybrane aspekty) s. 107-114; Suchmiel Jadwiga: Emancypacja naukowa kobiet w uniwersytetach w Krakowie i we Lwowie do roku 1939 s. 115-123; Domagalska Sylwia: Kształtowanie się kultury robotniczej w częstochowskiej dzielnicy Raków s. 125-135; Grygajtis Krzysztof: Etos sąsiedztwa. Mniejszości narodowe w III Rzeczypospolitej (Ukraińcy, Lemkowie, Niemcy, Białorusini, Litwini) s. 139-182; Gawlik Stanisław: Historyczna i kulturowa przestrzeń kolędy s. 235-242; Pawelec Lidia: Wielokulturowy wymiar kapliczek i krzyży przydrożnych s. 243-252.

Rec.: Chodakowska Janina, Rozpr. Dziej. Ośw. T. 44: 2005 s. 243-246.

20. ERGETOWSKI Ryszard: Silesiaca. Biblioteki, studenci, uczeni. Wyboru dokonała i wstępem opatrzyła Ewa Libura. Wrocław 2005 Wydaw. Uniw. Wrocławskiego ss. 394, nlb. 2, il., sum., Zsfg. (Acta Universitatis Wratislavienis. No 2625).

Treśc: Doktorat Chrystiana Fryderyka Paritiusa s. 35-46; Studia Wacława A[leksandra] Maciejowskiego na Uniwersytecie Wroclawskim s. 47-70; Studia Józefa Kazimierza Plebańskiego i pierwsze lata jego nauczycielskiej pracy s. 71-129; Nieznany fragment rozprawy Józefa Kazimerza Plebańskiego „Przegląd pedagogiczny” s. 130-135; Epistolarna spuścizna Józefa Kazimerza Plebańskiego s. 136-144; Związi Bronisława Kąsinowskiego z wrocławskim i krakowskim uniwersytetem s. 190-212; Zapomniane „adresy” wrocławskich studentów s. 213-219; Zamierzona habilitacja i niedoszły lektorat Adama Mahrburga s. 248-262; Bronisław Trzaskowski - kandydat do objęcia katedry slawistycznej na Uniwersytecie Wroclawskim s. 263-288; Wincenty Kraiński - lektor języka polskiego na Uniwersytecie Wrocławskim (1851-1880) s. 289-318; Raphael 
Löwenfeld als Polonist in seiner Breslauer Zeit (1876-1887) s. 319-334; Habilitacja Rudolfa Abichta na Uniwersytecie Wrocławskim s. 335-346; Stan badań nad wrocławską slawistyką (do 1945 roku) s. 347-364.

21. FARUGA Andrzej: Z kart historii szkolnictwa rolniczego. Kalendarz Cieszyński. [R. 22]: 2006 [dr.:] 2005 s. 47-53.

Na Śląsku Cieszyńskim, XIX-XX w.

22. GOLYGOWSKA Wioletta: Problem personifikacji procesu dziejowego w podręcznikach do nauczania historii. Pr. Uczes. Stud. Dokt. [T.] 7: Historia: 2004 s. 53-57.

23. GÓRECKA Halina: System szkolny w Polsce w latach 1973-1993. Szkolnictwo zawodowe, specjalne i wyższe. Olsztyn 2005 Wydaw. Uniw. Warmińsko-Mazurskiego ss. 227, nlb. 1.

24. GÓRECKI Jan: Wyższe szkolnictwo rolnicze w Polsce. Rys historyczny i stan obecny. Polish higher education in agricultural sciences. Historical review and present status. Warszawa 2004 Wydaw. Fundacji „Rozwój SGGW” ss. 24, il.

Tekst równol. pol., ang.

25. GRUNDBOECK Marian: Myśli o nauce i pracownikach naukowych; Addendum: dzieje polskich uczelni weterynaryjnych i Państwowego Instytutu Weterynaryjnego w Puławach. Wyd. 2 uzup. Puławy 2005 Marian Grundboeck ss. 171, nlb. 2, il.

Wyd. 1. 1998.

26. HERDEN Elżbieta: Książki do nauki języka polskiego w repertuarze wydawców śląskich okresu oświecenia (1750-1820). W: Historia książki na terenach pogranicza i jej rola w kształtowaniu społeczeństw wielokulturowych. Materiały z polsko-niemieckiej konferencji bibliotekarzy, Zielona Góra, 21-22 kwietnia 2005. Red. Katarzyna Raczyńska. Zielona Góra 2005 s. 19-30.

27. HISTORIA i stan obecny katedr i zakładów fizjologii zwierząt w obszarze nauk rolniczych i weterynaryjnych (1945-2005). Pod red. Tadeusza Krzymowskiego. Olsztyn 2005 Wydaw. Uniw. Warmińsko-Mazurskiego ss. 384, il.

Z treści: Placówki szkolnictwa wyższego s. 19-219.

28. HOFFMANN Gabriela: Zarys szkolnictwa i środowiska Rakoniewickiego. Rakoniewice-Grodzisk Wlkp. 2005 Zakł. Usług Poligraf. Iwona Wałkiewicz ss. 409, il.

XVII-XX w.

29. JAGIELLO Zdzisław: Piechota i szkolnictwo piechoty Wojska Polskiego w pierwszej połowie XX wieku, stan i postulaty badań nad ich dziejami. W: Źródła w badaniach historii wojskowej. VII Ogólnopolskie Forum Historyków Wojskowości, Siedlce, 17-18 września 2003 r. Red. nauk. Kazimierz Pindel. Torun 2004 s. 117-122. Inst. Historii Akad. Podlaskiej, Stow. Historyków Wojskowości.

30. KALINOWSKI Marian: Otwockie szkolnictwo do roku 1945. Rocz. Maz. T. 17: 2005 s. 65-76.

Od 1905.

31. KOJOKOE Jerzy: Polska myśl społeczna o wychowaniu w latach 1900-1950. Warszawa-Tyczyn 2005 Pol. Tow. Religioznawcze; Wyższa Szkoła Społ.-Gosp. ss. 175.

32. KOZACZYŃSKA Beata: Sprawozdanie z konferencji naukowej na temat: „Etos wychowania w dziejach narodu polskiego", Augustów, 23-24 maja 2005 roku. Prz. Hist.-Ośw. R. 48: 2005 nr 3/4 s. 299-303. 
33. KRUSZEWSKI Tomasz: Udział Pomorskiego Towarzystwa Opieki nad Dziećmi w Toruniu w działaniach społecznych na terenie miasta w latach 1918-1949. Rocz. Tor. [T.] 32: 2005 s. 111-132, sum., Zsfg.

34. KUSTRA Czesław: Działalność edukacyjna Towarzystwa „Powściągliwość i Praca” w latach 1898-1949. Olsztyn 2005 Wyższa Szkoła Informatyki i Ekonomii TWP ss. 208, nlb. 4, sum.

35. KWIATKOWSKI Stefan M.: Z kart historii „pedagogiki pracy”. Prz. Hist.-Ośw. R. 48: $2005 \mathrm{nr} \mathrm{3/4} \mathrm{s.} \mathrm{37-49.}$

Dzieje przedmiotu akademickiego od $1972 \mathrm{r}$.

36. LUKASIK Lidia: Szkoły, ich absolwenci i nauczyciele. W: Chotcza wczoraj, dziś, jutro. Praca zbior. pod red. Aliny Skorupskiej-Tomczyk i Władysława Witczaka. Sycyna-Chotcza 2005 s. $129-162$.

37. MACIASZEK Aleksandra: Edukacja i praca kulturalno-oświatowa w Zakładzie Karnym w Głubczycach, w latach 1983-2000. Pr. Uczes. Stud. Dokt. [T.] 6: Pedagogika: 2003 s. 73-86.

38. MALACHOWSKI Ryszard: Średnie szkolnictwo katolickie w Polsce i wybranych państwach europejskich (lata 1945-2000). Zielona Góra 2005 Oficyna Wydawnicza Uniw. Zielonogórskiego ss. 322, nlb. 1, il. Uniw. Zielonogórski.

39. MOŻDŻEŃ Stefan Ignacy: Historia wychowania do 1795 . Kielce-Sandomierz 2005 Wydaw. Diec. ss. 431, nlb. 8, mapy.

40. MULARCZYK Maciej: Szkolnictwo jezuickie - fakty i mity - komunikat. Krak. Studia Matopol. Nr 7: 2003 s. 482-487.

41. NAWROCKI Leon: Szkolnictwo, oświata, nauczyciele regionu grójeckiego w latach 1917-1945. Kielce-Grójec 2005 APLA ss. 255, nlb. 1, il.

42. NIKLEWSKA Jolanta: Guwernantki i nauczycielki-cudzoziemki na ziemiach polskich w XIX i XX w. Ich rola oświatowa i kulturalna. W: Kobiety i młodzież w migracjach. Pod red. Jana E. Zamojskiego. Warszawa 2005 s. 113-122.

43. NOWAK Ewa: Polska młodzież akademicka w Austrii w XIX i XX w. W: Kobiety i młodzież w migracjach. Pod red. Jana E. Zamojskiego. Warszawa 2005 s. 399-419.

44. OCALIĆ od zapomnienia. Historia szkół na terenie gminy Lutocin. Pod red. Danuty Pekról [i in.]. Lutocin-Żuromin 2005 CourieR Firma Poligraficzna ss. 391, il.

45. PASTUSZKA Stefan Józef: Wkład ruchu ludowego w rozwój oświaty. W: Historia i współczesność ruchu ludowego. Materiały z sesji popularnonaukowej, która odbyła się 9 września w Kielcach z okazji 110 rocznicy powstania zorganizowanego, politycznego ruchu ludowego. W oprac. red. Stanisława Durleja. Kielce 2005 s. 41-58.

46. ROSTKOWSKI Zbigniew: Szkolnictwo w dobrach starowiejskich w XVIII i XIX wieku. Rocz. Bial.-Podl. T. 13: 2005 s. 81-98.

Stara Wieś na Podlasiu.

47. RUSINKO Elżbieta: Szkolnictwo średnie w Jarosławiu w latach 1884-1939. Aspekty ekonomiczno-socjalne. Rocz. Przem. R. 41: 2005 z. 4 s. 57-70.

48. SADKOWSKA Katarzyna: Recepcja szkolna i uniwersytecka twórczości Friedricha Hebbla w Galicji (1890-1939). Pam. Liter. R. 95: 2004 z. 2 s. 187-206. 
49. SCHILLER Joanna: Międzynarodowa Konferencja „Uniwersytety i inteligencja w Rosji (koniec XIX - początek XXI wieku)", Rostów nad Donem, 8-10 czerwca 2005 r. Rozpr. Dziej. Ośw. T. 44: 2005 s. 249-253.

50. SOLIŃSKA Małgorzata: „Nie masz nic milszego ponad ciągnący żeński pensjonat...” (Obraz pensji we wspomnieniach pensjonarek). Litteraria. [R.] 34: 2004 s. 33-47.

XIX-XX w.

51. SPOTKANIA popiołkowskie. Pod red. Dariusza Rotta i Tadeusza Sławka. Katowice 2005 Stow. Przyj. Uniw. Śląskiego; Fund. „Pallas Silesia” ss. 114, tabl. 6, il. Stow. Przyj. Uniw. Śląskiego; Fund. „Pallas Silesia”. (Uniwersytet Śląski Wczoraj, Dziś, Jutro).

Materiały z pierwszego i drugiego spotkania, które odbyły się 18 XI 2003 r. oraz 25 XI 2004 r.

Z treści: Baranowska Teresa: Korzenie szkolnictwa średniego w Katowicach s. 35-44; Puchała Stanisław: Rola Kościoła katolickiego w tworzeniu środowiska akademickiego na Śląsku s. 45-53; Salamon Maciej: O pożytku z „peregrynacji akademickich” (nie tylko Kraków i Katowice) s. 62-73; Lityński Adam: Początki Wydziału Prawa i Administracji Uniwersytetu Śląskiego s. 74 89; Dłotko Tadeusz: Rola Uniwersytetu Śląskiego w rozwoju matematyki na Górnym Śląsku s. 90-96.

52. SURDACKI Marian: Edukacyjno-opiekuńcze funkcje cechów urzędowskich w XV-XVIII wieku. Rozpr. Dziej. Ośw. T. 44: 2005 s. 7-48, sum.

Urzędów, pow. kraśnicki.

53. ŚREDNIAWA Bronisław, Pawlikowska-Brożek Zofia: Polskie podręczniki historii fizyki, astronomii i matematyki. Analecta. R. 14: 2005 z. 1/2 s. 99-125, sum.

Od XIX w.

54. WESOŁOWSKA Sylwia: Z dziejów szkolnictwa w gminie Malechowo do 1945 roku. W: Historia i kultura Ziemi Sławieńskiej. T. 4: Gmina Malechowo. Red. Włodzimierz Rączkowski, Jan Sroka. Sławno-Gdynia 2005 s. 179-195.

55. WROCEAWSKIE szkoły. Historia i architektura. Pod red. Marii Zwierz. Wrocław 2004 Muzeum Architektury we Wrocławiu ss. 255.

Rec.: Schiller Joanna, Rozpr. Dziej. Ośw. T. 43: 2004 s. 235-237.

56. WRÓBLEWSKI Maciej: Proza niefikcjonalna w edukacji polonistycznej ucznia szkoły średniej (1855-1939). Toruń 2003 Adam Marszałek ss. 294. (Biblioteka Filologiczna).

57. ZWIĄZEK Jan: Z dziejów nauczania religii w diecezji częstochowskiej (1925-2005). W: Jubileusz 80-lecia działalności katechetycznej w Kościele Częstochowskim (1925-2005). Red. Norbert Pikuła. Kraków-Częstochowa 2005 s. 23-67.

\section{Okres do 1795 roku}

58. ACHREMCZYK Stanisław: Myśl uniwersytecka w Prusach. W: Kardynał Stanisław Hozjusz (1504-1579). Osoba, myśl, dzieło, czasy, znaczenie. Praca zbior. pod red. Stanisława Achremczyka, Jana Guzowskiego i Jacka Jezierskiego. Olsztyn 2005 s. 15-41.

59. BOGDAN Izabela: Muzyka w szkołach łacińskich Królewca w XVI i pierwszej połowie XVII wieku. Kom. Mazur.-Warm. [R. 49]: 2005 nr 1 s. 37-55, Zsfg. 
60. BRODNICKI Mariusz: Hermeneutyczny model pijarskiego teatru szkolnego w koncepcji Stanisława Konarskiego na przykładzie tragedii „Otto” Corneille’a. Rocz. Gdań. T. 65: 2005 z. 1/2 s. $137-149$, sum.

61. BURZYŃSKA-KAMIENICKA Anna B.: „Jużem w Oławie, dojadęć i Brzega...”. Śląskie toponimy w dawnych podręcznikach do nauki języka polskiego (XVII-XVIII w.). Rozpr. Komis. Jęz. [T.] 30: 2004 s. 85-88.

62. CHACHAJ Jacek: Lacińskie szkoły parafialne na terenie metropolii lwowskiej w epoce nowożytnej. Lublin 2005 Tow. Nauk. KUL ss. 229, nlb. 2, il., sum. Tow. Nauk. KUL. (Prace z Historii Szkolnictwa w Polsce. T. 13) (Źródła i Monografie. [T.] 290).

63. CHACHAJ Marian: Edukacja synów, wnuków i prawnuków Mikołaja Reja. W: Mikołaj Rej z Nagłowic w pięćsetną rocznicę urodzin. Pod red. Waldemara Kowalskiego. Kielce 2005 s. 257-273.

64. DANIELAK-CHOMAMAĆ Małgorzata: Kształcenie młodzieży zakonnej w Białej - studia konwenckie franciszkanów-reformatów. Rocz. Bial.-Podl. T. 13: 2005 s. 99-120.

XVII-XIX w.

65. FLAGA Jerzy: Nauczanie prawa w studiach zakonnych w Polsce w XVII i XVIII w. Prawo-Administracja-Kościól. $2000 \mathrm{nr}$ 2/3 s. 85-99, Zsfg.

66. GARAPICH Michał P.: Jak to Kochanowski prezesem był... O pierwszym polskim stowarzyszeniu za granicą. Rocz. PTN na Obczyźnie. R. 47: 2003/2004 [dr.:] 2005 s. 379-383.

Stowarzyszenie polskich studentów założone 18 VII 1554 r. przez Jana Kochanowskiego w Padwie.

67. GERLIC Henryk: Siedemnastowieczne fundacje na rzecz gimnazjum opawskiego i edukacji młodzieży gliwickiej. Rocz. Muz. Gliw. T. 18: 2003 [dr.:] 2005 s. 31-50, sum., Zsfg.

68. HERBA Agnieszka: O uzdrowieniu studenta z rozpusty. W: Klasztorne ośrodki piśmiennictwa i kultury w krajach słowiańskich. Red. Jordanka Georgiewa-Okoń, Jan Stradomski; wstęp Wanda Stępniak-Minczewa. Kraków 2005 s. 61-68.

69. HOCHLEITBER Janusz: Twórcy świetności Gimnazjum Elbląskiego w XVI-XVII wieku. W: Życie codzienne na dawnych ziemiach pruskich. Krzewienie wiedzy. Praca zbior. pod red. Stanisława Achremczyka. Olsztyn-Olsztynek 2005 s. 36-47.

70. INSTRUKCJA dla nauczyciela szkoły parafialnej w Dobromilu z 1763 r. Przyczynek do dziejów oświaty staropolskiej. [Wyd.] Roman Pelczar. Nasza Przeszłość. [T.] 104: 2005 s. 259-266.

71. KACZMAREK Krzysztof: Szkoły i studia polskich dominikanów w okresie średniowiecza. Poznań 2005 Inst. Hist. UAM ss. 605, sum. UAM. (Publikacje Instytutu Historii. [T.] 67).

XIII-XV w.

72. KASABU氏A Tadeusz: Posiłki w diecezjalnym seminarium duchownym w Wilnie u schyłku XVIII wieku. Wiad. Kośc. Archidiec. Białost. R. 11: 2002 nr 1 s. 215-223.

73. KASABUŁA Tadeusz: Szkoła parafialna w Goniądzu w czasach Komisji Edukacji Narodowej (1773-1794). Wiad. Kośc. Archidiec. Bialost. R. 11: 2002 nr 4 s. 218-228.

74. KOWALSKI Maciej: Kształcenie wojskowe magnatów w XVII wieku w świetle instrukcji rodzicielskich. Studenckie Zap. Hist. Z. 2: 2005 s. 63-74. 
75. KUBACZ Adam: Szkolnictwo na Śląsku Cieszyńskim do końca XVII w. Śl. Kw. Hist. Sobótka. R. 60: $2005 \mathrm{nr} 2$ s. 125-156, Zsfg.

Od XVI w.

76. KUBACZ A.: Szkolnictwo na Śląsku Cieszyńskim w pierwszej połowie XVIII w. Śl. Kw. Hist. Sobótka. R. 60: 2005 nr 3 s. 295-315, Zsfg.

77. KUPISZ Anna: Pedagodzy kolegium jezuickiego w Lublinie w XVI i XVII wieku. Rocz. Nauk Spot. T. 33: 2005 z. 2 s. 135-148, sum.

$\mathrm{W}$ aneksie spis pedagogów.

78. LESZCZYNSKI Hugo: Wychowanie, studia i szkoły w klasztorach cysterskich. W: Grudziądz miastem Chrystiana. Materiały posesyjne z II sympozjum „Grudziądz miastem Chrystiana”, 4.12.1998 r. Red. Krystyna Zielińska-Melkowska. Grudziądz 2002 s. 10-18.

79. MIĘDZY barokiem a oświeceniem. Edukacja, wykształcenie, wiedza. Praca zbior. pod red. Stanisława Achremczyka. Olsztyn 2005 OBN ss. 345, nlb. 1, il. Tow. Nauk., Ośr. Badań Nauk. im. Wojciecha Kętrzyńskiego. (Rozprawy i Materiały. Nr 226).

Z treści: Achremczyk S.: Wstęp s. 5-6; Poraziński Jarosław: „Statysta głęboki”. Kilka uwag o erudycji staropolskich polityków s. 7-13; Puchowski Kazimierz: Przemiany w szkolnictwie zakonnym Rzeczypospolitej czasów saskich s. 14-23; Dumanowski Jarosław: Edukacja, prawo i wydatki. Miejsce wykształcenia w strategiach życiowych szlachty wielkopolskiej w XVIII wieku s. 24-30; Rok Bogdan: Rola podróży w ksztaltowaniu obrazu świata w mentalności polskiej XVIII wieku s. 31-37; Kamecka Małgorzata: „Po naukę świata i ludzi”. O zagranicznej edukacji Polaków czasów saskich s. 38-48; Roszak Stanisław: „W realnej postaci cudze kraje nawiedzac ?" Podróź jako edukacyjny dylemat czasów saskich s. 49-54; Jaroszewicz-Pieresławcew Zoja: Ideał biblioteki ziemiańskiej w siedemnastowiecznym dziele Jakuba Kazimierza Haura a rzeczywistość s. 55-62; Żukowska Justyna: Kalendarze Jana Poszakowskiego [1684-1757] jako źródło edukacji historycznej s. 111-121; Obremski Krzysztof: Czy Jakub Kazimierz Rubinkowski faktycznie był erudytą ? (rekonesans) s. 122-133; Kowalczyk Małgorzata Ewa: Wiedza hydrograficzna w świetle polskiego piśmiennictwa geograficznego XVIII wieku s. 138-147; Krawczyk Antoni: Polskie inspiracje w programach dydaktycznych Akademii Kijowsko-Mohylańskiej s. 148-160; Wiślicz Tomasz: Jak nauczyć analfabetę? Metodologiczne problemy duszpasterstwa katolickiego w Rzeczypospolitej XVIII wieku s. 161-171; Hanczewski Paweł: Amatorzy i zawodowcy. Edukacja dyplomaty w XVIII wieku s. 172-176; Achremczyk S.: Jana Drewsa dystrakcje dla pobożnych i ciekawych świata s. 181-190; Łysiak-Łątkowska Anna: O dzieciństwie w Polsce w XVIII wieku. Zarys problematyki s. 191-209; Jakuboszczak Agnieszka: Myśli o wychowaniu w korespondencji Barbary Sanguszkowej s. 210-217; Bohuszewicz Paweł: Bez ciała, woli i jaźni: o ukrytym dydaktyzmie polskiego Romansu czasów saskich (Elżbieta Drużbacka, 'Historia Ortobana") s. 218-244; Kiełbik Jerzy: Wladze miast warmińskich i ich wykształcenie w XVI-XVIII wieku s. 245-249; Czeppe Maria: Czy dobrze być królewną i królewiczem? Dzieciństwo dwojga naturalnych dzieci Stanisława Augusta s. 250-259; Wyszomirska Monika: Edukacja trybunalska - czyli „Punkta IMCPanu Szwykowskiemu susceptantowi pro memoria dane” 22 IV 1745 s. 280-287; Wolański Filip: Uczelnie Europy Zachodniej w opinii autorów polskich podręczników geograficznych w XVIII wieku s. 310-315; Szorc Alojzy: Warmińskie fundacje naukowe do końca XVIII wieku s. 316-319; Bogdan Danuta: Próby zdyscyplinowania studentów Uniwersytetu Królewieckiego w XVI-XVIII wieku s. 320-332; Makarczyk Irena: Kanonik warmiński Jan Preuck (1575-1631) i jego fundacja szkolna w Rzymie. [W aneksie: własnoręczne uwagi Jana Preucka odnośnie fundacji] s. 333-344.

80. MILIK Katarzyna, Srogosz Tadeusz: Uczniowie lekarscy - stypendyści miast królewskich u schyłku I Rzeczypospolitej. W: Z dziejów Polski XIX i XX wieku. Księga jubileuszowa ofiarowana profesorowi Ryszardowi Szwedowi. Red. nauk. Tadeusz Dubiecki, Tadeusz Panecki. Częstochowa 2004 s. 43-60.

81. OŻÓG Krzysztof: Uczeni w monarchii Jadwigi Andegaweńskiej i Władysława Jagielly (1384-1434). Kraków 2004 PAU ss. 404, sum. PAU. (Rozprawy Wydziału Historyczno-Filozoficznego. T. 104).

Rec.: Śnieżyńska-Stolot Ewa: Na marginesie ksiąziki.. Kw. Hist. Nauki i Techn. R. 50: 2005 nr 3/4 s. 253-262. 
82. PANIC Idzi: Sieć szkolna w dekanacie gliwickim w drugiej połowie XVII wieku. (Z badań nad dziejami szkolnictwa w regionie gliwickim w czasach wczesnonowożytnych). Rocz. Muz. Gliw. T. 18: 2003 [dr.:] 2005 s. 51-73, sum., Zsfg.

83. PIRAMOWICZ Grzegorz: Powinności nauczyciela oraz wybór mów i listów. Oprac. i wstępem opatrzyła Kamilla Mrozowska. Wrocław-Warszawa 2005 Zakł. Nar. im. Ossolińskich; we współpr. z De Agostini Polska ss. CXIII, nlb. 1, 232, nlb. 1. (Skarby Biblioteki Narodowej).

84. PTASZYŃSKI Maciej: Pietas i sapientia? Wykształcenie pastorów w księstwach zachodniopomorskich w latach 1560-1618. Odrodzenie i Reformacja w Polsce. T. 49: 2005 s. 35-61, Zsfg.

85. REBETA Jerzy: Relativisation des critères de la hièrarchisation des sciences et ses consquences pour la valorisation des sciences socials ù l'Universitè de Cracovie au commencement du XVe siècle. Acta Mediaevalia. T. 18: 2005 s. 399-410, streszcz.

86. ROK Bogdan: Staropolskie kalendarze profesorów zamojskich z przełomu XVII i XVIII wieku. Res Historica. T. 20: 2005 s. 173-180.

87. ROSZAK Stanisław: Kolokwium z okazji 250 rocznicy założenia Akademii Stanisława Leszczyńsiego, Nancy, 17-19 września 2001 roku (Colloque des 250 ans de l'Académie de Stanislas). Klio. [R. 2]: $2002 \mathrm{nr} 2$ s. 225-228.

88. SIEMIANCZUK Albina: Edukacja w Wielkim Księstwie Litewskim. W: Poszukiwanie wspólnych korzeni kulturowych Białorusi i Polski. Materiały z konferencji międzynarodowej, Wigry, 6-8 czerwca 2005 r. (Praca zbiorowa). Suwałki 2005 s. 6-16, 88-99.

89. SPYRA Janusz: Adam Wacław Paczyński hrabia z Tęczyna i początki konwiktu św. Trójcy dla młodzieży szlacheckiej w Cieszynie. Ziemia Śl. T. 6: 2005 s. 189-205.

Lata 1650-1727.

90. STUDENSKI Marek: Wizja wychowania w „Ustawie szkolnej Towarzystwa Jezusowego" z 1599 r. w kontekście obecnej sytuacji wychowawczej. W: Towarzystwo Jezusowe na Śląsku Cieszyńskim. Studium ekumeniczne. Praca zbior. pod red. Józefa Budniaka i Karola Mozora. Kraków 2005 s. $63-76$.

91. TERNES Jerzy: Ekscesy studenckie w siedemnastowiecznym Zamościu. Res Historica. T. 20: 2005 s. $133-140$.

92. WIELGUS Stanisław: Zachodnia i polska nauka średniowieczna - encyklopedycznie. Płock 2005 Płocki Inst. Wydawniczy ss. 320, il.

93. WIELKIE dzieło reformy wychowania - ksiądz Stanisław Konarski (1700-1773). Materiały z sesji naukowej. Wstęp i oprac. Teresa Gumuła. Ostrowiec Świętokrzyski 2005 Stow. na Rzecz Rozwoju Wyższej Szkoły Biznesu i Przedsiębiorczości ss. 89.

Ostrowiec Świętokrzyski, 22 III 2004 r.

Treść: Gumuła T.: Wprowadzenie s. 5; Stencel Ewa: Regionalne Stowarzyszenie im. Stanisława Konarskiego w Ostrowcu Świętokrzyskim s. 7-8; Poznański Karol: Poglądy i działalność pedagogiczna Stanisława Konarskiego s. 9-19; Meissner Andrzej: Stanisław Konarski w polskiej literaturze historyczno-pedagogicznej s. 21-30; Piwek Jerzy: Warunki życia ludności wiejskiej na Kielecczyźnie w XVIII wieku s. 31-34; Majewski Stanisław: Wychowanie patriotyczno-obywatelskie w myśli pedagogicznej Stanisława Konarskiego s. 35-37; Gumuła T.: Wychowanie nauczycieli w ujęciu Stanisława Konarskiego s. 39-43; Firlej Waldemar: Wkład ks. Stanisława Konarskiego w dzieło reformy wymowy i kaznodziejstwa w Polsce s. 45-50; Gumuła T., Majewski S.: Stanisław Konarski jako prekursor pedagogiki porb́wnawczej w Polsce s. 51-54; Jadach Jan, Lojek Anna: 
Stanisław Konarski - i imienia Stanisława Konarskiego - wprowadzenie do tematu recepcji dorobku Stanisława Konarskiego s. 55-62 Stanisław Hieronim Konarski - jego życie i działalność (bibliografia) s. 63-88.

94. WOJAKOWSKI Józef: Księgozbiory członków Komisji Edukacji Narodowej zamieszkałych w Warszawie. Rocz. Bibliot. R. 49: 2005 s. 375-382, sum.

95. WOLAŃSKI Filip: Osiemnastowieczne podręczniki geograficzne jako źródło historyczne. W: Causa creandi. O pragmatyce źródła historycznego. Pod red. Stanisława Rosika i Przemysława Wiszewskiego. Wrocław 2005 s. 533-538.

96. WÓJCIK Marek L.: Próba utworzenia Uniwersytetu we Wrocławiu w roku 1505 . Wrocław 2005 Gajt ss. 28, nlb. 4, il.

Toż w jęz. ang.: An attempt to create the University of Wroclaw in the year 1505 . Trans. Piotr N. Galik. Wrocław 2005.

97. WRÓBEL-LIPOWA Krystyna: Relacje Konstancji Zamoyskiej [1742-1797] z jej dorastającymi dziećmi. Res Historica. T. 20: 2005 s. 199-207.

Aleksandrem Augustem, Stanisławem Kostką i Anną (po zamąż́ójjściu Sapieżyną).

98. ZAHAJKIEWICZ Marek: Kościelne zbiory biblioteczne średniowiecznej Polski źródłem do badań nad wykształceniem duchowieństwa. Acta Mediaevalia. T. 18: 2005 s. 421-432, Zsfg.

99. ZDANEK Maciej: Szkoły i studia dominikanów krakowskich w średniowieczu. Warszawa 2005 Neriton; IH PAN ss. 231, nlb. 2, sum.

100. ZONTA Claudia A.: Schlesische Studenten an italienischen Universitäten. Eine prosopographische Studie zur frühneuzeitlichen Bildungsgeschichte. Köln-Weimar-Wien 2004 Böhlau ss. X, 542. (Neue Forschungen zur schlesischen Geschichte. Bd. 10).

Rec.: Jurek Tomasz, Rocz. Hist. R. 71: 2005 s. 294-297.

101. ŻOLALŹ-STRZELCZYK Dorota: The child in the Polish medieval family. Quaestiones Medii Aevi Novae. Vol. 9: 2004 s. 27-64.

\section{Okres $1795-1918$}

102. ADAMCZYK Mieczysław: Szkoły obce w edukacji Galicjan. Cz. 1. Kraje Korony Węgierskiej. Warszawa 2003 Rytm; Węgierski Inst. Kultury w Warszawie ss. 459, nlb. 1, il.

Rec.: Miąso Józef, Rozpr. Dziej. Ośw. T. 44: 2005 s. 226-228.

103. ADAMEK Irena: Wkład teoretyków i praktyków obcych i polskich w rozwój badań psychologicznych nad dzieckiem. Annales APC. Folia 29: Studia ad Institutionem et Educationem Pertinentia. [T.] 1: 2005 s. 13-21, abstr.

Na przelomie XIX i XX w.

104. ALEKSIEWICZ Anna: Spór Karola Cieszewskiego, redaktora pisma „Czytelnia dla Młodzieży", z Dyrekcja Policji we Lwowie - w świetle zachowanẹ korespondençji. Rocz. Bibliot. R. 49: 2005 s. 277-285, Zsfg.

W l. 1860-1861.

105. BŁASZKOWSKI Marcin: Centrum konfirmacyjne w Wilkowicach. Przyj. Ludu. [R. 19]: 2004 [dr.:] 2005 z. 2 s. 13-14.

Punkt spotkań młodzieży z diaspory niemieckiej w Wielkopolsce w końcu XIX w. 
106. BŁAŻEJEWSKA Joanna: Galicyjskie „Muzeum” wobec kształcenia literackiego w gimnazjach (1885-1918). W: Prasa dawna i współczesna. Praca zbiorowa. Cz. 5. Pod red. Bogumiły Kosmanowej. Poznań 2004 s. 33-49.

107. BOGUS Marzena: Poglądy Jerzego Kotuli [1855-1889] na rolę oraz zadania polskich szkół i nauczycieli na Śląsku w świetle korespondencji z Józefem Ignacym Kraszewskim i Władysławem Bełzą. Ziemia Śl. T. 6: 2005 s. 206-225.

108. CHRZĄSZCZ Czesław: „Mniej senzacji, a więcej rozwagi!”. Pozaszkolne formy pracy wychowawczej katechetów galicyjskich szkół średnich w latach 1890-1918. Kraków-Czulice 2005 Parafia Rzymskokatolicka św. Mikołaja ss. 138, il. (Bibliotheca Collectaneae Historicae. T. 8).

109. DZIENIAKOWSKA Jolanta: Książka i buty dla nauczyciela... czyli kwestie organizacyjne pierwszego kursu pedagogicznego departamentu wyznań religijnych i oświecenia publicznego (1917/1918). Prz. Hist.-Ośw. R. 48: 2005 nr 1/2 s. 141-150.

110. EPSZTEIN Tadeusz: Nauczanie domowe dzieci na ziemiach polskich w XIX i na początku XX wieku. Konferencja naukowa - Pieczyska 18-19 września 2003 r. Maz. Studia Hum. R. 10: $2004 \mathrm{nr} 1 / 2$ s. $282-284$.

111. FRAS Zbigniew: [Józef] Wybicki autorem podręczników szkolnych. Rocz. Mazurka Dąbrowskiego. Nr 5/6: 2000/2001 [dr.:] 2001 s. 105-107.

M.in. „Początki mitologii do użytku w szkołach” (Wrocław 1803) i „Początki geografii politycznej” (Wrocław 1804).

112. GALEK Czesław: Myśl pedagogiczna Bolesława Prusa na tle pozytywizmu polskiego. Zamość 2005 Wyższa Szkoła Zarządzania i Admin. Centrum Badawczo-Szkoleniowe ss. 378.

113. GIZA Jerzy: Sądeccy gimnazjaliści - bohaterowie organizacji „Wolność”. Almanach Sqdec. R. 14: $2005 \mathrm{nr}$ 1/2 s. 87-100.

Z 1. 1914-1918 (organizacja powołana w 1916 r.).

114. GOCŁAWSKA-HRYCHORCZUK Anna: Jan Cynarski-Krzesławski w walce o polską szkołę w Królestwie Polskim (1916-1918). Acta UL. Folia Historica. [Vol.] 79: Studia i szkice z historii XVIII-XIX wieku s. 73-97, sum.

115. HOSZOWSKA Mariola: Siła tradycji, presja życia. Kobiety w dawnych podręcznikach dziejów Polski (1795-1918). Rzeszów 2005 Wydaw. Uniw. Rzeszowskiego ss. 331, nlb. 1.

116. HOSZOWSKA M.: Wizerunek kobiety w lwowskich podręcznikach historii Polski XIX wieku. W: Wielokulturowe środowisko historyczne Lwowa w XIX i XX w. T. 3. Pod red. Jerzego Maternickiego, Leonida Zaszkilniaka. Rzeszów 2005 s. 153-172.

117. JANICKI Arkadiusz: Studenci polscy na Politechnice Ryskiej w latach 1862-1918. T. 1: Rys historyczny. Gdańsk 2005 Wydaw. Uniw. Gdańskiego ss. 318, nlb. 2.

Toż. T. 2: Album Academicum Polonorum (aneks). Gdańsk 2005 ss. 338, nlb. 2.

118. JONCA Magdalena: Enfants terribles. Dzieci złe, źle wychowane w literaturze polskiej XIX wieku. Wrocław 2005 Wydaw. Uniw. Wrocławskiego ss. 494, il., sum. (Acta Universitatis Wratislaviensis. No 2671).

119. KÄMPFERT Hans-Jürgen: Die Gründung der Technischen Hochschule Danzig vor 100 Jahren. Westpreussen-Jahrbuch. Bd. 54: 2004 s. 101-114. 
120. KARLOWSKA Grażyna: Konferencja „Nauczanie domowe dzieci na ziemiach polskich w XIX i na początku XX wieku. Zapatrywania teoretyczne i praktyka", Pieczyska, 18-19 września 2003. Acta Elbingensia. T. 2: 2004 s. 541-543.

121. KARŁOWSKA G. Nawrot Monika: Charakterystyka zbiorowości nauczycieli domowych w Królestwie Polskim w świetle literatury wspomnieniowej i pamiętnikarskiej. Acta UNC. Nauki Hum.-Społ. Z. 365: Pedagogika. [Nr] 23: Historia Wychowania 2004 s. 65-94.

122. KARŁOWSKA G., Nawrot M.: Metody nauczania domowego w rodzinie polskiej w zaborze rosyjskim w XIX i na początku XX wieku. Acta Elbingensia. T. 2: 2004 s. 119-133.

123. KIJAS Artur: Polacy na Uniwersytecie Charkowskim 1805-1917. Poznań 2005 Zakk. Poligraficzny „Grafika" ss. 258, il, sum., res.

124. KOC Adam: Wspomnienia. Oprac. Janusz Mierzwa. Wrocław 2005 Tow. Przyj. Ossolineum ss. 298 , nlb. 2 , tabl. 15.

Wspomnienia działacza sanacji, założyciela OZN, żyjącego w l. 1891-1969, opisujące m.in. dzieciństwo w rodzinie nauczycielskiej w Suwałkach, edukację i udział w strajku szkolnym, studia polonistyczne na UJ.

125. KOZERA Andrzej: Oświata w polskiej myśli politycznej na przełomie XIX i XX wieku. (Do odzyskania niepodległości w 1918 roku). Kielce 2004 Zakł. Poligraficzno-Wydawniczy „U Poety" ss. 66. Inst. Nauk Polit. Akad. Świętokrzyskiej w Kielcach.

126. KRZYWIEC Grzegorz: Rewolta młodych. U źródeł fenomenu kółek samokształceniowych na przełomie 1. 70. i 80. XIX wieku. W: Życie jest wszędzie... Vsjudu Žizn'... Ruchy społeczne w Polsce i Rosji do II wojny światowej. Zbiór materiałów z konferencji 16-17 września 2003 r. Warszawa. Pod red. Anny Brus. Warszawa 2005 s. 293-308.

127. [KRZYŻANOWSKI Jan Kanty]: Szkolnictwo Królestwa Polskiego w okresie paskiewiczowskim w świetle Kroniki Jana Kantego Krzyżanowskiego. Wstęp i oprac. Stefan I. Możdżeń. Częstochowa 2004 Wydaw. Akad. Polonijnej „Educator” ss. 185, il. (Nauczyciel, Praca, Doświadczenie).

Współwyd.: Kronika szkół Królestwa Polskiego po roku 1831 spisana przez Jana Kantego Krzyżanowskiego ...

128. KUDŁA Lucyna: Gimnazjaliści galicyjscy doby autonomicznej. Charakterystyka społeczności. Annales APC. Folia 28: Studia Historica. [T.] 4: 2005 s. 97-113, abstr.

129. LUKASIEWICZ Dariusz: Szkolnictwo w departamencie kaliskim w świetle pruskich tabel szkolnych z 1799 roku. Rocz. Kalis. T. 27: 2001 s. 27-46.

130. MASSALSKI Adam: Nauczyciele geografii i historii szkół średnich męskich rządowych w Królestwie Polskim w latach 1833-1862. W: Z dziejów Polski XIX i XX wieku. Księga jubileuszowa ofiarowana profesorowi Ryszardowi Szwedowi. Red. nauk. Tadeusz Dubiecki, Tadeusz Panecki. Częstochowa 2004 s. 61-104.

131. MIĄSO Józef: Walka o narodową szkołę w Królestwie Polskim w latach 1905-1907 (w stulecie strajku szkolnego). Rozpr. Dziej. Ośw. T. 44: 2005 s. 75-103, sum.

132. MłYNARSKA Henryka: Odnaleziony rękopis Rafała Urbana. Kw. Opol. R. 50: 2004 nr 2/3 s. 131-145.

Dot. przeplatanego wątkami autobiograficznymi tekstu „Szkoła wolności, czyli skromny pomnik nieznanego poety i nieznanego pedagoga", poświęconego przetrwaniu polskości na Opolszczyźnie, autorstwa gawędziarza z Glogówka (1893-1972). Zawiera też tekst utworu. 
133. MOLIK Witold: Kształtowanie się samowiedzy inteligencji polskiej w Wielkim Księstwie Poznańskim w drugiej połowie XIX i na początku XX w. Rocz. Dziej. Spol. i Gosp. T. 65: 2005 s. $105-125$, sum.

134. MROZ Tomasz: Starania Wincentego Lutosławskiego o krakowską katedrę filozofii. $K w$. Hist. Nauki i Techn. R. 50: $2005 \mathrm{nr} 1$ s. 79-94, sum.

$1891 \mathrm{r}$.

135. NAWROT Monika: Rola rodziny i nauczania domowego w utrzymaniu tożsamości narodowej Polaków na terenie zaboru rosyjskiego w drugiej połowie XIX wieku i w początkach wieku XX w świetle pamiętnikarstwa. (Bydgoszcz 2002, s. 323). Annales APC. Cracoviensis. Folia 29: Studia ad Institutionem et Educationem Pertinentia. [T.] 1: 2005 s. 177-183.

Autoreferat. I nagroda w Ogólnopolskim Konkursie Prac Magisterskich z Historii Edukacji im. Profesora Czesława Majorka za rok 2002/2003.

136. NAWROT M.: Rola rodziny w utrzymaniu tożsamości narodowej Polaków na terenie zaboru rosyjskiego w drugiej połowie XIX i początkach wieku XX w świetle literatury wspomnieniowej i pamiętnikarstwa. Acta Elbingensia. T. 1: 2003 s. 51-70.

137. NIEWĘGŁOWSKA Aneta: Średnie szkolnictwo żeńskie w Toruniu w latach 1820-1920. Rocz. Tor. [T.] 31: 2004 s. 101-135, sum., Zsfg.

138. NOWACKI Tadeusz W.: Zwycięska walka młodzieży o szkołę polską 1901-1917. Prz. Hist.-Ośw. R. 48: $2005 \mathrm{nr}$ 3/4 s. 51-87.

W zaborze pruskim i rosyjskim.

139. NOWAK Janusz: Od jaśnie panienek do córek zwykłych emigrantów - działalność oświatowa księżnych Hotelu Lambert. W: Czartoryscy - Polska - Europa. Historia i współczesność. Pod red. Zbigniewa Barana. Kraków 2003 s. 216-224.

140. OBORNY Aneta: Życie muzyczne w środowisku kieleckich gimnazjalistów w czasach Stefana Żeromskiego. W: Kielce i kielczanie w XIX i XX wieku. Pod red. Urszuli Oettingen. Kielce 2005 s. $45-64$.

141. PACHOLAK Marian: Pośród filomackich darów dla szkoły powiatowej w Kownie. Edycje wrocławskie. Acta Univ. Wr. No 2779: Prace Liter. [T.] 45: 2005 s. 45-89.

142. PAWELEC Ewa: Czasopisma dla dzieci i młodzieży lat siedemdziesiątych XIX wieku narzędziem edukacji patriotycznej. Studia Bibliol. $A S ́$. T.9: 2005 s. 95-109, sum.

143. POZNAŃSKI Karol: Obraz szkół prywatnych i elementarnych rządowych w Królestwie Polskim w raportach wizytatorów z 1853 r. Prz. Hist.-Ośw. R. 48: 2005 nr 3/4 s. 115-134.

144. RUSZKOWSKA Monika: Działalność prawników kieleckich na rzecz upowszechniania oświaty na przełomie XIX i XX wieku. W: Kielce i kielczanie w XIX i XX wieku. Pod red. Urszuli Oettingen. Kielce 2005 s. $65-85$.

145. SPOSOBY rozstrzygania sporów polityczno-osobistych na przykładzie zatargu profesorów Uniwersytetu Jagiellońskiego: Władysława Leopolda Jaworskiego i Stanisława Strońskiego z 1913 roku. Do dr. przygot. Przemysław Marcin Żukowski. Studia Hist. R. 48: 2005 z. 1 s. 99-110.

146. STINIA Maria: Podręczniki w gimnazjach galicyjskich w latach 1860-1918. Pr. Komis Hist. Nauki. T. 6: 2004 s. 5-39.

Uzup.: Dyskusja. Tamże s. 40-44. 
147. SZEWCZYK Izabela: Opieka nad dzieckiem przestępczym na ziemiach polskich w XIX wieku. Rocz. Nauk Spot. T. 33: 2005 z. 2 s. 85-102, sum.

148. SZOT Adam: Szkolnictwo polskie na Białostocczyźnie w latach 1915-1919 (w okresie okupacji niemieckiej). Nasza Przesztość. [T.] 104: 2005 s. 163-195, sum.

149. TYSZKIEWICZ Jan: Studenci lwowscy w Pieninach jesienią 1836 roku. Pr. Pienińskie. T. 15: 2005 s. $181-185$.

150. WALEWANDER Edward: Wychowawcza działalność Kościoła na ziemiach polskich w drugiej połowie XIX wieku w ramach stowarzyszeń rzemieślniczych i gospodarskich. Annales UMCS. Sec. F: Historia. Vol. 60: 2005 s. 391-399.

151. WALEWANDER E.: Wydawnictwa religijne w działalności wychowawczej Kościoła na ziemiach polskich w drugiej połowie XIX wieku. W: Ku Niepodległej. Ścieżki polskie i francuskie 1795-1918. Pod red. Małgorzaty Willaume. Lublin 2005 s. 267-279.

152. WESOŁOWSKA Sylwia: Szkolnictwo wiejskie na Pomorzu w XIX wieku. W: Dzieje wsi pomorskiej. II Międzynarodowa Konferencja Naukowa, Włościbórz, gmina Dygowo, powiat kołobrzeski, 23-24 maja 2003. Materiały. Pod red. Radosława Gazińskiego i Andrzeja Chludzińskiego. Dygowo-Szczecin 2003 s. 41-48.

153. WISZ Piotr: Saletyńska szkoła apostolska w Piźnikach (1906-1911). Resovia Sacra. R. 9/10: 2002/2003 [dr.:] 2004 s. 149-168, sum.

154. WOŁCZUKOWA Janina: Rosja i Rosjanie w szkołach Królestwa Polskiego 1833-1862. Szkice do obrazu. Wrocław 2005 Wydaw. Uniw. Wrocławskiego ss. 395, nlb. 1, tabl. 12, sum. (Acta Universitatis Wratislaviensis. No 2827).

155. WRÓBEL-LIPOWA Krystyna: Kształcenie dzieci w pałacu i dworze ziemiaństwa polskiego w XIX wieku. W: Ku Niepodległej. Ścieżki polskie i francuskie 1795-1918. Pod red. Małgorzaty Willaume. Lublin 2005 s. 147-162.

156. WYBÓR pism filomatów. Konspiracje studenckie w Wilnie 1817-1823. Oprac. Alina Witkowska. Wrocław-Warszawa 2005 Zakł. Nar. im. Ossolińskich - Wydaw.; we współpr. z De Agostini Polska ss. CLXVI, 423, nlb. 2. (Skarby Biblioteki Narodowej).

157. ZIĘBA Michał: Utwory romantyków polskich w procesie kształcenia galicyjskiej młodzieży szkolnej w latach 1860-1900 - Uwagi na marginesie badań nad recepcją. Annales APC. Folia 25: Studia ad Bibliothecarum. [T.] 3: 2005 s. 213-222, abstr.

158. ŻBIKOWSKA-MIGOŃ Anna: Wrocławski księgozbiór Johanna Ephraima Scheibla w kręgu zainteresowań Uniwersytetu Wileńskiego na początku XIX wieku. Rocz. Bibliot. R. 49: 2005 s. 383-396, Zsfg. 
159. BIEGAŃSKA Maria: Polityka ratunkowa i zdrowotna rządu Stanów Zjednoczonych i II Rzeczypospolitej: Państwowy Komitet Pomocy Dzieciom i Polsko-Amerykański Komitet Pomocy Dzieciom w Lodzi. Arch. Hist. i Filoz. Med. R. 68: 2005 s. 195-206, sum., Zsfg.

160. CIĄŻELA Andrzej: Filozofia kultury i wychowania Bogdana Suchodolskiego [1903-1992] w latach Drugiej Rzeczypospolitej. Warszawa 2005 Wyższa Szkoła Społ.-Ekonom. ss. 191. (Biblioteka Pedagogiki Pracy. T. 131).

161. DOBRJANS'KIJ Bogdan: Škl'nictvo u Drogobičí -míž dvoma svítovimi víjnami. W: Drohobycz - miasto wielu kultur. Pod red. Włodzimierza Bonusiaka. Rzeszów 2005 s. 105-115.

162. GONDEK Elżbieta: Oświata w regionie. W: Zagłębie Dąbrowskie w II Rzeczypospolitej (1918-1939). Praca zbior. pod red. Jana Walczaka. Sosnowiec 2005 s. 191-225.

163. GRADKOWSKI Henryk: Słowacki w nauczaniu szkolnym II Rzeczypospolitej. Acta Univ. Wr. No 2779: Prace Liter. [T.] 45: 2005 s. 245-263.

164. GWADERA Małgorzata: Polskie księgozbiory pedagogiczne w województwie śląskim w latach 1922-1939. Katowice 2005 Wydaw. Uniw. Śląskiego ss. 162, nlb. 2, sum., Zsfg.

165. HEINRICH Edward: Luźne kartki ze wspomnień uniwersyteckich. Spisane przez starego dorpatczyka. Wyd. 2, popr. Warszawa 2003 Stow. Filistrów Konwentu Polonia w Warszawie ss. 162.

Żył w 1. 1841-1922; Wyd. 1. Warszawa 1917.

166. HOROCH Emil: Działalność Bezpartyjnego Bloku Współpracy z Rządem w środowisku młodzieżowym i robotniczym w województwie lubelskim. Annales UMCS. Sec. F: Historia. Vol. 60: 2005 s. 323-334.

Lata 1930-1934.

167. JABŁONOWSKI Marek: Wychowanie fizyczne i przysposobienie wojskowe w opiniach Józefa Piłsudskiego 1926-1935 (wybrane zagadnienia). Echa Przeszlości. [T.] 6: 2005 s. 107-118, sum.

168. JAKUBIAK Krzysztof: Kształcenie pedagogów w II Rzeczypospolitej. Acta Elbingensia. T. 1: 2003 s. $33-49$.

169. JAKUBIAK Marek Aleksander: Bohaterowie walk o niepodległość Rzeczypospolitej w wybranych podręcznikach do historii $\mathrm{z}$ lat trzydziestych $\mathrm{XX}$ wieku. Niepodlegtość $i$ Pamięć. R. 12: $2005 \mathrm{nr} 1$ s. $155-166$.

170. JAROSZUK Teresa: „Stare i nowe” w poglądach Zenona Klemensiewicza na osobowość nauczyciela Polski Odrodzonej (1918-1939). Prz. Hist.-Ośw. R. 48: 2005 nr 1/2 s. 187-200.

171. JAROSZUK T.: Świat w szkole. Twórczość wspomnieniowa nauczycieli Polski Odrodzonej (1918-1939). Olsztyn 2005 Wydaw. Uniw. Warmińsko-Mazurskiego ss. 177, nlb. 1.

172. JASRZĘBOWSKA Elżbieta: Konstanty Régamey rodem z Renesansu w Uniwersytecie Warszawskim (1925-1939). Prz. Hist. T. 96: 2005 z. 1 s. 91-97.

Kompozytor i krytyk muzyczny, żyjący w 1. 1907-1982. 
173. JUŚKO Edmund: Działalność władz szkolnych oraz kierowników szkół w powiecie tarnowskim w zakresie szkolnictwa powszechnego w latach 1918-1939. Rocz. Hum. T. 53: 2005 z. 2 s. $117-136$, sum.

174. KALINOWSKA Anna: Od "szkoły śmierci” do "szkoły życia" - medycyna w reformie szkolnictwa doktora Korczaka. W: Między literaturą a medycyną. Literackie i pozaliterackie działania środowisk medycznych a problemy egzystencjalne człowieka XIX i XX wieku. Red. nauk. Eugenia Łoch, Grzegorz Wallner. Lublin 2005 s. 77-88.

175. KĘPKOWSKA Bożena: Działalność oświatowa Stowarzyszenia Mechaników Polskich z Ameryki w Pruszkowie w okresie międzywojennym. Prz. Hist.-Ośw. R. 48: 2005 nr 3/4 s. $135-150$.

176. KONOPKA Hanna: Między wychowaniem narodowym a wychowaniem państwowym w programach nauczania historii szkoły powszechnej (1918-1939). APC. Folia 29: Studia ad Institutionem et Educationem Pertinentia. [T.] 1: 2005 s. 115-123, abstr.

177. KUMOR Bożena: Działalność Śląskiej Szkoły Bibliotekarskiej (Schlesische Bibliotheksschule in Breslau) w latach 1932-1933. Przyczynek do dziejów bibliotekarstwa śląskiego okresu międzywojennego. Rocz. Bibliot. R. 49: 2005 s. 449-461, Zsfg.

178. LISIAK Henryk: Endecja i sanacja w walce o wpływy na uczelniach poznańskich. Pozn. Zesz. Hum. T. 5: 2005 s. 59-65, sum.

179. LUBIŃSKI Andrzej: Kronika ochronki polskiej w Mikołajkach Pomorskich w latach 1920-1939. W: Z dziejów Sztumu i okolic. Cz. 4. Sztum 2005 s. 135-148.

180. ŁACH Halina: Rola prasy jako źródła w badaniach działalności oświatowo-kulturalnej i wychowawczej w Korpusie Ochrony Pogranicza. W: Piechota i szkolnictwo piechoty Wojska Polskiego w pierwszej połowie XX wieku, stan i postulaty badań nad ich dziejami. W: Źródła w badaniach historii wojskowej. VII Ogólnopolskie Forum Historyków Wojskowości, Siedlce, 17-18 września 2003 r. Red. nauk. Kazimierz Pindel. Toruń 2004 s. 207-214. Inst. Historii Akad. Podlaskiej, Stow. Historyków Wojskowości.

181. LUKOMSKI Grzegorz: Szkoła wyznaniowa czy mieszana? Spór księdza kanonika Stanisława Adamskiego z Bernardem Chrzanowskim, kuratorem Okręgu Szkolnego Poznańskiego, o ideowy kształt wielkopolskiego szkolnictwa, lipiec-listopad 1922 roku. W: W kręgu chrześcijańskich tradycji starego kontynentu. Praca zbior. pod red. Marcelego Kosmana. Poznań 2005 s. $145-152$.

182. MALISZEWSKI Krzysztof: Teoria wychowania moralnego w pedagogice kultury II Rzeczypospolitej. Katowice 2004 Wydaw. Uniw. Śląskiego ss. 189.

Rec.: Śliwerski Bogusław, Rocz. Pedag. T. 28: 2005 s. 213-215.

183. MAŁOLEPSZY Eligiusz: Polityka władz II Rzeczypospolitej wobec wychowania fizycznego i sportu na wsi. Pr. Nauk. Akad. im. J. Dlugosza w Częstochowie. Kultura Fizyczna. [Z.] 6: 2005 s. $57-65$, abstr.

184. NOWARSKI Czesław: Historycy uniwersyteccy Lwowa wobec problemów edukacji historycznej (1918-1939). W: Lwów. Miasto - społeczeństwo - kultura. Studia z dziejów Lwowa. T. 5: Ludzie Lwowa. Pod red. Kazimierza Karolczaka. Kraków 2005 s. 386-396. 
185. OLCZAK-KARDAS Monika: Biblioteki uczniowskie szkół powszechnych w Polsce w latach 1918-1939. Studia Bibliol. AŚ. T.9: 2005 s. 181-94, sum.

W aneksie: Postanowienie Ministerstwa Wyznań Religijnych i Oświecenia Publicznego w sprawie regulaminu dla bibliotek uczniowskich w szkołach powszechnych z 11 VII 1939 r.

186. OLSTOWSKI Przemysław: Przedszkola i ochronki w międzywojennym Toruniu. Rocz. Tor. [T.] 31: 2004 s. 215-226.

187. PRZYGODZKI Jacek: Problem kształcenia kandydatów na wyższe stanowiska urzędników administracji w pracach Komisji dla Usprawnienia Admnistracji Publicznej z 1928 roku. Acta Univ. Wr. No 2758: Prawo. [T.] 294: Studia historycznoprawne: 2005 s. 235-249, Zsfg.

188. RATAJCZAK Grzegorz: Od Szkoły Żandarmerii do Centrum Wyszkolenia Żandarmerii w Grudziądzu. Rocz. Grudz. T. 16: 2005 s. 111-123.

Lata 1918-1939.

189. SAJA Piotr: Akcenty patriotyczne w wychowaniu i przygotowaniu obronnym społeczeństwa województwa pomorskiego w okresie międzywojennym. Rocz. Tor. [T.] 32: 2005 s. 51-76, sum., Zsfg.

190. SANOJCA Karol: Obraz sąsiadów w szkolnictwie powszechnym Drugiej Rzeczypospolitej. Wrocław 2003 Wydaw. Uniw. Wrocławskiego ss. 166.

Rec.: Białokur Marek, Prz. Hist.-Ośw. R. 48: 2005 nr 3/4 s. 281-285.

191. SIEDLACZEK-SZWED Aleksandra: Wybrane formy działalności wychowawczej Kościoła katolickiego w Polsce w latach 1918-1939. W: Z dziejów Polski XIX i XX wieku. Księga jubileuszowa ofiarowana profesorowi Ryszardowi Szwedowi. Red. nauk. Tadeusz Dubiecki, Tadeusz Panecki. Częstochowa 2004 s. 217-232.

192. SIKORSKI Marek: Myśl wychowawczo-szkoleniowa Marszałka Józefa Piłsudskiego w latach 1918-1935. Toruń 2005 Adam Marszałek ss. 182, il.

193. SKŁADANOWSKI Henryk: Idea wychowania wojskowego w publicznych szkołach powszechnych w Drugiej Rzeczypospolitej. W: Od armii komputowej do narodowej. [T.] 2: Dzieje militarne Polski i jej wschodnich sąsiadów od XVI do XX wieku. Pod red. Macieja Krotofila, Aleksandra Smolińskiego. Toruń 2005 s. 313-318.

194. SOBCZYK Jan Kazimierz: Katolicka młodzież wołomińska w latach 1928-1939. Rocz. Wotom. T. 1: 2005 s. 183-191.

Wspomnienia.

195. SPIS nauczycieli pracujących w powiecie kolbuszowskim w roku 1924. Odpis wykonała Halina Dudzińska. Rocz. Kolbusz. Nr 8: 2005 s. 293-297.

196. STRZEMIESKI Krzysztof: Obraz edukacji w sanacyjnej Polsce w świetle zapisków uczniowskich. Acta UNC. Nauki Hum.-Społ. Z. 365: Pedagogika. [Nr] 23: Historia Wychowania. 2004 s. 95-105.

197. SUDOL Adam: Tam był mój dom... Dzieciństwo w rodzinnej Lipnicy, gimnazjum w Rzeszowie 1931-1936. Sanok 2005 Drukarnia „Piast Kołodziej” ss. 261, tabl. 62.

Wspomnienia ur. w 1920 r. księdza, syna gospodarza z Lipnicy i posła na Sejm Ustawodawczy, ukazujące dzieciństwo na tle dziejów rodzinnej wsi i ówczesnej sytuacji gospodarczej, społecznej i politycznej oraz naukę w I Gimnazjum im. S. Konarskiego w Rzeszowie i jego dzieje od XVIII w. 
Kontynuacja w tomie: Moja droga do kapłaństwa. Małe Seminarium w Przemyślu 1936-1939, Seminarium Duchowne Przemyskie w Lesie Brzozowskim 1940-1945. Sanok 2005 ss. 364, blb. 1, tabl. 42, il.

198. SZCZEŚNIAK Jolanta: Czasopismo dziecięce doktora Janusza Korczaka. Pr. Nauk. UŚ w Katowicach. Nr 2298: Studia Bibliologicze. T. 15: 2005 s. 82-91, rez., sum.

„Mały Przegląd”, bezpłatny dodatek do „Naszego Przeglądu”, ukazujący się od 1926 r.

199. WALBURG Mirosława: Troska o dziecko na łamach lokalnej prasy miasta Kutna w dwudziestoleciu międzywojennym. Kutn. Zesz. Region. T. 9: 2005 s. 219-246.

200. WALISZEWSKI Stanisław: Gimnazjalne miraże. Dopełnienia. Rogoźno 2004 Tow. Przyj. Rogoźna ss. 75, il. (Biblioteka Rogozińskich Zeszytów Historycznych. Nr 2).

Stanowi kontynuację książki: Gimnazjalne miraże. Wspomnienia. Rogoźno 2001.

201. WLCZYŃSKI Leszek: Materiały źródłowe do historii duszpasterstwa akademickiego w Poznaniu w dwudziestoleciu międzywojennym. Na podstawie zbiorów Archiwum Archidiecezjalnego w Poznaniu. Studia Gnesnensia. T. 18: 2004 s. 303-318.

202. WYSOCKI Tomasz: Struktura narodowościowa wychowanków przedszkoli, według języka prowadzenia zajęć w II Rzeczypospolitej w roku 1937/38. Prz. Hist.-Ośw. R. 48: 2005 nr 1/2 s. $151-158$.

203. WYSOCKI T.: Struktura narodowościowa uczniów szkół powszechnych według języka w II Rzeczypospolitej w roku szkolnym 1937/38. Prz. Hist.-Ośw. R. 48: 2005 nr 3/4 s. $185-194$.

204. WYSOCKI T.: Umiejętność czytania i pisania w grupach wyznaniowych zamieszkujących Polskę w świetle wyników Spisu Powszechnego z 1931 roku. Rozpr. Dziej. Ośw. T. 44: 2005 s. $105-135$, sum.

205. WYSZCZELSKI Lech: Edukacja i przysposobienie obronne społeczeństwa w Polsce w latach 1921-1926. Prz. Hist.-Ośw. R. 48: 2005 nr 1/2 s. 31-49.

206. ZIELIŃSKI Konrad: Uwagi na temat opieki nad sierotami i dziećmi opuszczonymi w Polsce w okresie międzywojennym. Almanach Hist. T. 7: 2005 s. 149-169.

\section{Okres 1939-1945}

207. GÓRAL Jan: Szkolnictwo polskie w Piotrkowskiem w latach okupacji hitlerowskiej (1939-1944). Piotrk. Zesz. Hist. T. 5: 2003 s. 315-335, sum.

208. GROCHOWINA Sylwia: Niemieckie szkolnictwo powszechne na Pomorzu Gdańskim w latach 1939-1945. W: Społeczeństwo pomorskie w latach okupacji niemieckiej 1939-1945. Materiały XII sesji popularnonaukowej w Toruniu w dniu 15 listopada 2004 roku. Pod red. Katarzyny Minczykowskiej i Jana Szilinga. Toruń 2004 s. 83-101.

209. KALISZ Jan: Nauczycielstwo hrubieszowskie w okresie okupacji hitlerowskiej. Hrubieszów-Lublin 2004 Nakł. autora; Polihymnia ss. 136, il. (Biblioteka Towarzystwa Regionalnego Hrubieszowskiego. T. 38). 
210. MARKIEWICZ Leon: Losy pedagogów Śląskiego Konserwatorium Muzycznego w „czasach pogardy". W: Losy inteligencji śląskiej w latach 1939-1945. T. 2. Pod red. Zbigniewa Kapały. Bytom 2005 s. 140-150.

211. MIKITIUK Renata: Polityka hitlerowska wobec szkolnictwa polskiego w Generalnym Gubernatorstwie z uwzględnieniem dystryktu lubelskiego. Krak. Studia Malopol. Nr 7: 2003 s. $301-324$, sum.

212. MIKULSKI Zdzisław: Okupacyjna szkoła zawodowa profesorów Wydziału Inżynierii Politechniki Warszawskiej. (Przyczynek do dziejów okupacyjnego szkolnictwa zawodowego). Rozpr. Dziej. Ośw. T. 44: 2005 s. 203-209, sum.

213. PIERZCHAŁA Henryk: Pomocne dłonie Europejczyków (1939-1944). Kraków 2005 Wydaw. i Poligrafia Pijarów ss. 653, il.

Międzynarodowa pomoc dla polskich naukowców uwięzionych w obozach Dachau i Sachsenhausen-Oranienburg.

214. TAJNE studia medyczne w Warszawie 1940-1944. Pod red. Andrzeja Zaorskiego. Warszawa 2004 Tow. Lekarskie Warszawskie ss. 285, il.

Antologia wspomnień.

Rec.: Ostrowska Teresa, Arch. Hist. i Filoz. Med. T. 67: 2004 z. 1 s. 108-110; Ostrowska T., Kw. Hist. Nauki i Techn. R. 49: 2004 nr 3/4 s. 250-252.

215. TORZEWSKI Bernard: 60 lat minęło. Nieznane fakty z dziejów budynku przy ul. Seminaryjnej. Kron. Bydg. T. 26: 2004 [dr.:] 2005 s. 421-425.

Lehrbildungsakademie (Akademia Kształcenia Nauczycieli) w Bydgoszczy w 1. 1943-1945.

216. TRELA-MAZUR Elżbieta: Sowiecki system oświatowy na ziemiach wschodniej Polski na przykładzie Wydziału Oświaty Ludowej we Lwowie (1939-1940). W: Okupacja sowiecka ziem polskich 1939-1941. Pod red. Piotra Chmielowca. Rzeszów-Warszawa 2005 s. 83-93.

217. WINCENCIAK Witold: Łomżyńskie tradycje oświatowe a szkolnictwo w czasach radzieckiej i niemieckiej okupacji (1939-1945). Łomża 2001 Łomżyńskie Tow. Nauk. im. Wagów ss. 227 , il., rez., sum.

218. WRÓBEL-LIPOWA Krystyna: Dzieci polskie w Związku Radzieckim w czasie II wojny światowej. Wsch. Rocz. Hum. T. 2: 2005 s. 369-383, sum., rez.

219. WRZOSEK Mieczysław: $Z$ dziejów tajnego nauczania i wojskowej konspiracji na południowo-zachodnich obszarach Południowego Podlasia w latach 1939-1944. Studia Podl. T. 15: 2005 s. $71-106$, abstr., rez.

220. ZANIEWSKA Teresa: Szkolnictwo polskie w Szwajcarii w czasie II wojny światowej. Pr. Komis. Hist. Nauki. T. 6: 2004 s. 95-117.

Uzup.: Dyskusja. Tamże s. 117-122.

221. ZIMIŃSKA Magda: Postawy młodzieży i nauczycieli obwodu białostockiego pod radzieckim zaborem (1939-1941). Studia Podl. T. 15: 2005 s. 35-70, abstr., rez. 


\section{Okres $1945-1989$}

222. ADAMCZAK Tomasz: Działalność Oddziału Powiatowego Towarzystwa Burs i Stypendiów Rzeczypospolitẹ Polskiej w Mińsku Mazowieckim. Rocz. Mińsko-Maz. Z. 13: 2005 s. 64-67.

W 1. 1946-1951.

223. AUSZ Mariusz: Obraz COP w polskich podręcznikach historii okresu PRL-u. W: Centralny Okręg Przemysłowy. Infrastruktura - produkcja - procesy miastotwórcze. Materiały konferencji naukowej odbytej w Radomiu 19 grudnia 2005 roku. Pod red. Sebastiana Piątkowskiego. Radom 2005 s. $123-130$.

224. BOBIK Bogumiła: Odbudowa i rozwój szkolnictwa w Gliwicach, Bytomiu i Zabrzu w latach 1945-1950. Rocz. Muz. Gliw. T. 19: 2004 [dr.:] 2005 s. 179-213, sum., Zsfg.

225. CHAŃKO Jan, Onufrzak Zbigniew: $Z$ dziejów konspiracji młodzieżowych w Lodzi 1948-1953. Łódź 2005 PTH ss. nlb. 4, 363, il. Oddz. Łódzki PTH.

226. CHŁOPEK Maciej: Bikiniarze. Pierwsza polska subkultura. Warszawa 2005 Żak ss. 168, il.

Recc.: Brzostek Błażej, Dzieje Najnowsze. R. 37: 2005 nr 3 s. 235-239.

227. CHMIELEWSKI Witold: Nielegalne organizacje młodzieżowe w liceach pedagogicznych w latach 1945-1956. Prz. Hist.-Ośw. R. 48: $2005 \mathrm{nr}$ 1/2 s. 97-107.

228. CHMIELEWSKI W.: Problemy w polityce oświatowej w pierwszych latach po drugiej wojnie światowej. Prz. Hist.-Ośw. R. 48: 2005 nr 3/4 s. 97-114.

229. CHMIELEWSKI W.: Z zagadnień polityki oświatowej w latach 1944-1946. W: Region, kraj, świat. Studia ofiarowane Profesorowi Stanisławowi Tadeuszowi Olejnikowi w siedemdziesiątą rocznicę urodzin. Pod red. Janusza R. Budzińskiego. Piotrków Trybunalski 2005 s. 301-323.

230. CHOMA-JUSIŃSKA Małgorzata: Rola duszpasterstwa akademickiego o. Ludwika Wiśniewskiego w działalności opozycji przedsolidarnościowej w Lublinie. Pamięć i Sprawiedliwość. 2005 [nr] 1 s. 155-179, sum.

231. FUDALI Robert: Przemiany roli społecznej nauczycieli na Dolnym Śląsku w latach 1945-1975. Zielona Góra 2004 Oficyna Wydawnicza Uniw. Zielonogórskiego ss. 218, nlb. 1, il. Uniw. Zielonogórski.

232. GĄSOWSKI Tomasz: Inwigilacja krakowskich uczelni przez Służbę Bezpieczeństwa w latach 1980-1985. Sowiniec. Nr 27: 2005 s. 51-61.

233. GIZOWSKI Mariusz: Społeczne uwarunkowania rozwoju szkolnictwa i oświaty mniejszości narodowych i grup etnicznych w strukturach PRL (na przykładzie mniejszości ukraińskiej). Gdań. Zap. Hist.-Spot. T. 1: 2004 [dr.:] 2005 s. 60-63.

234. GRYZ Ryszard: Sprawozdanie z operacyjnego rozpracowania młodzieży i nauczycieli przez Wojewódzki Urząd Bezpieczeństwa Publicznego w Kielcach (luty 1954 r.). Almanach Hist. T. 7: 2005 s. 233-247.

W aneksie tekst sprawozdania.

235. JAKUBOWSKA Barbara: Przodujący uczniowie, studenci i robotnicy - zlot młodzieży w Krakowie, lipiec 1973 roku. Annales APC. Folia 29: Studia ad Institutionem et Educationem Pertinentia. [T.] 1: 2005 s. 45-53, abstr. 
236. KIETLIŃSKI Marek: Niezależny ruch młodzieżowy na Białostocczyźnie w latach 1980-1989. Białystok 2005 Książnica Podlaska im. Lukasza Górnickiego; Pryzmat ss. 120, il.

237. KIJOWSKI Maciej: Przewodniczący Rady Państwa jako Przewodniczący Rady Głównej Przyjaciół Harcerstwa (1968, 1972-1985). Zesz. Nauk. Uniw. Rzesz. Nr 34: Ser. Prawnicza: Prawo. [Z.] 3: 2005 s. 136-158.

238. KONOPKA Hanna: Nauczanie religii w województwie łódzkim na tle innych regionów. W: Władze komunistyczne wobec Kościoła katolickiego w Łódzkiem 1945-1967. Pod red. Janusza Wróbla i Leszka Próchniaka. Warszawa 2005 s. 135-144.

239. KOWALCZUK Zygmunt: Nadzór państwowy nad Wyższymi Seminariami Duchownymi w Polsce w latach 1960-1961 na przykładzie Wyższego Seminarium Duchownego w Gorzowie Wielkopolskim. Studia Zach. Nr 6: 2002 s. 243-250, Zsfg.

240. KOZERAWSKI Dariusz [Stanisław]: Archiwalia do dziejów wojskowego szkolnictwa akademickiego w latach 1947-1967. W: Piechota i szkolnictwo piechoty Wojska Polskiego w pierwszej połowie XX wieku, stan i postulaty badań nad ich dziejami. W: Źródła w badaniach historii wojskowej. VII Ogólnopolskie Forum Historyków Wojskowości, Siedlce, 17-18 września 2003 r. Red. nauk. Kazimierz Pindel. Toruń 2004 s. 184-191.

241. KOZERAWSKI D. S.: Kształcenie kandydatów na oficerów zawodowych piechoty i wojsk zmechanizowanych we Wrocławiu w latach 1947-1962. Śl. Kw. Hist. Sobótka. R. 60: 2005 nr 2 s. 185-206, Zsfg.

242. KOZERAWSKI D. S.: Wyższe szkolnictwo wojskowe w Polsce w latach 1947-1967. Warszawa 2005 Neriton ss. 409, il., sum.

243. KRAWCZYK Magdalena: Stan szkolnictwa w województwie rzeszowskim w latach 1944-1948. Pr. Hist.-Archiw. T. 16: 2005 s. 113-131.

244. KRÓL Joanna: Uchronić przed zapomnieniem - średnie szkoły ogólnokształcące w województwie szczecińskim w latach 1945-1948. Szczecin 2005 Wydaw. Nauk. Uniw. Szczecińskiego ss. 185, nlb. 2, il., sum. Uniw. Szczeciński. (Rozprawy i Studia. T. (631) 557).

245. KSIĄŻNICKA Krystyna: Działalność Powiatowej Poradni Kulturalno-Oświatowej na rzecz środowiska wiejskiego. Formy i metody pracy. Miel. Zap. [T.] 5/6: 2002/2003 [dr.:] 2003 s. $163-178$.

Lata 1966-1975.

246. KUBALKA Jacek: Szkolnictwo specjalne w Polsce w polityce oświatowej państwa w latach 1944-1948. Prz. Hist.-Ośw. R. 48: 2005 nr 3/4 s. 151-168.

247. KUSIAK Franciszek: Żołnierze Śląskiego Okręgu Wojskowego wobec wydarzeń studenckich w marcu 1968 r. w świetle meldunków. Śl. Kw. Hist. Sobótka. R. 60: 2005 nr 1 s. 79-96.

248. KUŹMA Ewa: Likwidacja analfabetyzmu w powiecie tomaszowskim $w$ latach 1945-1953. Krak. Studia Malopol. Nr 9: 2005 s. 227-240, sum.

Tomaszów Lubelski.

249. KUŹMA E.: Przebieg i organizacja „Tygodnia Oświaty, Książki i Prasy” na Zamojszczyźnie w latach 1949-1952. Krak. Studia Matopol. Nr 7: 2003 s. 325-334, sum. 
250. LESIAKOWSKI Krzysztof: Powstanie Powszechnej Organizacji „Służba Polsce” w 1948 r. Z polityki stalinowskiej wobec młodzieży polskiej. Prz. Nauk Hist. R. 1: 2002 nr 1 s. 123-143, sum.

251. LUBISZEWSKA Bogumiła: Toruńskie duszpasterstwo ojców jezuitów ze szczególnym uwzględnieniem duszpasterstwa akademickiego (1945-1970). Rocz. Tor. [T.] 32: 2005 s. 133-160, sum., Zsfg.

252. MACHALEK Małgorzata: Nauczyciele szczecińscy w stanie wojennym. W: Stan wojenny w skali kraju i Pomorza Zachodniego. Informacje źródłowe i refleksje. Materiały z sesji naukowej zorganizowanej przez Szczecińskie Towarzystwo Naukowe, Instytut Politologii Uniwersytetu Szczecińskiego, Archiwum Państwowe w Szczecinie i Instytut Pamięci Narodowej Oddział w Poznaniu, 26 listopada 2004 roku. Praca zbiorowa. Pod red. M. Machałek i Jana Macholaka. Szczecin 2005 s. $233-240$.

253. MAUERSBERG Stanisław, Walczak Marian: Szkolnictwo polskie po drugiej wojnie światowej (1944-1956). Warszawa-Radom 2005 PTP ZG; Wydaw. Inst. Technologii Eksploatacji ss. 275, sum. Pol. Tow. Pedagog. Zarząd Gł.

Rec.: Kryńska Elwira, Prz. Hist.-Ośw. R. 48: 2005 nr 3/4 s. 275-278; Sadowska Joanna, Studia Podl. T. 15: 2005 s. 374-377.

254. MEZGLEWSKI Artur: Ograniczanie przez władze państwowe działalności szkolnictwa wyznaniowego w latach 1948-1964 jako przejaw instrumentalizacji prawa na poziomach jego stanowienia i stosowania. W: Prawo i polityka wyznaniowa w Polsce Ludowej. Materiały z II Ogólnopolskiego Sympozjum Prawa Wyznaniowego (Kazimierz Dolny, 26-28 października 2004). Pod red. Artura Mezglewskiego, Piotra Stanisza, Marty Ordon. Lublin 2005 s. 235-262.

255. MICHALSKI Andrzej: Ewolucja planów i programów nauczania szkół muzycznych I i II stopnia oraz ognisk muzycznych w XX-leciu PRL. Toruń 2005 Tow. Nauk. Organizacji i Kierownictwa „Dom Organizatora” ss. 61, sum.

256. MIELCAREK Damian: Echa wydarzeń marca 1968 roku na Opolszczyźnie w świetle materiałów archiwalnych i prasowych. Pr. Uczes. Stud. Dokt. [T.] 5: Historia: 2003 s. 105-118.

257. MIELCAREK D.: „Niepokoje uniwersyteckie” w 1968 roku, czyli wystąpienia studentów w państwach zachodnich w świetle doniesień polskiej prasy. Pr. Uczes. Stud. Dokt. [T.] 7: Historia: 2004 s. $141-154$.

258. MIKITIUK Renata: Organizacja szkolnictwa powszechnego na terenie Okręgu Szkolnego Lubelskiego w okresie Rządu Tymczasowego. Krak. Studia Małopol. Nr 8: 2004 s. 323-341, sum.

Rok 1945.

259. MIKITIUK R.: Struktura i liczebność szkół powszechnych na terenie okręgu szkolnego lubelskiego w latach 1944-1947. Krak. Studia Małopol. Nr 9: 2005 s. 207-225.

260. OKRASA Marzena: Funkcjonowanie internatów i burs w latach 1944-1949 w województwie lubelskim. Prz. Hist.-Ośw. R. 48: $2005 \mathrm{nr}$ 3/4 s. 195-215.

261. ORDON Marta: Proces likwidacji Stowarzyszeń „Opieka nad Dziewczętami” (1946-1962). Prawo-Administracja-Kościót. $2001 \mathrm{nr} 2 / 3$ s. 243-269, Zsfg. 
262. OŚWIATA, wychowanie i kultura fizyczna w rzeczywistości społeczno-politycznej Polski Ludowej (1945-1989). Rozprawy i szkice. Pod red. Romualda Grzybowskiego. Torun 2004 Adam Marszałek ss. 428, sum.

Treść: Grzybowski R.: Wstęp s. 9-14; Cz. 1. Polityczne i ideologiczne uwarunkowania rozwoju oświaty polskiej po roku 1945: Meissner Andrzej: Ewolucja poglądów na dzieje oświaty w Polsce w latach 1944-1956 s. 17-26; Gawlik Stanisław: Budowa podstaw nowego ladu szkolnego (1944-1948) s. 27-42; Grzybowski R.: Przełomy polityczne jako momenty zwrotne w polityce oświatowej PRL s. 43-57; Michalska Iwonna: Między polityką a nauką. Ostatnie lata działalności Naukowego Towarzystwa Pedagogicznego. [Lata 1945-1958] s. 59-68; Król Joanna: Polityka rekrutacyjna w odniesieniu do szkól licealnych a generowanie nowej inteligencji polskiej (na przykładzie województwa szczecińskiego w latach 1945-1990) s. 71-82; Pawelec Lidia: Raport o stanie oświaty w PRL - 1973 rok s. 83-91; Wojdon Joanna: Partyjna kontrola nad podręcznikami szkolnymi w Polsce Ludowej s. 93-103; Cz. 2. Nauczyciel w strukturach systemu oswiatowego Polski Ludowej: Chodakowska Janina: Dorobek II Rzeczypospolitej w usprawnieniu kształcenia w uniwersytetach s. 107-114; Mauersberg Stanisław: Indoktrynacja komunistyczna nauczycieli polskich w latach 1947-1956 s. 115-123; Mielczarek Ferdynand: Ideał pedeutologiczny w Polsce w latach 1945-1956 s. 125-137; Szkoda Edward: Kwalifikacje nauczycieli w okresie Polski Ludowej (na podstawie wybranych regulacji resortu oświaty) s. 139-149; Jałmużna Tadeusz: $Z$ tradycji kształcenia nauczycieli na ziemi łódzkiej (na przykładzie Zgierza). [Lata 1919-1991] s. 151-155; Kowalska-Matelska Joanna: Związek Nauczycielstwa Polskiego w latach 1945-1980. Stan badań i perspektywy badawcze s. $157-166 ; \mathrm{Cz}$. 3. Oświata i wychowanie w perspektywie ogolnopolskiej: Kryńska Elwira J.: Organizacje młodzieży szkół średnich w latach 1948-1956 s. 169-181; Maliszewski Tomasz: Polskie uniwersytety ludowe w latach 1945-1948. Szkic do dziejów polskiej oświaty dorosłych lat 40 . XX wieku s. 183-191; Majewski Stanisław: Przemiany organizacyjno-programowe szkolnictwa średniego ogólnokształcącego w Polsce w latach 1944-1961 s. 193-209; Jakubiak Krzysztof: Problematyka wychowania rodzinnego $\mathrm{i}$ relacji rodziny ze szkołą w polskim piśmiennictwie pedagogicznym w latach 1945-1956 s. 211-219; Michalski Andrzej: Stan źródeł do dziejów wychowania artystycznego w Polsce po 1945 roku s. 221-237; Magiera Elżbieta: Wychowanie morskie na łamach „Płomyczka” i „Płomyka” w Polsce Ludowej s. 239-247; Cz. 4. Szkolnictwo i oświata polska w perspektywie regionalnej i lokalnej: Sapia-Drewniak Eleonora: Wpływ polityki społecznej na edukację ludności rodzimej na Śląsku Opolskim po II wojnie światowej s. 251-260; Walasek Stefania: Szkolnictwo i oświata na Dolnym Śląsku po II wojnie światowej (zarys problematyki) s. 261-268; Gorloff Elżbieta: Tworzenie się sieci szkół średnich i zawodowych w Lęborku w latach 1945-1975 s. 269-279; Malik Magdalena: Oświata dorosłych na Dolnym Śląsku - stan źródel (1945-1955) s. 281-289; Rędziński Kazimierz: Opieka nad dziećmi żydowskimi w Częstochowie w latach 1939-1947 s. 291-303; Kolakowski Andrzej: Okoliczności powstania i pierwsze lata działalności domów dziecka w województwie gdańskim po roku 1945 s. 305-315; Apanel Danuta: Instytucjonalna opieka całkowita nad dzieckiem na Pomorzu Środkowym w latach 1945-1975 s. 317-328; Jankowski Robert: Organizacja szkolnictwa morskiego na Pomorzu Zachodnim po II wojnie światowej s. 329-334; Cz. 5. Uczeni w systemie polityczno-oświatowym Polski Ludowej: Sztobryn Sławomir: Ludwik Bandura i Kazimierz Sośnicki jako historycy myśli pedagogicznej. Analiza międzywojennej twórczości czasopiśmienniczej s. 337-346; Michalski Grzegorz: Udzial Zygmunta Myslakowskiego w reorientacji ideowo-programowej ZNP w pierwszych latach po II wojnie światowej s. 347-358; Żerko Józef: Profesor Kazimierz Kubik [1910-1986] pionier i organizator środowiska naukowego historyków oświaty i wychowania w Gdańsku s. 359-369; Cz. 6. Kultura fizyczna w Polsce po roku 1945. Kontekst polityczny: Chełmecki Jerzy: Sytuacja i ogólne prawidłowości rozwoju kultury fizycznej w okresie PRL. Historia wychowania fizycznego w latach PRL s. 373-381; Ponczek Mirosław: Elementy kultury fizycznej w działalności duszpasterskiej kościoła rzymskokatolickiego lat Polski Ludowej (do 1988 roku) s. 383-387; Moska Waldemar: Próby restrukturyzowania sfery kultury fizycznej w Polsce w latach osiemdziesiątych XX wieku s. 389-392; Sokołowski Maciej: Studia nauczycielskie jedną z form ksztalcenia nauczycieli wychowania fizycznego w PRL (na przykładzie SN-u w Zgierzu) s. 393-403.

Toż. [Wyd. 2]. Torún 2005 ss. 428, il., sum.

263. PAJĄCZKOWSKI Stanisław: Nauczycielskie spółdzielnie księgarsko-papiernicze na Dolnym Śląsku w latach 1945-1949. Szkice Leg. T. 26: 2005 s. 251-260.

264. PAWLAK Marian: Kilka uwag o zamknięciu prywatnych szkół katolickich we Włocławku w latach 1948-1951. Ateneum Kapt. T. 144: 2005 z. 1 s. 106-115, argum., sum., Zsfg. 
265. PIÓREK Marian: Struktura szkolnictwa podstawowego i kadra nauczycielska w powiecie kolbuszowskim w latach 1973-1975 (szkoły i ich filie, nauczyciele, wykształcenie, specjalność i studia). Rocz. Kolbusz. Nr 6: 2002 [dr.:] 2003 s. 185-199.

266. POGORZAEA Ewa: Problem upaństwowienia szkół Centralnego Komitetu Żydów w Polsce w latach 1945-1949. Prz. Hist.-Ośw. R. 48: $2005 \mathrm{nr} 1 / 2$ s. 51-68.

267. PULIŃSKA Urszula: Doskonalenie zawodowe nauczycieli szkół ogólnokształcących na Warmii i Mazurach w latach 1945-1989. Olsztyn 2005 Wydaw. Uniw. Warmińsko-Mazurskiego ss. 209 , il.

268. RZEMIENIUK Florentyna: Oświata w województwie siedleckim w okresie stanu wojennego (1981-1989). Siedlce 2005 Florentyna Rzemieniuk ss. 369, nlb. 3, il.

269. STĘPIEŃ Roman: Szkolnictwo niemieckie w Legnicy po II wojnie światowej. Kalendarz ważniejszych wydarzeń. Szkice Leg. T. 26: 2005 s. 239-250.

270. SULEJA Teresa, Suleja Włodzimierz: Wydarzenia marcowe we Wrocławiu w świetle materiałów OOP Wydziału Prawa Uniwersytetu Wrocławskiego. W: Studia politologiczne i historyczne. Księga jubileuszowa dedykowana profesorowi Bronisławowi Pasierbowi. Red. nauk. Czesław Osękowski, Jarosław Macała. Zielona Góra 2005 s. 455-463.

271. SZCZUCHNIAK Przemysław: Rozwój oświaty i repolonizacji w powiecie sztumskim po 1945 r. W: Z dziejów Sztumu i okolic. Cz. 4. Sztum 2003 s. 161-172.

Narodowo-Polityczny Ośrodek Wychowawczy w Sztumie.

272. SZYMCZAK Małgorzata: Królowe, bohaterki, święte - portrety kobiet średniowiecza i renesansu na kartach powojennych podręczników do historii. W: Europa Środkowo-Wschodnia. Ideologia, historia a społeczeństwo. Księga poświęcona pamięci profesora Wojciecha Peltza. Red. nauk. Jarosław Dudek, Daria Janiszewska, Urszula Świderska-Włodarczyk. Zielona Góra 2005 s. 47-52. Uniw. Zielonogórski.

273. ŚLĘCZKA Ryszard: Nauczycielstwo krakowskie wobec zmian w oświacie (1944-1948). Annales APC. Folia 29: Studia ad Institutionem et Educationem Pertinentia. [T.] 1: 2005 s. 36-44, abstr.

274. TESARSKA Aneta: Szkolny obraz wieszcza. Wizerunek Juliusza Słowackiego kreowany w podręcznikach dla średnich szkół ogólnokształcących po 1945 roku. Acta Univ. Wr. No 2659: Prace Liter. [T.] 44: 2004 s. 267-281.

275. THAU (Weczer) Maria: Powroty. Kraków 2002 Wydaw. i Drukarnia Tow. Słowaków w Polsce ss. 158, nlb. 2, il.

Wspomnienia Żydówki z pobytu w Domu Dziecka w Warszawie w 1. 1945-1956.

276. TRACZ Renata: Rozwój szkolnictwa w Trzebiatowie po 1945 roku. W: Trzebiatów - spotkania pomorskie 2004 r. Pod red. Janiny Kochanowskiej. Wołczkowo 2005 s. 80-87.

277. TRZEBIATOWSKI Włodzimierz: Rola lwowskich przedstawicieli nauk chemicznych w środowisku wrocławskim. Oprac. Aleksandra Lewanowicz. Wrocław 2005 Oficyna Wydawnicza Politech. Wrocławskiej ss. 84, nlb. 2, tabl. 18, il.

Po $1945 \mathrm{r}$. 
278. WALLIS Janina: Szkolnictwo zawodowe na Ziemi Lubuskiej w latach 1945-1956. W: Z dziejów Ziemi Lubuskiej po drugiej wojnie światowej. T. 1. Red. nauk. Czesław Osękowski. Zielona Góra 2005 s. 139-181.

279. WARCHAŁOWSKI Krzysztof: Usunięcie nauczania religii ze szkół publicznych w latach 1958-1961. W: Prawo i polityka wyznaniowa w Polsce Ludowej. Materiały z II Ogólnopolskiego Sympozjum Prawa Wyznaniowego (Kazimierz Dolny, 26-28 października 2004). Pod red. Artura Mezglewskiego, Piotra Stanisza, Marty Ordon. Lublin 2005 s. 325-332.

280. WIŚNIEWSKA Krystyna: Z dziejów oświaty w parafii Klon po drugiej wojnie światowej. Rocz. Mazur. T. 9: 2005 s. 115-121.

W 1. 1945-1964.

281. WITEK Danuta: Szkolnictwo podstawowe Lubelszczyzny w latach 1944-1961. Radzyń Podlaski 2005 Danuta Witek; Radzyński Ośr. Kultury i Rekreacji ss. 266.

282. WOJNA z bigbitem. Oprac. Jacek Z. Sawicki. Zesz. Hist. Z. 152: 2005 s. 198-204.

Dokumenty z 1. 1961-1971, obrazujące stosunek władz PRL do kultury młodzieżowej.

283. ŻUKOWSKA Anna Marta: Studia nauczycielskie jako forma kształcenia nauczycieli rysunku i wychowania plastycznego w Polsce po II wojnie światowej. Prz. Hist.-Ośw. R. 48: 2005 nr $1 / 2$ s. $109-140$.

\section{Okres 1990-2005}

284. BUKOWSKA Edyta: [Juliusz] Słowacki w „Podstawie programowej” i programach nauczania okresu reformy oświaty (1990-2004). Acta Univ. Wr. No 2779: Prace Liter. [T.] 45: 2005 s. $265-289$.

285. DLUGOSZ Piotr: Młodzież Podkarpacia w III Rzeczypospolitej. Kraków 2005 Nomos ss. 264.

286. KULTURA w systemie wychowawczym Ochotniczych Hufców Pracy. Pod red. nauk. Zenona Jasińskiego, Edwarda Nycza; wstęp Z. Jasiński. Opole 2004 Antykwa ss. 304, il. Komenda G1. Ochotniczych Hufców Pracy w Warszawie, Opolska Woj. Komenda Ochotniczych Hufców Pracy, Inst. Nauk Pedagog. Uniw. Opolskiego.

Po 1989 r.; Materiały konferencji naukowej.

287. LENART Zbigniew: Pięć lat Ośrodka Akademickiego w Weryni-Kolbuszowej (2000-2005). Rocz. Kolbusz. Nr 8: 2005 s. 298-310.

288. POPIELIŃSKI Pawel: Instytucje wspierające działalność młodzieży mniejszości niemieckiej w Polsce i jej organizacji. Rocz. Pol.-Niem. [T.] 12: 2004 [dr.:] 2005 s. 117-138.

Po 1989 r.

\section{Oświata polonijna}

289. GODDEERIS Idesbald: Oświata polonijna w Belgii w pierwszych latach powojennych. Dzieje Najnowsze. R. 37: 2005 nr 1 s. 79-92, sum. 
290. GRĘDZIK Agnieszka: Oświata i szkolnictwo polskie na Białorusi 1989-2001. Cz. 1. Kielce 2004 PUHP „Graf-Us” ss. 183, il.

291. LANGE Roderyk: Etnografia i etnologia na Polskim Uniwersytecie na Obczyźnie (PUNO) w Londynie. Lud. T. 89: 2005 s. 225-235, sum.

292. MISZCZUK Marian: Harcerska prasa dla dzieci i młodzieży wydawana w Wielkiej Brytanii w latach 1941-1948. Warszawa 2004 Tomiko ss. 63. (Dzieje Harcerskich Wydawnictw Polonijnych i Emigracyjnych. T. 3).

293. MŁODE pokolenie polskich emigrantów - jego losy i problemy w XX wieku. Zbiór studiów. Pod red. Ryszarda Sudzińskiego. Włocławek 2004 Wyższa Szkoła Hum.-Ekonom.; Lega Oficyna Wydawnicza Włocławskiego Tow. Nauk. ss. 180, nlb. 4, sum.

Z treści: Danel Jacek Krzysztof: Działalność harcerska Kazimierza Sabbata w latach 1939-1967 s. 15-28; Sindecka Natalia: Harcerstwo polskie w Estonii okresu międzywojennego s. 29-36; Baran Adam F.: Organizacja i stan polskiego harcerstwa na Białorusi w latach 1997-2002 (zarys problematyki) s. 37-61; Later Chodyłowa Elżbieta: Zarys dziejów wychowania patriotycznego wśród Polonii w krajach skandynawskich s. 85-94; Stopikowska Małgorzata: Udział dzieci i młodzieży w organizacjach polskich i polonijnych na Wschodzie s. 95-113; Girzyński Zbigniew: Walka o „rząd dusz" w młodym pokoleniu polskich emigrantów we Francji na przykładzie Związku Młodzieży Polskiej „Grunwald” (1944-1950) s. 125-137; Golon Mirosław: Młodzież polska na studiach cywilnych i wojskowych w ZSRR w latach 1944-1950 s. 139-177.

294. SZKOŁY polskie we Lwowie (1944-2004). [Wyd.] Bożena Rafalska. Rocz. Lwow. 2005 s. $219-230$.

Wspomnienia absolwentów.

295. VALENTIN-STĄCZEK Ewa: Willardczycy. Życiorysy. Powstanie i funkcjonowanie polskiego liceum w Villard de Lans 1940-1946. Wyd. 2 popr. i uzup. Wrocław 2005 Ewa Valentin-Stączek ss. 511, il., mapy.

Gimnazjum i Liceum im. Cypriana Norwida w Villard-de-Lans we Francji w 1. 1939-1945.

Wyd. 1. 2003.

296. WALASZEK Adam: Naród, bohaterowie i wrogowie w podręcznikach szkolnych Polonii amerykańskiej (do 1. 30. XX w.). W: Kobiety i młodzież w migracjach. Pod red. Jana E. Zamojskiego. Warszawa 2005 s. 421-442. IH PAN, Mazowiecka Wyższa Szkoła Hum.-Pedag. w Łowiczu. (Migracje i Społeczeństwo. [T.] 10).

297. WĘGIER-MAKSYMOWICZ Krystyna: Szkoła księdza Kordeckiego we Lwowie i jej losy w latach 1940-1962 (szkoła nr 18 i szkoła nr 30). Niepodleglość i Pamięć. R. 12: 2005 nr 1 s. $215-251$.

\section{DZIEJE SZKóŁ RÓŻNYCH STOPNI}

\section{Szkoły podstawowe i zakłady wychowawcze}

298. BOROWIEC Teresa, Kawa Regina: Szkoła w Budziwoju w latach 1847-1973. Tyczyn-Rzeszów $2005 \mathrm{Gm}$. Tyczyn ss. 206, il.

299. DZIEJE oświęcimskiego szkolnictwa podstawowego. Pod red. Barbary Rokowskiej. Wadowice 2005 Drukarnia i Wydaw. Grafikon ss. 240, il. 
Z treści: Sordyl Brygida: Początki szkolnictwa podstawowego w Oświęcimiu s. 9-27; Ptaszkowski Jan: Z dziejów tajnego nauczania w Oświęcimiu s. 29-36; Ficek Dorota, Korycińska Małgorzata: Szkoła Podstawowa nr 1 s. 37-50; Strycharska Katarzyna: Szkoła Podstawowa nr 2 s. 51-73; Faruga Barbara: Szkoła Podstawowa nr 3 w Oświęcimiu s. 75-90; Baran Elżbieta, Zajas Iwona, Maciborek Jolanta, Filipowicz Jolanta: Szkoła Podstawowa nr 4 s. 91-98; Tobiasz Jan, Brak-Parcer Bożena, Zimirska Danuta: Szkoła Podstawowa nr 5 s. 99-128; Wisła Helena, Paradowska-Kwiatkowska Magdalena: Szkoła Podstawowa nr 6 w Dworach s. 129-138; Zarząd Osiedla „Manowice”: Szkoła Podstawowa nr 7 w Manowicach s. 139-148; Węglarz Anna, Grzybek Mariola: Szkoła Podstawowa nr 7 s. 149-156; Majer Elżbieta: Szkoła Podstawowa nr 8 s. 157-173; Malarczuk Katarzyna, Górkiewicz Andrzej: Szkola Podstawowa nr 9 s. 175-189; Tyrański Stanisław: Szkoła Podstawowa nr 10. Specjalny Ośrodek Szkolno-Wychowawczy s. 191-198; Kozieł Anna, Wieczorek Marta: Szkoła Podstawowa nr 11 s. 199-214; Kozieł Agnieszka: Państwowa Szkoła Muzyczna s. 215-224.

300. DZIEJE samorządowej szkoły podstawowej w Międzylesiu - księga pamiątkowa. [Aut.] Antonina Leśniak-Osadkowska [i in.]. Międzylesie 2005 Samorządowa Szkoła Podstawowa ss. 244 , il.

301. ECHA tczowskiej ziemi. Pod red. Krystyny Kołodziejczyk, Jana Madeja, Macieja Stawarza. Sycyna-Warszawa 2005 Stow. Oświatowe Sycyna; Wyższa Szkoła Pedagog. ZNP ss. 272, tabl. 16, il. (Biblioteka Sycyńska. Monograficzna ser. wydawnicza. T. 19).

Z treści: Szkoły i przedszkola: Nędzi Alina: Szkoła w Bartodziejach s. 114-120; Kupis Elżbieta Ewa: Szkoła w Brzezinkach Starych s. 121-144; Wlazło Maria: Historia szkoły w Janowie s. 145-148; Piechota Zofia, Majewska Jolanta: Szkoła w Rawicy s. 149-153; Kołodziejczyk K.: Dzieje szkoły w Tczowie s. 154-167; Wierzbicka Zofia, Zientecka Teresa Anna, Pietrzyk Elżbieta Teresa: Historia szkoły w Wilczym Ługu s. 168-177.

302. GĄTARCZYK Agnieszka: Sesja naukowa z okazji 75-lecia szkoły im. ks. Seweryna Czetwertyńskiego w Suchowoli. Suchowola, [25 X] 2003. Wsch. Rocz. Hum. T. 1: 2004 s. 477-480.

303. HISTORIA ludźmi pisana. 50 lat szkolnictwa specjalnego w Tczewie. Zespół red. Teresa Petka [i in.]. Pelplin-Tczew 2003 „Bernardinum”; Specjalny Ośr. Szkolno-Wychowawczy ss. 267, nlb. 5, il.

Z treści: Rys historyczny s. 9-47; Specjalny Ośrodek Szkolno-Wychowawczy s. 48-89; Od „klas życia” po zespoły edukacyjno-terapeutyczne s. 90-94; Internat SOSW w Tczewie s. 95-98; Z życia Szkoły Zawodowejkronika wydarzeń s. 99-105; Wspomnienia s. 106-140; Zakończenie s. 141-144; Indeks pracowników s. $145-165$.

304. HOLEKSA Gabriela: Zespół Szkół nr 8 w Żorach. Monografia wydana z okazji 25-lecia Szkoły Podstawowej nr 16 im. Marii Konopnickiej w Żorach. Żory 2005 Zespół Szkół nr 8 ss. 70. nlb. 2, tabl. 8.

305. JUBILEUSZ 50-lecia Szkoły Podstawowej nr 6 w Cieszynie-Pastwiskach. Kom. red. Eugenia Jędrusiak [i in.]. Cieszyn 2005 Offsetdruk i Media ss. 124, il.

306. KISELYCZKA Jolanta: 50 lat szkoły w Złockiem. Almanach Muszyny. [R.] 15: 2005 s. $217-222$.

Lata 1953-2003.

307. KUSTUSZ Gaudenty: Wejherowska szkoła publiczna prowadzona przez OO. Reformatów (1650-1824). Rocz. Gdań. T. 65: 2005 z. 1/2 s. 85-120, sum.

308. MATUSZEWSKI Adam: Historia szkoły leszczyńskiej (w świetle dotychczasowych opracowań i źródeł). Przyj. Ludu. [R. 19]: 2004 [dr.:] 2005 z. 1 s. 20-25.

Od XVI w. 
309. MONOGRAFIA Szkoły Podstawowej nr 2 w Kępnie 1945-2004. Oprac. zespół red. Lidia Luźniak [i in.]. Kępno-Kalisz 2004 Agencja Wydawnicza Sztuka i Rynek ss. 117, nlb. 4, il.

310. NIWIŃSKI Tomasz: Uczniowie Specjalnego Ośrodka Szkolno-Wychowawczego w Żywcu w latach 1968-1998. Annales APC. Folia 29: Studia ad Institutionem et Educationem Pertinentia. [T.] 1: 2005 s. $184-189$.

311. [OSIEMDZIESIĄT] 80 lat włoszczowskiej „Jedynki”. Pod red. Jacka Kosińskiego. Włoszczowa 2005 Szkoła Podst. nr 1 im. J. Piłsudskiego ss. 270, il.

Zespół Placówek Oświatowych nr 1 we Włoszczowej.

Treść: Kościński J.: Kartki z dziejów Włoszczowy s. 9-14; Maciejczyk Emilia: Oświata we Włoszczowie w XIX i na początku XX wieku s. 15-21; Falana Izabela: Charakterystyka ekonomiczna i socjologiczna Włoszczowy s. 22-30; Kościński J.: Historia szkoły s. 31-64; Jasiowska Bożena: Patron szkoły s. 65-70; Machnik Ewa: Józef Piłsudski 1867-1935 s. 71-89; Kościński J., Orlińska Ewelina: Dyrektorzy szkoły - biogramy s. 90-102; Falana I., Orlińska E., Kościński J.: Wspomnienia o szkole s. 103-125; Kuzincow Katarzyna, Maciejczyk Emilia: Najstarsza organizacja w szkole - ZHP s. 126-133; Kościński J.: Konkursy i olimpiady s. 134-138; Krawczyk Dariusz: Osiągnięcia sportowe s. 139-148; Jasiowska B.: Szkoła z klasą to my s. 149-152; Kościński J.: Z życia szkoły s. 153-156; Kościński J., Maciejczyk Emilia: Trochę statystyki s. 157-182; Kaczmarek Jadwiga, Kościński J.: Szkoła w obiektywie s. 183-193; Orlińska E.: Wykaz absolwentów 1929-2003 s. 194-263; Orlińska E.: Uczniowie i kadra w roku jubileuszowym s. 264-270.

Toż. Wyd. 2, popr. i uzup. Włoszczowa 2005.

312. PRZYŁĘK - nasza ziemia. Pod red. Mariana Kusia. Sycyna 2005 Wydaw. Stow. Oświatowego Sycyna ss. 255, tabl. 16, il. (Biblioteka Sycyńska. Monograficzna ser. wydawnicza. T. 20).

Z treści: Oświata: Marszałek Danuta: Szkoła w Babinie s. 101-115; Czemiak Jadwiga: Szkoła w Grabowie nad Wisłą s. 115-126; Stankiewicz Andrzej: Szkoła w Lucimi s. 127-130; Pawlukowska Teresa: Szkoła w Laguszowie s. 130-137; Cieślik Marzena: Szkoła w Ławeczku Starym s. 138-141; Grzybowska Ewa: Szkoła w Mszadli Starej s. 142-150; Kamionka Jerzy: Szkoła w Przyłęku s. 151-161; Dudek Danuta: Szkoła Podstawowa w Rudkach s. 161-162; Pastuszko Sławomir: Szkoła w Wólce Zamojskiej s. 162-168.

313. SPADKOBIERCY i powstańcy. Szkoła Podstawowa nr 30 im. Powstańców 1863 r. w Warszawie (1934-2004). Pod red. Alicji Mierzejewskiej-Wągiel. Łomianki-Warszawa 2004 Heliodor; staraniem Szkoły Podst. nr 30 im. Powstańców 1863 roku ss. 140, il.

314. SZCZERBATKO Kazimierz: Szkoła zakroczymska. Zakroczym 2005 Urząd Gm. ss. 215, il. XX-XXI w.

315. SZEŚCIEDZIĄT lat minęło... Kalendarium wydarzeń z dziejów Szkoły Podstawowej nr 1 im. Orła Białego w Świdwinie w latach 1945-2004. Red. Anna Strońska. Toruń 2005 Adam Maszałek ss. 73 , il.

316. [SZEŚĆDZIESIĄT] 60 lat Szkoły Podstawowej nr 15 im. Bronisława Czecha w Jeleniej Górze. Oprac. merytoryczne Zbigniew Stępień [i in.]. Jelenia Góra 2005 Alex Drukarnia Wydaw. Tomasz Mączka ss. 123, nlb. 9, il.

317. SZKOLNICTWO na Górnym Śląsku XIX i XX wieku. 200 lat szkoły w Potępie 1803-2003. Materiały z konferencji naukowej. Krupski Młyn 2005 Urząd Gm. ss. 40, tabl. 6.

$Z$ treści: Szczech Bernard: Potępa w świetle wybranych źródeł drukowanych z lat 1783-1865 s. 6-14; Dola Kazimierz: Szkolnictwo w rejencji opolskiej w XIX wieku s. 15-20; Kuzio-Podrucki Arkadiusz, Woźnicki Dariusz: Właściele Potępy i Tworoga. Ich dzieje i heraldyka, wkład w rozwój społeczno-ekonomiczny s. 21-29; Kuzio-Podrucki A.: Dzieje szkoły w Potępie w latach 1803-72 (wg ks. Henryka Gawelczyka) oraz 1907-1945 (wg Kroniki Szkoły) s. 30-40. 
318. SZKOŁA w Pawłowie. Tradycje i współczesność. Zespół red. Wiktor Cieśla [i in.]. Pawłów-Starachowice 2005 Zespół Szkół; U.P.Z.P. „Dorand” T.S. Cisek ss. 89, il.

Wyd. specjalne z okazji nadania szkole imienia Jana Pawła II, 15 X 2005 r.

XIX-XXI w.

319. WOJKOWSKA Anna: Historia wychowania przedszkolnego na terenie miasta i gminy Wołomin Rocz. Wołom. T. 1: 2005 s. 143-172.

Od 1919 r.

320. ZAWADA Bartosz: Żydowski Dom Dziecka w Otwocku 1945-1948. Kw. Hist. Żydów. [R. 5]: 2005 nr 1 s. 69-82, sum.

321. ZESPÓ£ Szkół Sportowych nr 2 w Chorzowie. Oprac. Danuta Gurgul, Jolanta Teper. Chorzów [2005 B.w.] ss. 46.

W 1. 1964-1994.

322. ZIÓŁEK Ewa M.: Z dziejów szkoły w Opolu Lubelskim. Res Historica. T. 20: 2005 s. $223-227$.

XVIII-XIX w.

\section{Szkoły ponadpodstawowe ogólnokształcące}

323. BACAŃSKA Halina, Krotkiewicz Jerzy, Szlązak Wiesław: W świat przez naszą szkołę. Monografia Liceum im. Unii Horodelskiej w Horodle (1944-2004). Lublin 2005 Polihymnia ss. 186, nlb. 2, il. (Biblioteka Towarzystwa Regionalnego Hrubieszowskiego. Nr 39).

324. BASIŃSKA Maria: 60 lat Liceum Ogólnokształcącego w Strzelnie. Technikum, Liceum Ekonomiczne w Strzelnie 1963-1974. Współpr. Kazimierz Chudziński [i in.]. Strzelno 2005 Liceum Ogólnokształcące; Tow. Miłośn. M. Strzelna ss. 167, nlb. 1.

325. BRZEZIŃSKI Kazimierz: 90 lat szkolnej tradycji 1915-2005. Pod red. K. Brzozowskiego; słowo wstępne Elżbieta Szpakowska. Pabianice 2005 Stow. Absolwentów II LO im. Królowej Jadwigi; Pabianickie Zakł. Graficzne ss. 334, il. II Liceum Ogólnokształcące im. Królowej Jadwigi w Pabianicach.

326. CHOWANIEC-LEJCZYK Bronisław: Gimnazjum w Podolińcu - szkoła synów Podhala. W: Góry i góralszczyzna w dziejach i kulturze pogranicza polsko-słowackiego (Podhale, Spisz, Orawa, Gorce, Pieniny). [Cz. 1]: Historia. Materiały z międzynarodowej konferencji naukowej Kraków-Nowy Targ-Bukowina Tatrzańska, 21-24 października 2004. Praca zbior. pod red. Jerzego M. Roszkowskiego i Roberta Kowalskiego. Nowy Targ 2005 s. 17-26. Podhalańska Państ. Wyższa Szkoła Zawodowa w Nowym Targu.

327. DĘBIŃSKI Józef: Biskupie Gimnazjum im. ks. Jana Długosza we Włocławku w latach 1916-1939. Studia Wtoc. T. 8: 2005 s. 355-369.

328. [DRUGIE] II Liceum Ogólnokształcące im. Marii Konopnickiej w Nowym Sączu. Stulecie Szkoły. Post scriptum. Pod red. Marii Kruczek. Nowy Sącz 2004 PTH. Oddz.; Zespół Szkół Ogólnokształcących im. Marii Konopnickiej ss. 115, il.

Treść: Kruczek M.: Prywatne Seminarium Nauczycielskie Żeńskie im. Marii Konopnickiej w Nowym Sączu 1903-1936 s. 17-45; Kruczek M.: Prywatne Gimnazjum Żeńskie i Liceum Ogólnokształcące im. Marii Konopnickiej w Nowym Sączu 1932-1939 s. 47-66; Kruczek M.: Szkoła w latach okupacji niemieckiej 
1939-1945 s. 67-73; Kruczek M.: Prywatne Gimnazjum Żeńskie i Liceum Ogólnokształcące im. Marii Konopnickiej w Nowym Sączu w latach 1945-1948 s. 75-90; Kruczek M.: Państwowa Szkoła Ogólnokształcąca Stopnia Podstawowego i Licealnego im. Marii Konopnickiej w Nowym Sączu 1948-1959 s. 91-126; II Liceum Ogólnokształcące im. Marii Konopnickiej w Nowym Sączu 1959-2003: Kruczek Władysław: Struktura organizacyjna i baza materialna s. 129-139; Gruca Irena: Biblioteka szkolna s. 140-151; Mţck-Kardel Maria: Działalność dydaktyczno-wychowawcza s. 152-182; Kutowska Anna, Ogorzałek Jacek: Kadra pedagogiczna, pracownicy administracji i obsługi s. 183-223; Bolanowski Leszek: Formy aktywności pozalekcyjnej s. 224-253; Golonka Aleksandra, Kardaszyńska Małgorzata: Opieka nad młodzieżą s. 254-263; BogdańskaSkuza Krystyna, Drożdżak Maria, Martelus-Szafer Beata: Absolwenci s. 264-295; Kruczek W.: Uczniowie i absolwenci - zestawienie za lata 1960-2003 s. 296-298; Kruczek M.: Sylwetki dyrektorów s. 299-338; Kruczek M.: Aneks s. 341-487.

329. [DZIESIĘCIOLECIE] X-lecie Liceum Ogólnokształcącego i Zasadniczej Szkoły Zawodowej w Krzywniu 1993-2003. Monografia. Pod red. Małgorzaty Durek i Renaty Kołak. Krzywiń 2003 Zespół Szkół Ponadgimnazjalnych ss. 54, nlb. 2, tabl. 16, il.

330. FIRST Grzegorz: Gabinet archeologiczny w I Gimnazjum w Nowym Sączu i jego twórca Stanisław Rzepiński [1861-1944]. Almanach Sqdec. R. 14: 2005 nr 1/2 s. 11-23.

Gabinet utworzony w r. 1899.

331. GAJEWSKA Barbara, Wiktorska Elżbieta: I Liceum im. Tadeusza Kościuszki w Koninie i jego rola w edukacji młodzieży regionu konińskiego. Rocz. Konin. T. 15: 2005 s. 213-233.

Od 1863 r.

332. GAJOWIEC Bogumiła: W cieniu mieleckiego Gimnazjum 1938-1951. Miel. Zap. [T.] 5/6: 2002/2003 [dr.:] 2003 s. 130-148.

333. GIERMKOWSKI Marian: Szkoła dziewięćdziesięciu lat. II Liceum Ogólnokształcące im. Hetmana Jana Zamoyskiego w Lublinie. Lublin 2005 Petit; na zlec. II Liceum Ogólnokształcącego im. Hetmana Jana Zamoyskiego ss. 96, il.

XX-XXI w.

334. GLIŃSKI Jan Bohdan: Gimnazjum i Liceum im. Sułkowskich w Rydzynie 1928-1939. Wychowawcy i wychowankowie. Warszawa 2005 Fund. im. Tadeusza Łopuszańskiego ss. 423, il.

335. GOLNIK-SZCZEGÓLSKA Urszula, Szczygielska Magdalena, Kozyra Bogumiła: 100 lat na Smolnej czyli Dzieje Gimnazjum i Liceum im. Jana Zamoyskiego w Warszawie. Współpr. Anna Grocholska, Emilia Kędziorek. Warszawa 2005 XVIII Liceum Ogólnokształcące im. J. Zamoyskiego ss. 183 , il.

336. IWANIUK Aleksander, Sakowski Bazyli: Liceum Białoruskie w Hajnówce. Białystok-Hajnówka 2000 Białoruskie Zrzeszenie Studentów; Liceum Ogólnokształcące ss. 126.

Po 1944 r.

337. KOLAK Wacław: Krótkie istnienie prywatnego gimnazjum i liceum OO. Augustianów w Prokocimiu w latach 1945-1947. Krak. Rocz. Archiw. [T.] 11: 2005 s. 222-228.

Dzielnica Krakowa.

338. KONTOWT-OKULEWICZOWA Irena, Kalenkiewicz-Mirowiczowa Anna Krystyna: Państwowe Gimnazjum im. św. Kazimierza w Nowej Wilejce. Wspomnienia. Red. Leszek Jan Malinowski. Bydgoszcz 2003 Tow. Miłośn. Wilna i Ziemi Wileńskiej ss. 184, il., mapa. (Biblioteka Wileńskich Rozmaitości. Seria B nr 48). 
339. KOZLOWSKA Elżbieta Maria: „Sześćdziesiąt lat minęło...”. I Liceum Ogólnokształcące im. Wacława Nałkowskiego w Wołominie. Ząbki 2004 Apostolicum Wydaw. Księży Pallotynów Prowincji Chrystusa Króla ss. 222, nlb. 1, il.

Po 1945 r.

Rec.: Stryjek Jarosław, Rocz. Wotom. T. 1: 2005 s. 289-292.

340. KRYSIAK Marian Piotr: Średnie szkoły ogólnokształcące w Kolnie (1918-2000). Olecko 2001 Wydaw. Wszechnicy Mazurskiej ss. 262, il. (Acta Universitatis Masuriensis) (Episteme. [T.] 14).

341. KSIĘGA pamiątkowa. 125 lat Gimnazjum Męskiego im. Królowej Zofii - I Liceum Ogólnokształcącego im. Komisji Edukacji Narodowej w Sanoku. Pod red. Małgorzaty Szybiak. Sanok 2005 Stow. Absolwentów i Sympatyków I Liceum Ogólnokształcącego im. Komisji Edukacji Narodowej ss. nlb. 2, 346, nlb. 3, il.

XIX-XXI w.

342. KSIĘGA pamiątkowa czarniecczyków. VIII Zjazd Czarniecczyków, Chełm 2005. T. 4-5. Zespół red. Adam Cichowicz [i in.]. Chełm 2005 Drukarnia „Kresowa” Adam Bednaruk; na zlec. Stow. Czarniecczyków i Przyj. I Liceum Ogólnokształcącego ss. 354, nlb. 1, il.; 430, il.

I LO im. Stefana Czarnieckiego w Chełmie.

343. KSIĘGA pamiątkowa I Liceum Ogólnokształcącego w Lesznie. Praca zbiorowa. Pod red. Zdzisława Adamczaka i Aleksandra Piwonia. Leszno 2005 Urząd M. Leszna ss. 352, il.

XVII-XXI w.

344. KUCHTA-ZAWADZKA Aleksandra: Gimnazjum i liceum jezuitów w Gdyni. Rocz. Gdyń. Nr 17: 2005 s. 126-133.

$\mathrm{XX}$ w.

345. LENART Jolanta: Liceum Ogólnokształcące im. Janka Bytnara w Kolbuszowej na przełomie XX i XXI wieku (1999-2003). Rocz. Kolbusz. Nr 8: 2005 s. 231-292.

346. LICEUM Ogólnokształcące im. Powstańców Śląskich w Dobrzeniu Wielkim 1953-2003. Księga jubileuszowa. Pod red. Ryszarda Kałuży. Dobrzeń Wielki-Opole 2005 Wydaw. Inst. Śląski ss. 240, il. Zespół Szkół w Dobrzeniu Wielkim.

Z treści: Mohylek Rudolf: Powstanie i rozwój szkoły s. 12-45; Krupa Jolanta: Kalendarium szkoły s. 46-48; Krupa J.: Dyrektorzy s. 63-66; Kutyma Manfred, Kałuża Ryszard: Funkcje dobrzeńskiego Liceum w środowisku s. 83-101; Kupczyk Jerzy: Życie kulturalne szkoły na przestrzeni lat s. 102-107; Wspomnienia s. 141-197.

347. LAKOMY Tadeusz: Długa i bogata tradycja... Miel. Zap. [T.] 5/6: 2002/2003 [dr.:] 2003 s. $149-153$.

Gimnazjum w Przecławiu w 1. 1944-1948.

348. MYDLACH Piotr: Stulecie II Liceum Ogólnokształcącego im. Tadeusza Kościuszki w Kaliszu. Rocz. Kalis. T. 31: 2005 s. 307-313.

Lata 1906-2005.

349. NALASKOWSKI Aleksander: Muzeum Przedmiotów Szkolnych jako integralna część Szkoły Laboratorium. Acta UNC. Nauki Hum.-Społ. Z. 365: Pedagogika. [Nr] 23: Historia Wychowania. 2004 s. 5-8.

Szkoła Laboratorium - Gimnazjum i Liceum Ogólnokształcące w Toruniu. 
350. NASIŃSKA Maria: Szkoła i jej Patron - o Liceum im. J. Słowackiego. Almanach Częstochowy. [T. 18]: 2004/2005 [dr.:] 2005 s. 200-207.

W Częstochowie, XX w.

351. OCALIĆ od zapomnienia... Zarys historii Liceum Ogólnokształcącego im. Krystyny Idzikowskiej w Zdunach. Kom. red. Marzena Tomaszewska, Ziemomysł Skibiński. Zduny-Lowicz 2005 Społ. Kom. Obchodów 60-lecia Liceum Ogólnokształcącego ss. 215, tabl. 40.

Z treści: Od Autorów s. 5-7; Tajne nauczanie w gminie Zduny w latach 1940-45 s. 17-33; Powstanie gimnazjum w Zdunach s. 35-42; Organizacja nauczania w latach 1945-2005 s. 43-64; Krystyna Idzikowska patronką szkoły s. 65-80; Kalendarium najważniejszych wydarzeń (1945-2005) s. 81-84; Z życia Liceum Ogólnokształcącego im. Krystyny Idzikowskiej w Zdunach - wspomnienia Absolwentów s. 115-179; Spis Absolwentów s. 181-215.

352. PUBLICZNE Liceum Ogólnokształcące $\mathrm{nr} 1 \mathrm{im}$. Mikołaja Kopernika w Opolu 1945-2005. Księga jubileuszowa z okazji 60-lecia szkoły i IV zjazdu absolwentów. Oprac. Jolanta Jakubowska [i in.]. Opole 2005 Wydaw. Inst. Śląski ss. 268, nlb. 3, il.

353. PUDŁOWSKI Tomasz: Stan i potrzeby badań nad dziejami I Liceum Ogólnokształcącego im. Juliusza Słowackiego w Przemyślu. Rocz. Przem. R. 40: 2004 z. 4 s. 65-84.

354. RECHAL-BYTNAR Zdzisława Józefa: Moja rodzinna ulica - kolbuszowskie Nowe Miasto w początkach obecnego stulecia. Pierwsze lata Prywatnego Gimnazjum w Kolbuszowej (1911-1916). Rocz. Kolbusz. Nr 5: 2001 s. 183-207.

355. SOWIŃSKI Henryk: Gimnazjum i Liceum im. Króla Władysława IV w Warszawie na Pradze. Monografia szkoły. T. 2: Gimnazjum i Liceum im. Króla Władysława IV w Warszawie na Pradze 1915-1944. Warszawa 2005 Koło Wychowanków Liceum im. Króla Władysława IV ss. 422 , nlb. 2, tabl. 124.

356. [STO] 100 lat „Kościuszki”. Pod red. Anety Kolańczyk; współpr. Elżbieta Piszczorowicz-Mondra, Jarosław Wujkowski. Kalisz 2005 Edytor ss. 460, il.

Szkoła Handlowa, Gimnazjum i Liceum im. Tadeusza Kościuszki w Kaliszu 1905-2005. Wydano z okazji VII Zjazdu Wychowanków Gimnazjum i Liceum im. T. Kościuszki oraz Liceum S. Sempołowskiej.

Z treści: Szkoła Handlowa, Gimnazjum i Liceum im. Tadeusza Kościuszki w Kaliszu. Zarys historyczny: Mydlach Piotr: Pierwsze dziesięciolecia (1905-1945) s. 13-60; Miklas Agata: Lata 1945-1980 s. 61-68; Hołysiak Irena: Lata 1980-1994 s. 69-74; Woźniak Maria: Lata 1994-1999 s. 75-82; Krzyżanowska-Koszycka Teresa, Rudowicz Małgorzata: IV Liceum Ogólnokształcące im. S. Sempołowskiej. „Wspomnienia serdeczne” s. 83-106; Stowarzyszenie Wychowanków Liceum Ogólnokształcącego im. T. Kościuszki w Kaliszu s. 107-121; Majchrzak Beata: Poczet dyrektorów Szkoły Handlowej, Gimnazjum i Liceum im. T. Kościuszki s. 127-149; Wspomnienia o nauczycielach s. 151-189; Wybitni absolwenci s. 191-226; Dyśko Wojciech, Margules Józef: Zawsze wierni. Sylwetki żołnierzy - absolwentów s. 227-278; Dyśko W.: Lista Katyńska absolwentów s. 279-288; Majchrzak B., Majchrzak Wacław: Zwycięzcy olimpiad i konkursów przedmiotowych s. 289-321; Skrzypczyńska Karolina, Wujkowski J.: Klub Europejczyka „Polonus” w latach 1993-2004 s. 323-328; Wujkowski J.: II Liceum Ogólnokształcące im. T. Kościuszki w latach 1999-2005 s. 331-377; Załączniki s. $381-457$.

357. STULECIE szkoły „pod Benedyktem” w Krakowie. Red. Halina Longa; życiorys patronki szkoły i historię szkoły oprac. Daria Grodzka. Kraków 2004 Poligrafia Inspektoratu Tow. Salezjańskiego ss. 92, il.

Gimnazjum nr 35 im. Zofii Chrzanowskiej w Krakowie, XX w.

358. SZCZEPANIAK Zdzisław: Kolegium jezuickie i konwikt w Kłodzku 1597-1945. Kłodzko-Nowa Ruda 2005 Maria ss. 209, il. 
359. SZCZEPANIAK Z.: Liceum ogólnokształcące im. Bolesława Chrobrego w Kłodzku 1945-2005. Kłodzko-Nowa Ruda 2005 Wydaw. Maria ss. 334, nlb. 5, il.

360. [SZEŚĆDZIESIĄT] 60 lat Liceum Ogólnokształcącego w Sulejówku 1944-2004. Szkoła, nauczyciele, wychowankowie. Praca zbior. pod red. A. Kołodziejczyka; przy współpr. Jana Barczyka, Jakuba Dziedzica, Tomasza Opalskiego. Sulejówek 2004 Liceum Ogólnokształcącego im. Ignacego Jana Paderewskiego ss. 304, tabl. 8, il.

Rec.: Bednarzak-Libera Mirosława, Prz. Hist.-Ośw. R. 48: 2005 nr 3/4 s. 293-297.

361. SZOT Adam: Zlikwidowanie Niższego Seminarium Duchownego w Różanymstoku 1954 r. Studia Teol. [T.] 23: 2005 s. 291-302, Zsfg.

362. ŚWISTAK Zdzisław: Dyrektorzy, profesorowie i wychowankowie Gimnazjum i Liceum im. Króla Stanisława Leszczyńskiego w Jaśle. Jasło-Tuchów 2001 Zdzisław Świstak; Mała Poligrafia Redemptorystów ss. 441, il.

$\mathrm{XIX}-\mathrm{XX}$ w.

363. TORZEWSKI Marian: Historia Gimnazjum i Liceum im. Henryka Sienkiewicza we Wrześni w latach 1919-2004. Wyd. nowe, zm. Września 2004 Prodruk ss. 351, il.

364. URBAŃCZYK Andrzej: Czarna księga moich niezdanych matur. Liceum im. Stefana Żeromskiego w Lęborku 1953, 1953, 1954. San Francisco-Gdańsk [i in.] 2004 Nord ss. 29.

Wspomnienia o maturalnych porażkach pisarza, podróżnika, żeglarza.

365. W DWUSETNĄ rocznicę założenia Gimnazjum Wołyńskiego. Rocz. Tow. Liter. im. A. Mickiewicza. R. 40: 2005 s. 33-190.

Treśc: Czaplejewicz Eugeniusz: Euzebiusz Słowacki na autostradzie czasu. (Szkic do portretu teoretyka i translatora) s. 33-53; Guzek Andrzej Krzysztof: Alojzy Feliński - między Warszawą a Krzemieńcem s. 55-68; Lyszczyna Jacek: Maurycy Gosławski - piewca Podola s. 69-77; Informacja o Tymonie Zaborowskim s. 78; Feliksiak Elżbieta: Stepowe tropy i szyfry w „Marii” Antoniego Malczewskiego s. 79-85; Makowski Stanisław: Krzemienieckie źródła twórczości Juliusza Słowackiego s. 87-97; Bachórz Józef: Krzemienieckie wzruszenia Józefa Korzeniowskiego s. 99-112; Fabianowski Andrzej: Franciszek Kowalski - pamiętmikarz Krzemieńca s. 113-124; Jakubowska-Krawczyk Katarzyna: Tomasz Padurra - romantyczny poeta i bard s. 125-140; Krysowski Olaf: Stefan Witwicki s. 141-153; Krzemińska Anna: Krzemieniec Tomasza Augusta Olizarowskiego s. 155-168; Wichrowska Elżbieta Z.: Karol Kazimierz Sienkiewicz (1793-1860) s. 169-190.

\section{Szkoły zawodowe}

366. JEST takie miejsce w Nowej Hucie... Jubileusz 50-lecia Zespołu Państwowych Szkół Muzycznych im. Mieczysława Karłowicza. Pod red. Jana Poprawy. Kraków 2004 Wydaw. MCDN; Zespół Państ. Szkół Muzycznych im. M. Karłowicza ss. 200. (Salon Jana Poprawy. Sezon 10. T. 33).

Z treści: Krótkie kalendarium szkoły s. 19-35; Rościszewska Krystyna: Wierna muzyce i orientalistyce (spisał Ryszard Dzieszyński) s. 36-39; Sitko Irena: Pierwszymi uczniami byli robotnicy kombinatu (spisała Diana Olejniczak) s. 40-44; Tryczyński Zdzisław: Prawie całe dorosłe życie s. 45-48; Feczko Elżbieta: Zaczęłam tutaj uczyć z przypadku (spisała D. Olejniczak) s. 49-52; Rajchel Dorota: Ocalić od zapomnienia s. 56-61; Doniec-Krzemień Roma: Wspomnienie s. 62-64; Marchewczyk Rafał: Nadzwyczajna historia nadzwyczajnego chóru s. 87-92; Dekasińska Urszula: Międzynarodowy Festiwal Klarnetowy s. 106-109; Poprawa J.: Promyki Krakowa s. 119-121; Pałczyńska Bogusława: Bez kompleksów s. 122-125; Malinowski Witold: Afera jazzowa w szkole muzycznej s. 128-131; Dyrektorzy szkoły 1954-2004 s. 161; Absolwenci szkoły 1963-2004 s. 162-195. 
367. [PIĘĆDZLIESIĄT] 50 lat Zespołu Szkół Rolniczych w Czartajewie, 1955-2005. Red. prow. Szczepan Kowalczuk. Czartajew 2005 Zespół Szkół Rolniczych ss. 162, nlb. 3, il.

Z treści: Kużel Andrzej, Kowalczuk S.: Rys historyczny. Od powstania szkoły do czasów współczesnych s. 7-13; Niewiadomska Nina, Borzym-Siemieniuk Anna: Internat s. 14-20; Dmitruk Maria, Homanowska Walentyna: Gospodarstwo Pomocnicze s. 21-29; Szyszko Rafał: Historia sportu w Czartajewie s. 30-44; Korzeniewska Dorota: Zespół Pieśni i Tańca „Złote Kłosy” s. 45-54; Stypułowa Zofia: Spotkania z ludźmi kultury i życia publicznego (1970-1990) s. 55-60; Wykazy i zestawienia s. 97-163.

368. PILUCH Małgorzata: Stuletnia historia Szkół Zawodowych im. Władysława Orkana w Starym Sączu. Stary Sącz 2003 ss. 55, il.

Wcześniej Seminarium Nauczycielskie Męskie.

Rec.: Duda Tadeusz, Rocz. Sqqdec. R. 33: 2005 s. 338-339.

369. [SZEŚĆDZIESIĄT] 60 lat szkoły rolniczej w Dzikowie - Tarnobrzegu. (Od Liceum Gospodarczego Wiejskiego w Dzikowie do Zespołu Szkół Ponadgimnazjalnych nr $2 \mathrm{im}$. Bartosza Głowackiego w Tarnobrzegu. Sandomierz-Dzików-Tarnobrzeg 2005 Prywatna Agencja Informacji Regionalnej Myjakpress; na zlec. Kom. Organizacyjnego 60-lecia Szkoły Rolniczej ss. 120, il. (Dzikoviana. [T.] 2).

370. [SZEŚĆDZIESIĄT] 60 lat Zespołu Szkół im. prof. Oskara Langego w Szczecinie. Red. nacz. Grażyna Dąbrowska. Szczecin 2005 Zespół Szkół Nr 3; Druk. Algraf ss. 239, il.

Od 1945 r.

371. URBANOWICZ Beata: Struktura i funkcjonowanie Szkoły Przemysłowo-Handlowej Sióstr Zmartwychwstania Pańskiego w Częstochowie w latach 1918-1939. W: Z dziejów Polski XIX i XX wieku. Księga jubileuszowa ofiarowana profesorowi Ryszardowi Szwedowi. Red. nauk. Tadeusz Dubiecki, Tadeusz Panecki. Częstochowa 2004 s. 105-110.

372. WIELEK Jan: Górska Szkoła Rolnicza w Łososinie Górnej (1929-1954). Rocz. Sqqdec. T. 33: 2005 s. 278-286.

\section{Zakłady kształcenia nauczycieli (z wyjątkiem szkół wyższych)}

373. HISTORYCZNE i współczesne konteksty kształcenia nauczycieli wczesnej edukacji. Pod red. Wiesławy Leżańskiej. Łódź 2004 Wyższa Szkoła Informatyki ss. 360, nlb. 2, il.

$\mathrm{Z}$ treści: Leżańska W.: Społeczne i polityczne konteksty kształcenia nauczycieli wychowania przedszkolnego w Polsce s. 9-22; Jakubiak Krzysztof: Pierwsze polskie podręczniki dla ochroniarek i freblanek z XIX i początków XX wieku s. 125-130; Stawiak-Ososińska Małgorzata: Przygotowanie zawodowe żeńskiego personelu pedagogicznego do pracy w ochronkach i żłobkach w Królestwie Polskim w pierwszej połowie XIX wieku s. 131-144; Wira-Swiątkowska Katarzyna: Kształcenie wychowawczyń przedszkoli w działalności Marii Weryho-Radziwiłłowiczowej [1858-1944] s. 151-156; Kamilewicz-Raczyńska Danuta: Historia działalności i znaczenie Seminarium Nauczycielskiego w Trokach (1924-1957) s. 157-177; Michalski Grzegorz: Dążenie SCHNNSP [Stowarzyszenie Chrześcijańsko-Narodowego Nauczycielstwa Szkół Powszechnych] do upowszechnienia wychowania przedszkolnego w dwudziestoleciu międzywojennym s. 179-188; Szczepańska Beata: Przygotowanie zawodowe nauczycieli szkół powszechnych w zakresie higieny szkolnej w dwudziestoleciu międzywojennym s. 189-201; Nowak Zbigniew: Urzędnik i żołnierz o potrzebie zmiany ethosu nauczycielskiego w Polsce s. 203-214; Radzikowska Dorota: Przygotowanie nauczycieli do kształcenia zintegrowanego w koncepcji Janiny i Antoniego Maćkowiaków s. 215-220; Magiera Elżbieta: Zadania nauczycieli szkół powszechnych w wychowaniu państwowym w Drugiej Rzeczypospolitej s. 221-235; Gawlik Stanisław: Kształcenie 
i dokształcanie nauczycieli w latach 1945-1948 s. 237-250; Pawelec Lidia: Walka o odnowę edukacji (1976-1987) s. 251-259.

374. KŁOS Elżbieta Alina: Historia i tradycje sennickich szkół pedagogicznych. Rocz. Mińsko-Maz. Z. 13: 2005 s. 27-47.

W 1. 1866-1994.

375. KUBIAK Katarzyna: Księgozbiór Liceum Pedagogicznego w Krotoszynie w zbiorach Książnicy Pedagogicznej im. Alfonsa Parczewskiego w Kaliszu. Katalog. Kalisz 2004 Kaliskie Tow. Przyj. Nauk ss. 118. Książnica Pedagog. im. A. Parczewskiego. (Katalogi i Bibliografie. $\mathrm{Nr} 10)$.

376. OŚKO Stanisław: Absolwenci Państwowego Liceum Pedagogicznego w Inowrocławiu (rocznik 1950), czyli Rzecz o etosie nauczycielskim. Radom 2005 Wydaw. Inst. Technologii Eksploatacji - PIB ss. 235, il. (Biblioteka Pedagogiki Pracy. T. 129).

377. [PIĘTNASTOLECIE] 15 lecie Nauczycielskiego Kolegium Języków Obcych w Kaliszu. 1990-2005. [Aut.] Małgorzata Wrotkowska, Wielisława Dankiewicz-Czajka, Anna Matysiak oraz nauczyciele NKJO. Kalisz 2005 Nauczycielskie Kolegium Języków Obcych ss. 95.

378. SZOT Adam: 25 lat kształcenia teologicznego katechetów w Białymstoku. Wiad. Kośc. Archidiec. Bialost. R. 11: 2002 nr 4 s. 229-258.

Studium Teologiczno-Katechetyczne, od 1978 r.

\section{Szkoły wyższe}

\section{Akademia Ekonomiczna w Krakowie}

379. DOKTORZY honoris causa. In perpetuam rei memoriam. Oprac. dokumentacji Zbigniew Paszek; oprac. red. tekstu w jęz. ang. oraz przekł. na jęz. ang. Jasper Tilbury. Kraków 2004 Wydaw. Akad. Ekonomicznej ss. 260, nlb. 1, il.

Jubileusz 80-lecia Akademii Ekonomicznej w Krakowie, 1925-2005.

Tekst równol. pol., ang.

\section{Akademia Górniczo-Hutnicza}

380. WÓJCIK Zbigniew [Jerzy]: Z dziejów starań o powołanie Akademii Górniczej w Krakowie. Pr. Komis. Hist. Nauki. T. 6: 2004 s. 45-58.

G1. w 1. 1912-1918; Uzup.: Dyskusja. Tamże s. 59-65.

\section{Akademia Medyczna w Gdańsku}

381. ZOSTAWIĆ ślad za sobą. Refleksje i wspomnienia z okazji 60-lecia Akademii Medycznej w Gdańsku. Pod red. Wiesława Makarewicza. Gdańsk 2005 Via Medica ss. 276, nlb. 12, il. 


\section{Akademia Muzyczna im. Fryderyka Chopina w Warszawie}

382. [TRZYDZIEŚCI] 30 lat Białostockiej Filii Akademii Muzycznej im. Fryderyka Chopina w Warszawie. 30 years of Fryderyk Chopin Warsaw Academy of Music Branch in Białystok. Kom. red. Leszek Sokołowski [i in.]; tł. na jęz. ang. Bogumił Jaworski, Małgorzata Konopko. Białystok-Warszawa 2004 Wydaw. Akad. Muzycznej im. F. Chopina w Warszawie. Filia w Białymstoku ss. 110 , il.

\section{Akademia Pedagogiczna im. Komisji Edukacji Narodowej w Krakowie}

383. GLOGIER Marek: Karta z dziejów 45-lecia Archiwum AP im. KEN w Krakowie. Annales $A P C$. Folia 25: Studia ad Bibliothecarum. [T.] 3: 2005 s. 223-232, abstr.

Od 1946 r.

\section{Akademia Połocka}

384. INGLOT Marek: Akademia Połocka (1812-1820) - jezuicka uczelnia na Białorusi. Zarys problematyki. W: W kręgu chrześcijańskich tradycji starego kontynentu. Praca zbior. pod red. Marcelego Kosmana. Poznań 2005 s. 57-78.

385. [KANDULSKA Irena] Kadul'skaja Irčna: Formy tčatral'naga žyccja u Polackaj Akadčměě (1812-1820). Belaruski Gistaryčny Agljad. T. 11: 2004 s”. 1/2 s. 157-197, streszcz.

\section{Akademia Rolnicza w Lublinie}

386. KSIĘGA pamiątkowa. 50-lecie Akademii Rolniczej w Lublinie. Red. Ewa Zawadzka-Mazurek, Ewa Różycka. Lublin 2005 Wydaw. AR ss. 165, nlb. 2, il. Akad. Rolnicza w Lublinie.

\section{Akademia Rolnicza we Wrocławiu}

387. DAĆ świadectwo Prawdzie. Historia „Solidarności” Akademii Rolniczej we Wrocławiu. Pod red. Jerzego Webera. Wrocław 2005 Akad. Rolnicza ss. 264, il.

Treść: Wstęp s. 9-10; Wprowadzenie s. 11-15; PZPR na uczelniach s. 16-31; Okres do 13 grudnia 1981 r. Powstanie Komisji Uczelnianej s. 32-49; Działalność związku do wprowadzenia stanu wojennego s. 50-70; Okres od 13 grudnia 1981 r. do 1989 roku. Strajk okupacyjny s. 71-98; Działalność konspiracyjna s. 99-115; Represje s. 116-149; Kolokwium habilitacyjne s. 150-155; Manifestacje uliczne s. 156-175; Działalność jawna s. 176-187; Emigracja i nowy wymiar „Solidarności” s. 188-197; Załączniki [fotokopie dokumentów] s. 198-250; Bibliografia s. 251 ; Kalendarium [1980-1989] s. 252-256. 


\section{Akademia Sztuk Pięknych w Warszawie}

388. WŁODARCZYK Wojciech: Akademia Sztuk Pięknych w Warszawie w latach 1944-2004. 100 lat Akademii Sztuk Pięknych w Warszawie. Warszawa 2005 Wydawnictwa Szkolne i Pedagog.; Akad. Sztuk Pięknych ss. 690, nlb. 2, il.

\section{Akademia Wychowania Fizycznego Józefa Piłsudskiego w Warszawie}

389. OD FILII do Wydziału Wychowania Fizycznego w Białej Podlaskiej. Zjazd absolwentów z okazji XXXV-lecia uczelni, 3-5 czerwiec 2005 r. Red. Teresa Jaślikowska-Sadowska. Biała Podlaska 2005 AWF Józefa Piłsudskiego w Warszawie. Zamiejscowy Wydz. Wychowania Fizycznego ss. 230, nlb. 1. AWF Józefa Piłsudskiego w Warszawie. Zamiejscowy Wydz. Wychowania Fizycznego w Białej Podlaskiej.

Z treści: Cicirko Zofia, Demidowicz Tomasz: Przegląd wydarzeń z życia uczelni (1969-2005) s. 11-22; Nałęcka Danuta: Wspomnienia pierwszych lat bielskiej uczelni wychowania fizycznego s. 25-31; Ujma Maria: Wspomnienia o bibliotece, ludziach i Związku Nauczycielstwa Polskiego s. 33-48; Jobda Zdzisław: AWF w mojej pamięci... s. 49-59; Starzyński Józef: Wspomnienia s. 61-63; Kałuża Krystyna: Wspomnienia młodego asystenta s. 65-67; Włostowska Kunegunda: Człowieczeństwo jako istotna wartość w relacji nauczyciel-uczeń s. 69-75; Suchożebrska Sławomira: Wspomnienia s. 77-84; Wyciszkiewicz Janusz: Wspomnienia „Wujka” s. 85-92; Gałecki Janusz: Krótkie reminiscencje mieszkańca akademika s. 93-97; Serafin-Cicirko Z.: Zatrzymane we wspomnieniach s. 99-105; Jaślikowska T.: To były piękne dni... s. 107-117; Żmigrodzka-Fernandes Maria: Wspomnienie z lat studenckich (1975-1979) s. 119-122; Dziaczkowski Waldemar: Wspomnienia s. 123-128; Sacharczuk Stanisław: To były czasy! s. 129-134; Jobda Marek: Wspomnienia s. 135-136; Cicirko Leszek: Rok 1977 s. 137-138; Szwiec Jan: Z pamiętnika absolwenta s. 139-146; Marańczak Jolka: Wspomnienia s. 147-153; Krakowiak Jacek: Moje wspomnienia s. 155-156; Frankowska Dorota: Z życia siatkarki s. 157; Bobowik Wiesław: Studencki klub „Meta” w latach 1980-1989 s. 163-165; Szoda Dariusz: Wspomnienia s. 171-176; Okapa Krzysztof: Wspomnienia ze studiów 1988-1992 s. 177-186.

\section{Centralna Szkoła Podoficerska Korpusu Ochrony Pogranicza}

390. SZCZEPAŃSKI Kajetan: Centralna Szkoła Podoficerska Korpusu Ochrony Pogranicza. W: Korpus Ochrony Pogranicza. Materiały z konferencji naukowej. Pod red. Jerzego Prochwicza. Kętrzyn 2005 s. 81-100.

\section{Chrześcijańska Akademia Teologiczna w Warszawie}

391. [PIĘĆDZIESIĄT] 50 lat Chrześcijańskiej Akademii Teologicznej w Warszawie. Red. Marek Ambroży. Warszawa 2005 ChAT ss. 140. Chrześcijańska Akad. Teol.

Z treści: Wysoczański Wiktor: Słowo Rektora s. 5-8; Maciuszko Janusz T.: Dzieje CHAT w latach 1954-1966 s. 9-29; Bendza Marian: Dzieje Chrześcijańskiej Akademii Teologicznej w latach 1966-1989 s. 31-81; Wysoczański W.: Dzieje Chrześcijańskiej Akademii Teologicznej w latach 1989-2004 s. 83-102; Władze s. 107-108; Doktorzy „honoris causa” Chrześcijańskiej Akademii Teologicznej s. 109-112; Doktoraty i habilitacje w Chrzescijańskiej Akademii Teologicznej w latach 1954-2004 s. 113-130; Bendza M.: Rocznik Teologiczny s. 131-138. 


\section{Collegium Augustianum w Grudziądzu}

392. SZAJERKA Marek: Szkoła biskupa misyjnego Prus św. Chrystiana - przyczynek do dziejów szkolnictwa wyższego w Polsce. Piotrk. Zesz. Hist. T. 5: 2003 s. 63-93, sum.

Collegium Augustianum w Grudziądzu w 1. 1218-1772.

\section{Katolicki Uniwersytet Lubelski}

393. Z NASZEGO półwiecza. Wspomnienia absolwentów filologii polskiej Katolickiego Uniwersytetu Lubelskiego rocznik 1951-1955. Pod red. Bohdana Królikowskiego. Lublin 2005 Wydaw. KUL ss. 411, tabl. 22, il.

\section{Państwowa Wyższa Szkoła Zawodowa w Koninie}

394. ORCZYK Józef: Państwowa Wyższa Szkoła Zawodowa w Koninie. Lata 1998-2004. Rocz. Konin. T. 15: 2005 s. 301-310.

\section{Papieska Akademia Teologiczna}

395. KUBIŚ Adam: Papieski Wydział Teologiczny w Krakowie w latach 1954-1981. Red. nauk. Stanisława Postawa. Kraków 2005 Wydaw. Nauk. PAT ss. 520, tabl. 18, il. PAT w Krakowie. (Studia do Dziejów Wydziału Teologicznego Uniwersytetu Jagiellońskiego. Studia Res Gestas Facultatis Theologicae Universitatis Jagiellonicae Illustrantia. T. 18).

\section{Politechnika Gdańska}

396. PIONIERZY Politechniki Gdańskiej. Kom. red. Zygmunt Paszota, Janusz Rachoń, Edmund Wittbrodt. Gdańsk 2005 Politech. Gdańska ss. 770, il.

Treść: Rachoń J.: Słowo wstępne s. 5-7; Oddajmy głos pionierom. Droga do Politechniki Gdańskiej. Otto Franciszek: W stronę minionych dni i zdarzeń s. 9-13; Kopecki Kazimierz: Ostatnia rozmowa z Profesorem. (Rozm. Danuta Siemińska) s. 14-18; Początki... Otto F.: Pierwsze dni s. 19-20; Wiśniewski Jerzy: Zapisane w pamięci s. 21-24; Turski Stanisław: Notatka o Politechnice Gdańskiej s. 25-28; Rylke Aleksander: Znów wśród swoich s. 29-33; Szewalski Robaert: Przybyłem do Gdańska s. 34-36; To ludzie tworzyli tę uczelnię. Adamczewski Ignacy: Moje początki w Politechnice Gdańskiej s. 37-41; Hueckel Stanisław: Inżynierskie wspomnienia s. 42-46; Nowacki Witold: Notatki autobiograficzne s. 47-50; Pierwsze inauguracje. Rylke A.: Chwila, którą przeżywamy, jest chwilą epokową... s. 53-55; Hueckel S.: Niezapomniana inauguracja s. 56; Huber Maksymilian Tytus: Technika współczesna a wiedza przyrodnicza s. 57-65; Bohaterowie tamtych dni [biogramy ze zdjęciami oraz artykuły] s. 69-760; Walczyli, budowali, tworzyli. (Oprac. Wojciech Winiarski) s. 761-763.

397. WYDZIA£ Mechaniczny Politechniki Gdańskiej w latach 1945-2005. Monografia historyczno-biograficzna. Red. Adam Barylski; współpr. Mieczysław Feld, Andrzej Wróblewski. Gdańsk 2005 Wydz. Mechaniczny Politech. Gdańskiej ss. 484, il. 


\section{Politechnika Krakowska}

398. POLITECHNIKA Krakowska w latach 1995-2005. Jubileusz 60-lecia Politechniki Krakowskiej im. Tadeusza Kościuszki. Red. merytoryczny Kazimierz Flaga. Kraków 2005 Wydaw. PK ss. 358 , il.

\section{Politechnika Śląska w Gliwicach}

399. SITKO Wojciech: Historia Wydziału Budownictwa Politechniki Śląskiej w Gliwicach. Gliwice 2004 Wydaw. Politech. Śląskiej ss. 226, nlb. 1, il.

\section{Politechnika Wrocławska}

400. ABSOLWENCI. Losy absolwentów Politechniki Wrocławskiej, którzy rozpoczęli studia na Wydziale Elektrycznym w roku 1949. Uzupełnienie. Zebr. i oprac. Jan Pytel i Andrzej Kostowski. Wrocław 2005 Oficyna Wydawnicza Politech. Wrocławskiej ss. 90, il. Stow. Absolwentów Politech. Wrocławskiej, Politech. Wrocławska.

Uzupehnienie do pracy z 2004 r.

401. POLITECHNIKA Wrocławska 1945-1951. Wybór źródeł. [Oprac.] Barbara Brandt-Golecka, Marek Burak, Gabryela Januszewska. Wrocław 2005 Oficyna Wydawnicza Politech. Wrocławskiej ss. 298, il.

\section{Szkoła Podchorążych Sanitarnych}

402. DUTKIEWICZ Marek: Sprawozdanie z sesji naukowej i wystawy: „Była taka podchorążówka w Warszawie. Wychowankowie Szkoły Podchorążych Sanitarnych 1922-2001", która odbyła się w Warszawie na Zamku Ujazdowskim w dniu 28 VI 2001 r. Piotrk. Zesz. Hist. T. 5: 2003 s. $469-470$.

\section{Uniwersytet im. Adama Mickiewicza}

403. SKOCZYŃSKI Bogumił: Universal'naja akademiseskaja Biblioteka Poznanskogo Universiteta - ot biblioteki pečatnych fondov k biblioteke elekronnych resursov. Biblioteka. $\mathrm{Nr}$ 9: 2005 s. 111-140, abstr. s. 9 .

\section{Uniwersytet Jagielloński}

404. BIALEK Danuta: Mieszkańcy Wodzisławia Śląskiego na Uniwersytecie Jagiellońskim od XV do połowy XVI wieku. Pr. Uczes. Stud. Dokt.. [T.] 5: Historia: 2003 s. 39-47. 
405. DYBIEC Julian: Popularyzacja dziejów Uniwersytetu Jagiellońskiego. W: Przestrzeń informacji i komunikacji społecznej. Pod red. Marii Kocójowej. Kraków 2004 s. 323-332.

406. GĄSIOROWSKI Antoni: Pierwsi studenci odnowionego Uniwersytetu Krakowskiego (1400/1401). Rocz. Hist. R. 71: 2005 s. 63-98, Zsfg.

407. LASKA Andrzej, Pollesch Jolanta: Nabytki i konserwacja w Muzeum Uniwersytetu Jagiellońskiego w roku 2004. Zesz. Nauk. UJ. [Nr] 1277: Opuscula Musealia. Z. 14: 2005 s. 131-134, abstr.

408. LOPATKIEWICZ Tadeusz: Kolekcja szkicowników uczniów krakowskiej Szkoły Sztuk Pięknych w zbiorach Muzeum Uniwersytetu Jagiellońskiego. Nieznane rysunki S. Wyspiańskiego, J. Mehoffera $\mathrm{i}$ innych z wycieczek z W[ładysławem] Łuszczkiewiczem w latach 1888-1892. Zesz. Nauk. UJ. [Nr] 1277: Opuscula Musealia. Z. 14: 2005 s. 41-88, sum.

409. MARKOWSKI Mieczysław: Uniwersytet Krakowski w kontekście środkowoeuropejskim późnego średniowiecza i wczesnej nowożytności. Olecko 2005 Wydaw. Wszechnicy Mazurskiej ss. 650, il. (Acta Universitatis Masuriensis) (Episteme. [T.] 40).

410. PIETRZYK Zdzisław: Profesorowie Akademii Krakowskiej wobec reformacji w XVI wieku. W: Mikołaj Rej z Nagłowic w pięćsetną rocznicę urodzin. Pod red. Waldemara Kowalskiego. Kielce 2005 s. 277-286.

411. RELACJE pracowników Uniwersytetu Jagiellońskiego o ich losach osobistych i dziejach uczelni w czasie drugiej wojny światowej. Oprac. Jerzy Michalewicz. Kraków 2005 Archiwum UJ; Secesja ss. XCVIII, nlb. 2, 1091. (Z Prac Archiwum Uniwersytetu Jagiellońskiego. Ser. F, Varia. T. 5).

412. STARNAWSKI Jerzy: „Risum teneatis amici?” - drugi cykl anegdot o krakowskich profesorach po artykule Tadeusza Ulewicza. Biul. BJ. R. 44: 2004 [dr.:] 2005 s. 303-311.

W nawiązaniu do artykułu T. Ulewicza, Tamże. R. 43: 2003 [dr.:] 2004.

Anegdoty o profesorach UJ, XIX-XX w.

413. STOPKA Krzysztof: Głos w dyskusji nad fundacją uniwersytetu w Krakowie. Rocz. Krak. T. 71: 2005 s. 31-40, sum.

414. ZABLOCKI Wiesław: Co o nas wiedzieli? NSZZ „Solidarność” Uniwersytetu Jagiellońskiego w dokumentach SB. Kraków 2005 Arcana ss. 258. (Arkana Historii).

Wybór dokumentów.

415. WALTOŚ Stanisław: Collegium Maius Uniwersytetu Jagiellońskiego. Dzieje i przewodnik po zbiorach Muzeum. Tekst ...; fot. Janusz Podlecki. Wyd. 2 popr. i uzup. Kraków 2005 Wydaw. „Karpaty” - Andrzej Lączyński ss. 63, nlb. 1, il.

Wyd. 1. 1999.

\section{Uniwersytet Lwowski}

416. CIARA Stefan: Nauki pomocnicze historii na Uniwersytecie Lwowskim (1867-1918). W: Wielokulturowe środowisko historyczne Lwowa w XIX i XX w. T. 3. Pod red. Jerzego Maternickiego, Leonida Zaszkilniaka. Rzeszów 2005 s. 175-198. 
417. PISULIŃSKA Joanna: Sprawa obsadzenia katedry historii Polski na UJK w 1936 r. W: Wielokulturowe środowisko historyczne Lwowa w XIX i XX w. T. 3. Pod red. Jerzego Maternickiego, Leonida Zaszkilniaka. Rzeszów 2005 s. 441-454.

418. SZULAKIEWICZ Władysława: Dzieje nauczania historii oświaty i wychowania w Uniwersytecie Jana Kazimierza we Lwowie. Acta UNC. Nauki Hum.-Społ. Z. 365: Pedagogika. [Nr] 23: Historia Wychowania. 2004 s. 9-30.

W dwudziestoleciu międzywojennym.

\section{Uniwersytet Marii Curie-Skłodowskiej}

419. „SOLIDARNOŚĆ” Uniwersytetu Marii Curie-Skłodowskiej 1980-2005. Red. Marek Jędrych [i in.]. Wyd. 2 popr. i rozsz. Lublin 2005 NSZZ „Solidarnośč” Uniw. Marii Curie-Skłodowskiej; BiS - Zakł. Poligraficzny ss. 246, nlb. 2, il.

Treśc: Kaczor Józef: Zamiast wstępu - historia jednego wiersza s. 5-7; Trześniowski Dariusz: To już 25 lat... s. 9-10; XXV lat „Solidarności” UMCS: 1980-1981 s. 11-48; 1981-1989 s. 49-63; 1989-2005 s. 65-96; Zespoły, Komitety, Komisje s. 97-102; Uchwały Zakładowych Zebrań Delegatów NSZZ „Solidarnośé" UMCS s. 103-120; Krajowa Sekcja Nauki s. 121-128; Regionalna Sekcja Nauki Regionu Środkowowschodniego NSZZ „Solidarność" s. 129-133; Dzień dzisiejszy s. 135-142; Materiały do historii NSZZ „Solidarność” UMCS s. 143-218; Komentarze s. 219-224; Sylwetki s. 225-246.

Wyd. 1. 2000.

\section{Uniwersytet Mikołaja Kopernika}

420. MARKIEWICZ Małgorzata: Absolwenci studium archeologii Uniwersytetu Mikołaja Kopernika w latach 2000-2003. Acta UNC. Nauki Hum.-Społ. Z. 370: Archeologia. [Nr] 29: Archeologia szkła. [T.] 9. 2005 s. 285-302.

Spisy.

421. PSZCZÓŁKOWSKI Michał: Przegląd piśmiennictwa do dziejów budowy campusu UMK. Rocz. Tor. [T.] 32: 2005 s. 237-244.

Od 1967 r.

\section{Uniwersytet Opolski}

422. GAJDA Stanisław: Ku Uniwersytetowi Opolskiemu. Kw. Opol. R. 50: $2004 \mathrm{nr} 1$ s. $143-148$.

Lata 1986-1994.

423. NICIEJA Stanisław Sławomir: Alma Mater Opoliensis. Ludzie, fakty, wydarzenia. Księga jubileuszowa w 50. rocznicę Wyższej Szkoły Pedagogicznej w Opolu i 10. rocznicę powstania Uniwersytetu Opolskiego. Opole 2005 Wydaw. UO ss. 504, il. Uniw. Opolski.

424. PIASECKI Zbigniew: Karta z dziejów Wydziału Filologicznego Uniwersytetu Opolskiego. Kw. Opol. R. 50: $2004 \mathrm{nr} 1$ s. 149-152.

Okoliczności powstania w $1996 \mathrm{r}$. 
425. [TRZYDZIEŚCI] 30 lat opolskiej pedagogiki. Przygot. zespół w składzie Józef Brągiel [i in.]. Opole 2004 Wydaw. Uniw. Opolskiego ss. 238, il. Inst. Nauk Pedagog., Inst. Studiów Edukacyjnych Uniw. Opolskiego.

\section{Uniwersytet Warszawski}

426. MIZIOŁEK Jerzy: Uniwersytet Warszawski. Dzieje i tradycja. Warszawa 2005 Wydaw. Uniw. Warszawskiego ss. 324, nlb. 2, il.

Toż. Wyd. 2 zm. i popr. Warszawa 2005 ss. 324, nlb. 2, il.

427. MRÓZ Lech, Sokolewicz Zofia: Etnografia, etnologia, antropologia kulturowa w Uniwersytecie Warszawskim od 1935 roku do dziś. Nauka Pol. - Potrz. Org. [T.] 14: 2005 s. 77-109, sum.

428. SAMSONOWICZ Henryk: Seminarium Mariana Małowista. Prz. Hist. T. 96: 2005 z. 2 s. $195-203$.

W 1. 1946-1988 (z przerwami).

429. SCHILLER Joanna: Materiały do dziejów Cesarskiego Uniwersytetu Warszawskiego w Rostowie nad Donem. Nauka Pol. - Potrz. Org. [T.] 14: 2005 s. 237-245.

W Państwowym Archiwum Obwodu Rostowskiego.

430. SCHILELR J.: Uniwersytet Warszawski - czy uniwersytet i czy w Warszawie?. Kw. Hist. Nauki i Techn. R. 50: 2005 nr 3/4 s. 25-58, sum.

Dzieje uczelni w 1. 1816-1917.

431. TRADYCJE i współczesność. Księga pamiątkowa Instytutu Historycznego Uniwersytetu Warszawskiego, 1930-2005. Red. Grażyna Raj, Izabela Komorowska. Warszawa 2005 DiG ss. 799, nlb. 1, il.

Rec.: Bieńkowski Tadeusz, Kw. Hist. Nauki i Techn. R. 50: 2005 nr 3/4 s. 263-266.

432. WYDZIAI Pedagogiczny Uniwersytetu Warszawskiego. Jubileusz pięćdziesięciolecia. Pod red. Janiny Kamińskiej. Warszawa 2004 Wydaw. UW ss. 307, nlb. 1.

Treść: Kamińska J.: Dzieje Wydziału Pedagogicznego Uniwersytetu Warszawskiego. Zarys s. 7-48; Billik Bogdan: Wywiad z Profesor Anną Mońką-Stanikową s. 49-52; Izdebski Zbigniew: Wywiad z Profesorem Andrzejem Jaczewskim s. 53-59; Mieszalski Stefan: Wywiad z Profesorem Czesławem Kupisiewiczem s. 61-67; Siemiak-Tylikowska Alicja: Wywiad z Profesorem Wincentym Okoniem s. 69-83; Świerczyńska-Jelonek Danuta: Wywiad z Profesor Anną Przecławską s. 85-97; Pankowska Krystyna: Wywiad z Profesor Ireną Wojnar s. 99-117; Rotkiewicz Halina: Wywiad z Profesorem Stefanem Wołoszynem s. 119-125; Ruszczyńska Maria: Wywiad z Profesorem Władysławem Piotrem Zaczyńskim s. 127-129; Woynarowska Barbara: Katedra Biomedycznych Podstaw Rozwoju i Wychowania Wydziału Pedagogicznego Uniwersytetu Warszawskiego. Działalność w latach 1997-2003 s. 131-143; Zaczýnski Władysław Piotr: Dydaktyka ogólna w Uniwersytecie Warszawskim s. 145-153; Słodownik-Rycaj Ewa, Żytko Małgorzata: Katedra Edukacji Początkowej - 30 lat istnienia s. 155-163; Katedra Edukacji Ustawicznej i Andragogiki. Geneza, losy i stan obecny s. 165-181; Szybiak Irena: Katedra Historii Oświaty i Wychowania (1953-2003) s. 183-226; Mońka-Stanikowa Anna: Katedra Pedagogiki Porównawczej na Wydziale Pedagogicznym Uniwersytetu Warszawskiego s. 227-231; Dryżałowska Grażyna: Pedagogika specjalna na Wydziale Pedagogicznym Uniwersytetu Warszawskiego s. 233-240; Theiss Wiesław: Katedra Pedagogiki Społecznej Wydziału Pedagogicznego Uniwersytetu Warszawskiego (1957-2003) s. 241-259; Frączek Adam: Historia (bardzo krótka) i dokonania Katedry Psychologii Edukacji Wydziału Pedagogicznego UW s. 261-266; Kwiatkowska Henryka: Z działalności Pracowni Pedeutologii Wydziału Pedagogicznego UW s. 267-268; Malicka Małgorzata, Depta Henryk: 35 lat działalności Zakładu/Pracowni Teorii Wychowania Estetycznego s. 269-291; Kołacz Krzysztof, Kordiał Agnieszka: Studenckie konferencje naukowe Specjalizacji Andragogicznej s. 293-308.

Rec.: Szulakiewicz Władysława, Rozpr. Dziej. Ośw. T. 43: 2004 s. 233-234. 


\section{Uniwersytet Wileński}

433. MASSONIUS Marian Piotr: Dzieje Uniwersytetu Wileńskiego 1781-1832. Notatki z wykładów w roku akademickim 1924/1925. Do dr. przygot., przypisami, szkicami uzupełniającymi i posłowiem opatrzyli Anna Supruniuk, Mirosław Adam Supruniuk. Torun 2005 Bibl. Uniwersytecka; Wydaw. UMK ss. 146, nlb. 1, tabl. 16, il., streszcz. lit. (Materiały do Tradycji Uniwersytetu Mikołaja Kopernika w Toruniu. [T.] 1).

434. PRAĐMANTAITË Aldona: Posiedzenia publiczne Uniwersytetu Wileńskiego (1803-1832) - formą popularyzacji wiedzy naukowej wśród społeczeństwa ziem byłego Wielkiego Księstwa Litewskiego. Echa Przeszłości. [T.] 6: 2005 s. 71-85, sum.

435. TYLIŃSKA Ewelina: Popularyzacja wiedzy na Uniwersytecie Stefana Batorego a życie kulturalne w międzywojennym Wilnie. Rozpr. Dziej. Ośw. T. 44: 2005 s. 137-149, sum.

\section{Uniwersytet Wrocławski}

436. BIBLIOTECZKA Wydziału Prawa, Administracji i Ekonomii Uniwersytetu Wrocławskiego 1961-2005. Historia, organizacja, działalność. Red. nauk. Maria Pidłypczak-Majerowicz. Wrocław 2005 Wydaw. Uniw. Wrocławskiego ss. 239, tabl. 16, il.

Z treści: Górna Bożena, Mroczko-Sidorowicz Joanna: Wstęp s. 9-12; Górna B.: Z kart historii s. 23-71; Górna B.: Wydziałowa Komisja Biblioteczna s. 72-88; Juchniewicz Tadeusz: Konserwacja i ochrona księgozbioru s. 167-178; Juchniewicz T.: Działalność informacyjna s. 179-186; Bibliografia s. 200-202; Aneks [Dokumenty dotyczące działalności Biblioteki w l. 1961-2005] s. 205-239.

\section{Wszechnica Mazurska}

437. DZIESIĘĆ lat Wszechnicy Mazurskiej w Olecku. Red. Józef Krajewski, Jarosław Sokołowski. Olecko 2001 Wydaw. Wszechnicy Mazurskiej ss. 232, il., sum. (Acta Universitatis Masuriensis) (Episteme. [Vol.] 18).

\section{Wyższe Seminarium Duchowe w Płocku}

438. GRZYBOWSKI Michał Marian: Mądrość zbudowała sobie dom. 75-lecie Biblioteki Wyższego Seminarium Duchowego w Płocku, 1928-2003. Płock 2004 Kronos ss. 117, nlb. 2, tabl. 16, il.

Rec.: Nowicki Ryszard, Biblioteka. Nr 9: 2005 s. 225-228.

Wyższe Seminarium Duchowne w Dębowcu

439. WISZ Piotr: Wyższe Seminarium Duchowne Misjonarzy Matki Bożej z La Salette w Dębowcu (1952-1955). Resovia Sacra. R. 11: 2004 s. 161-181, sum. 
440. NOWICKI Ryszard: Trzy listy ks. Stefana Wyszyńskiego i ks. Franciszka Karszyńskiego z lat 1945-1946 w sprawie rewindykacji Biblioteki Wyższego Seminarium Duchownego we Włocławku. Studia Gnesnensia. T. 18: 2004 s. 263-270.

441. PONIŃSKI Antoni: Ingerencje władz PRL w działalność dydaktyczną Wyższego Seminarium Duchownego we Włocławku. Studia Wtoc. T. 8: 2005 s. 337-354.

Lata 1949-1967.

Wyższe Seminarium Duchowne Zakonu Paulinów

442. WYŻSZE Seminarium Duchowne Zakonu Paulinów. 350 lat studium filozoficzno-teologicznego w Krakowie na Skałce (1653-2003). Praca zbior. pod kier. Andrzeja Napiórkowskiego, Mariusza Tabulskiego. Częstochowa-Kraków 2004 Paulinianum. Wydaw. Zakonu Paulinów ss. 160 , nlb. 8 , tabl. 19 , il.

\section{BIOGRAFIE}

\section{Zbiory życiorysów}

443. GRĘDZIK-RADZIAK Agnieszka: Polscy nauczyciele z ziem południowo-wschodnich II Rzeczypospolitej - ofiary zbrodni sowieckich w latach 1939-1941 deportowani, więzieni, zamordowani (cz. 1). Prz. Hist.-Ośw. R. 48: 2005 nr 3/4 s. 217-266.

444. REKTORZY państwowych wyższych uczelni w Łodzi 1945-2002. Uniwersytet Łódzki, Politechnika Łódzka, Akademia Medyczna, Wojskowa Akademia Medyczna, Akademia Sztuk Pięknych, Akademia Muzyczna, Państwowa Wyższa Szkoła Filmowa, Telewizyjna i Teatralna, Wyższe Seminarium Duchowne. Suplement [do wyd. z 2002 r.]. Red. Elżbieta Paradowska. Eódź 2004 Łódzkie Tow. Nauk. ss. 43, il.

Wyd. 2, rozsz. i uzup. Rektorzy państwowych wyższych uczelni w Łodzi 1945-2005. Łódź 2005 ss. 357, il.

445. SŁOWNIK biograficzny nauczycieli zasłużonych dla oświaty i Związku Nauczycielstwa Polskiego w powiecie Mińsk Mazowiecki. Z. 1. Zespół red. Krystyna Aksman [i in.]. Mińsk Mazowiecki 2005 Poligrafia Wydaw. „Żelazo” ss. 319, il. Zarząd Oddz. ZNP w Mińsku Mazowieckim. Oddziałowa Komisja Hist.

446. ZABORNY Piotr: Portrety wychowawców do służby państwu. Skierniewice 2005 Sigma ss. 130 . 


\section{Poszczególne biografie}

\section{Bielski Kazimierz}

447. PROFESOR Kazimierz Bielski [1860-1939]. Materiały biograficzne. Pod red. Jana Kazimierza Sawickiego. Gdynia 2003 Akad. Morska. Pracownia Historii; zlec. Wydz. Mechaniczny Akad. Morskiej ss. 32, il.

Treść: Mielczarek Ryszard: Biografia Kazimierza Bielskiego s. 5-8; [Chrząszczewska Anna]: Biografia profesora Kazimierza Bielskiego w zapisie wnuczki Anny Chrząszczewskiej. Oprac. J. K. Sawicki s. 9-19; Profesor Kazimierz Bielski w opinii absolwentów Szkoły Morskiej w Tczewie i Gdyni. Wybór tekstów: Daniel Duda i J. K. Sawicki s. 20-26; Książki i skrypty autorstwa Kazimierza Bielskiego s. 27.

\section{Brzostowski Karol}

448. WYSOCKI Kazimierz, Wojciechowska Ilona: Hrabia Karol Brzostowski [1786-1854] jako społecznik, organizator życia gospodarczego oraz promotor oświaty na Augustowszczyźnie w okresie Królestwa Polskiego. Gdań. Zap. Hist.-Spot. T. 1: 2004 [dr.:] 2005 s. 104-118, sum., streszcz.

\section{Cieszkowski August}

449. ŚWIDZIŃSKI Jerzy: Cieszkowski [1814-1894] jako pedagog. W: Duch wielki, serce złote. August Cieszkowski - jego intelektualna i materialna spuścizna. Zespół red. Andrzej Kurowski (przewodn.), Ewa J. Buczyńska, Włodzimierz Buczyński. Swarzędz 2004 s. 67-72.

\section{Cioch Bronisław}

450. POLEWIAK Małgorzata, Polewiak Maciej: Bronisław Cioch [1946-1997] - działacz Związku Nauczycielstwa Polskiego na Opolszczyźnie. Pr. Uczes. Stud. Dokt. [T.] 5: Historia: 2003 s. 131-148.

\section{Ćwikowski Franciszek}

451. PUDŁOWSKI Tomasz: Nieznany kierownik Gimnazjum w Przemyślu na Zasaniu - Franciszek Ćwikowski [1881-1924]. Rocz. Przem. R. 40: 2004 z. 3 s. 93-97.

\section{Damrot Konstanty}

452. KUKOWSKA Monika, Pięta Ewa: Konstanty Damrot [1841-1895] - ksiądz, poeta, nauczyciel. Patron szkoły w Lubecku. Lubecko 2005 Zespół Szkół ss. 71, tabl. 16, il. 


\section{Danysz Antoni}

453. MEISSNER Andrzej: Antoni Danysz (1853-1925) i jego miejsce w kształtowaniu się historii wychowania. W: Wielokulturowe środowisko historyczne Lwowa w XIX i XX w. T. 3. Pod red. Jerzego Maternickiego, Leonida Zaszkilniaka. Rzeszów 2005 s. 285-295.

\section{Dibbelt Otto}

454. SKRZYPEK Ignacy: Dr Otto Dibbelt [1881-1956] - pedagog, badacz ziemi kołobrzeskiej i muzealnik. W: Dzieje wsi pomorskiej. II Międzynarodowa Konferencja Naukowa, Włościbórz, gmina Dygowo, powiat kołobrzeski, 23-24 maja 2003. Materiały. Pod red. Radosława Gazińskiego i Andrzeja Chludzińskiego. Dygowo-Szczecin 2003 s. 57-74.

\section{Jabłoński Pius}

455. KOWALSKI Robert: Życie i działalność konspiracyjna Piusa Jabłońskiego [1908-1979] w latach wojny i okupacji. Orawa. R. 16/17: 2005 s. 119-128.

456. MADEJA Andrzej: Dyrektor Pius Jabłoński - szlachetny nauczyciel i wychowawca (1908-1979). Wspomnienie. Orawa. R. 16/17: 2005 s. 129-136.

\section{Józef Sebastian Pelczar, św.}

457. PERKOWSKA Urszula: Działalność uniwersytecka ks. Józefa Sebastiana Pelczara w Krakowie. W: Święty Józef Sebastian Pelczar (1842-1924). Rektor Uniwersytetu Jagiellońskiego i biskup przemyski. Przewodn. zespołu red. Adam Kubiś. Kraków 2005 s. 477-489.

\section{Kamiński Aleksander}

458. HARCMISTRZ Aleksander Kamiński [1903-1978] - wizja społeczeństwa obywatelskiego. Konferencja Związku Harcerstwa Polskiego, Muzeum Harcerstwa pod patronatem Marszałka Sejmu RP, Warszawa 21 XI 2003 r. Materiały pokonferencyjne. Pod red. Andrzeja Janowskiego. Warszawa 2004 Horyzonty; Muzeum Harcerstwa ss. 94, nlb. 1, tabl. 4, il. (Przed Stuleciem Harcerstwa).

Z treści: Borodzik Andrzej: Wstęp s. 5-10; Janowski A.: Wizja człowieka i społeczeństwa w pismach Aleksandra Kamieńskiego s. 22-28; Straszewska Maria: Wojenna warszawska droga Aleksandra Kamieńskiego s. 29-41.

\section{Konarski Stanisław}

459. STANISŁAW Konarski [1700-1773]. Pedagog, polityk, filozof. Mowa o potrzebie kształtowania od najmłodszych lat uczciwego człowieka i dobrego obywatela. Materiały z konfe- 
rencji naukowej. Uniwersytet Warszawski 2001. Pod red. Jadwigi Ziętarskiej. Warszawa 2004 Nakl. Wydz. Polonistyki Uniw. Warszawskiego ss. 120.

$\mathrm{Z}$ treści: Konarski Stanisław: Mowa o potrzebie kształtowania od najmłodszych lat uczciwego człowieka i dobrego obywatela s. 9-51; Kryda Barbara: Konarski - wychowawca i nauczyciel s. 55-70.

\section{Kralczyński Kazimierz}

460. STĘPIEŃ Bogdan: Kazimierz Kralczyński (1840-1882). Lekarz, społecznik, założyciel i wieloletni prezes Towarzystwa Oświaty „Mrówka” w Lańcucie. Pr. Hist.-Archiw. T. 15: 2005 s. 187-196.

Zawiera też: Wykaz publikacji K. Kralczyńskiego z lat 1865-1879.

\section{Lutosławski Wincenty}

461. BILIŃSKI Piotr: Spory Wincentego Lutosławskiego [1863-1954] z Uniwersytetem Jagiellońskim. Kw. Hist. Nauki i Techn. R. 50: 2005 nr 2 s. 203-229, sum.

\section{Maciejonczyk Paweł}

462. PRZELIORZ Zofia: Paweł Maciejonczyk [1913-2003] nauczyciel, wychowawca młodzieży, miłośnik gór, społecznik. W: Osiny w latach 1305-2005. Przewodn. kol. red. Lucjan Buchalik; oprac. tekstów Marek Baster. Żory 2005 s. 145-148.

\section{Madejski Józef}

463. WOLNICKI Paweł: Działalność wychowawcza i pisarska Józefa Madejskiego (1691-1748). Częst. Studia Teol. [T.] 32: 2004 [dr.:] 2005 s. 289-307.

\section{Mauersberg Stanisław}

464. WALCZAK Marian: Życie, działalność pedagogiczna i naukowa profesora Stanisława Mauersberga (w osiemdziesiątą rocznicę urodzin). Prz. Hist.-Ośw. R. 48: 2005 nr 1/2 s. 163-165.

\section{Nowak Stanisław}

465. ŚCIGALSKA Barbara: Twórca i założyciel Związku Nauczycielstwa Polskiego. Krak. Studia Matopol. Nr 9: 2005 s. 331-334.

Stanisław Nowak (1859-1936). 


\section{Papiewska Maria}

466. DOROSZEWSKI Jerzy: Zasługi Marii Papiewskiej [1859-1942] dla kształtowania i rozwoju wychowania przedszkolnego w Polsce międzywojennej. Prz. Hist.-Ośw. R. 48: $2005 \mathrm{nr}$ 1/2 s. 173-186.

\section{Rowid Henryk}

467. KROCHMALSKA-GAWROSIŃSKA Ewa: Henryk Rowid [1877-1944] - kreator idei pedagogicznych w Polsce okresu Dwudziestolecia Międzywojennego. Piotrków Trybunalski 2005 Nauk. Wydaw. Piotrkowskie przy Filii Akad. Świętokrzyskiej ss. 415, il. Akad. Świętokrzyskiej im. J. Kochanowskiego w Kielcach. Filia w Piotrkowie Trybunalskim.

\section{Sobczak Andrzej}

468. MAGIERA Elżbieta: Andrzej Sobczak (1905-1979) nauczyciel i księgarz. Szczecin 2005 Wydaw. Nauk. Uniw. Szczecińskiego ss. 197, il., sum. Uniw. Szczeciński. (Rozprawy i Studia. T. 585(659)).

\section{Sokołowski Janusz}

469. WIŚNIEWSKI Andrzej: Profesor Janusz Sokołowski [1921-1997] pierwszy rektor Uniwersytetu Gdańskiego. Oprac. ... Gdańsk 2005 Wydaw. Uniw. Gdańskiego ss. 177, nlb. 3, il.

\section{Suligowski Adolf}

470. KOREDCZUK Bożena: Działalność oświatowa i biblioteczna adwokata Adolfa Suligowskiego [1849-1932] w okresie zaborów. Rocz. Bibliot. R. 49: 2005 s. 423-436, sum.

\section{Szelągowski Adam}

471. MATERNICKI Jerzy: Początki kariery profesorskiej Adama Szelągowskiego na Uniwersytecie Lwowskim (1909-1919). W: Historyk i historia. Studia dedykowane pamięci prof. Mirosława Francicia. Red. Adam Walaszek, Krzysztof Zamorski. Kraków 2005 s. 115-127.

\section{Tidicaeus Franciszek}

472. DREIKOPEL Tomasz: Życie i działalność naukowa Franciszka Tidicaeusa (1554-1617), fizyka miejskiego i profesora Gimnazjum Akademickiego w Toruniu. Rocz. Tor. [T.] 32: 2005 s. 23-50, sum., Zsfg. 


\section{Werner Wacław}

473. WASIAK Marek: Wacław Werner (1879-1948) - fizyk i dydaktyk. Prz. Hist.-Ośw. R. 48: $2005 \mathrm{nr} 3 / 4$ s. $267-274$.

\section{Wołoszyn Stefan}

474. ŻUKOWSKA Zofia: Pamięci profesora Stefana Wołoszyna. Prz. Hist.-Ośw. R. 48: 2005 nr $1 / 2$ s. $167-172$.

\section{Wrzoł Ludwik}

475. NOCOŃ Arkadiusz: Ks. Ludwik Wrzoł (1881-1940), pedagog, tłumacz, męczennik z Gusen. Śl. Studia Hist.-Teol. T. 38: 2005 z. 2 s. 464-470, argum.

\section{Zielonka Stefan}

476. ZIELONKA Małgorzata: Stefan Zielonka [1937-1983]. Nauczyciel z Osin. W: Osiny w latach 1305-2005. Przewodn. kol. red. Lucjan Buchalik; oprac. tekstów Marek Baster. Żory 2005 s. $164-165$.

\section{DZIEJE OŚWIATY POZASZKOLNEJ}

\section{Oświata dorosłych}

477. MARECKI Edward: Zarys Dziejów Szkoły dla Pracujących Nr 1 w Bydgoszczy 1945-2005. Bydgoszcz 2005 Piotr Kożuchowski ss. 63, nlb. 1, il.

478. SADOWSKA Joanna: Uniwersytety Robotnicze ZMS - szlachetna idea czy narzędzie indoktrynacji? Prz. Hist.-Ośw. R. 48: $2005 \mathrm{nr}$ 1/2 s. 5-29.

\section{Biblioteki}

479. [CZTERDZIEŚCI] 40 lat Pedagogicznej Biblioteki Wojewódzkiej w Katowicach Filii w Sosnowcu 1964-2004. Oprac. zespół pracowników PBW Filii w Sosnowcu pod red. Anny Białej. Sosnowiec 2004 Pedagog. Bibl. Woj. w Katowicach. Filia ss. 88, tabl. 2, il. 
480. DZIENIAKOWSKA Jolanta: Biblioteki kieleckich publicznych szkół podstawowych i gimnazjów trzy lata po reformie systemu oświaty. Wybrane problemy. Studia Bibliol. AŚ. T.9: 2005 s. $195-221$, sum.

W r. 2001/2002.

481. PERKOWSKA Urszula: Biblioteka Towarzystwa Wzajemnej Pomocy Uczniów Uniwersytetu Jagiellońskiego - Bratniej Pomocy Studentów Uniwersytetu Jagiellońskiego w okresie autonomii galicyjskiej i dwudziestoleciu międzywojennym. W: Przestrzeń informacji i komunikacji społecznej. Pod red. Marii Kocójowej. Kraków 2004 s. 377-381.

\section{DZIEJE RUCHU NAUCZYCIELSKIEGO}

\section{Opracowania ogólne}

482. BACHULA Eugeniusz: Związek Nauczycielstwa Polskiego w powiecie hrubieszowskim w okresie stulecia. Hrubieszów-Lublin 2005 Polihymnia ss. 148, il. (Biblioteka Towarzystwa Regionalnego Hrubieszowskiego. T. 40).

483. CZARNECKA Iwona: Działalność Sekcji Szkolnictwa Specjalnego ZNP na rzecz osób głuchych (niesłyszących i niedosłyszących) w latach 1946-2001. Prz. Hist.-Ośw. R. 48: $2005 \mathrm{nr}$ 3/4 s. $169-184$.

484. ĆWIEK Marek: Z dziejów Związku Nauczycielstwa Polskiego i szkolnictwa na ziemi łaskiej. Łask $2005 \mathrm{ZNP}$ ss. 184, il.

XX-XXI w.

485. DĄBROWA Marian: Narodziny ZNP w Uniwersytecie Jagiellońskim. Trudne początki. Prz. Hist.-Ośw. R. 48: 2005 nr 1/2 s. 159-162.

486. DZIEJE Związku Nauczycielstwa Polskiego w Wyszkowie w latach 1975-2004. Oprac. Józef Dygan. Wyszków 2004 Edytor ss. 36, nlb. 2, il.

Treść: Wstęp s. 5-7; Działalność związku w poszczególnych kadencjach [1976-2006] s. 9-26; Działalność Oddziałowej Sekcji Emerytów i Rencistów s. 27-32; Prezesi oddziału s. 33; Członkowie związku w ogniskach s. 34-37.

487. GRZEŚ Bolesław: Geneza działalności Związku Nauczycielstwa Polskiego w Wielkopolsce w latach 1920-2005. Poznań 2005 Wydaw. Bociek; Zarząd Okręgu Wielkopolskiego Zw. Nauczycielstwa Pol. ss. 406, nlb. 1, tabl. 100.

488. JAKOWICKA Mariola: Formy dokształcania nauczycieli organizowane przez ZNP w okresie międzywojennym. Prz. Hist.-Ośw. R. 48: 2005 nr 1/2 s. 69-80.

489. KONIECZNY Zdzisław: Zarys dziejów Związu Nauczycielstwa Polskiego w Przemyślu 1905-2005. Przemyśl 2005 Zarząd Oddz. ZNP ss. 169, tabl. 14, il. ZNP Oddz. w Przemyślu.

490. KORNACKI Roman Albert: Związek Nauczycielstwa Polskiego w powiecie lubartowskim w latach 1905-2005. Lubartów-Lublin 2005 ZNP. Zarząd Oddz. Pow. w Lubartowie; BiS Zakł. Poligraficzny ss. 223, tabl. 15, il. ZNP. 
491. RYBA Mieczysław: Związek Nauczycielstwa Polskiego na Lubelszczyźnie w konflikcie z władzą i Kościołem w latach trzydziestych XX wieku. Rocz. Hum. T. 53: 2005 z. 2 s. 161-179, sum.

492. [STO] 100 lat ZNP. Ludzie, fakty, sprawy, wydarzenia. 1905-2005 Związek Nauczycielstwa Polskiego. Wstęp Bolesław Grześ; aut. Czesław Banach [i in.]. Warszawa-Kielce 2005 Wydaw. Pedag. ZNP ss. 574, il.

Encyklopedia.

493. SUBERLKA Tadeusz: Działalność wydawnicza Związku Nauczycielstwa Polskiego i jego poprzedników w latach 1905-2005 jako wyraz troski o rozwój nauczyciela w zawodzie. Prz. Hist.-Ośw. R. 48: $2005 \mathrm{nr}$ 1/2 s. 81-95.

494. SUDOŁ Józef: Powstanie i rozwój działalności ZNP w powiecie kolbuszowskim. Rocz. Kolbusz. Nr 6: 2002 [dr.:] 2003 s. 66-84.

W 1. 1945-75.

495. [SZEŚĆDZIESIĄT] 60 lat Związku Nauczycielstwa Polskiego na Śląsku Opolskim (1945-2005). Opole 2005 EDJ Edytorstwo; nakł. Zarządu Okręgu Opolskiego ZNP ss. 100, il.

Treść: Duda Jerzy, Dzionek Franciszek, Popera Janusz, Szelka Anna: 60 lat Związku Nauczycielstwa Polskiego na Śląsku Opolskim. Działalność ZNP na Śląsku Opolskim w latach 1945-2005 s. 9-31; Władze Okręgu ZNP w Opolu w latach 1950-2005 s. 32-42; Działacze Zarządu Okręgu ZNP w Opolu s. 43-53; Prezesi oddziałów ZNP w województwie opolskim w 2005 roku s. 54-62. Wspomnienia nauczycieli z lat 1945-1950 s. 63-96.

496. ZWIAZZEK Nauczycielstwa Polskiego na Ziemi Łomżyńskiej. Praca zbiorowa. Pod kier. Elżbiety Szleszyńskiej. Lomża 2005 Łomżyńskie Tow. Nauk. im. Wagów; Oddz. ZNP ss. 179, nlb. 3, il. ZNP.

Z treści: Żelechowska Teresa: Mój związek s. 9-11; Cieślik Ireneusz Waldemar: Wladze i działacze Związków Zawodowych Nauczycieli Polskich po I wojnie światowej s. 12-13; Wagner Irena: Tajne nauczanie w latach 1941-1944 na terenie dawnego powiatu lomżyńskiego s. 15-18; Brejtfus Zofia: Związek Nauczycielstwa Polskiego w okresie powojennym s. 21-22; Kamińska Ewa: Wybrane problemy z działalności Zarządu Okręgu ZNP w Lomży s. 23-27; Kołomyjska Helena: ZNP po reformie administracyjnej 1975 roku s. 28-29; Szeletyńska E.: Główne kierunki działania zarządu Oddziału ZNP w Łomży w okresie 2002-2006 s. 30-36; Wspomnienia s. 37-143; Noty biograficzne działaczy ZNP s. 145-166; Dodatek s. 169-178.

\section{Pamiętniki nauczycieli}

497. CZARNIK Andrzej: Moje powroty do przeszłości. [Cz.] 1: Dzieciństwo i młodość. Słupsk 2005 Wydaw. Pomorskiej Akad. Pedag. ss. 271, il.

Wspomnienia autora ur. w 1935 r., o powojennej nauce w Chełmnie, o studiach historycznych w Wyższej Szkole Pedagogicznej w Gdańsku i pracy w liceum w Białogardzie.

Rec.: Borzyszkowski Józef, Acta Cassubiana. T. 7: 2005 s. 337-340.

498. DZIĘGIEL Leszek: W pierścieniu pozorów. Arcana. Nr 63: 2005 s. 89-103.

Wspomnienia instruktora Pałacu Młodzieży w Katowicach z 1. 60. XX w.

499. GALANT Józef: Moja nauczycielska autobiografia. Rocz. Przem. R. 40: 2004 z. 4 s. $119-126$.

Wspomnienia żyjącego w 1. 1910-2003 pedagoga, opisujące dzieciństwo i naukę we Lwowie od $1918 \mathrm{r}$., pracę w szkołach koło Drohobycza, działalność w Związku Nauczycielstwa Polskiego, dalszą pracę pod oku- 
pacją radziecką i niemiecką oraz przeniesienie do Lipowca $k$. Drohobycza, walkę w AK, powojenną działalność i studia na Uniwersytecie Warszawskim zakończone doktoratem.

500. HALPERIN Józef: Ludzie są wszędzie. Tł. Józef Halperin, współpr. Zoja Perelmuter. Warszawa 2002 Aspra-Jr ss. 370, nlb. 2, tabl. 17, il.

Wspomnienia wojenne m.in. $\mathrm{z}$ pracy jako nauczyciel wiejski i urzędnik leśny w rejonie Baranowiczów, a od 1944 r. z walki w AK na Kielecczyźnie.

501. JAKÓBIEC Jan: Na drodze stromej i śliskiej. Autobiografia socjologiczna. Red. nauk., słowo wstępne, przypisy Grzegorz Ostasz. Kraków 2005 „Barbara” HUP, B. Gąsiorowska ss. 695, nlb. 1, XII, il.

Pamiętnik pochodzącego z rodziny chłopskiej nauczyciela germanisty (1876-1955) opisujący dzieciństwo i naukę w Słotwinie, kolejne etapy edukacji w Białej, Bielsku i Wadowicach, studia polonistyczne i germanistyczne na UJ, potem w Wiedniu, Monachium i Norymberdze, pracę pedagogiczną głównie w szkołach krakowskich, potem jako kuratora w Poznaniu oraz wojenną działalność jako konspiracyjnego wojewody krakowskiego.

502. MAĆKOWICZ Władysław: Wspomnienia polskiego nauczyciela Pogranicza (1893-1976). Oprac. Joachim Zdrenka. Toruń 2005 Adam Marszałek ss. 261, nlb. 1, il.

Pamiętnik opisujący dzieciństwo i naukę w Świętej oraz pracę pedagogiczną jako nauczyciela języka polskiego w tamtejszej szkole niemieckiej i kierownika Polskiej Szkoły Mniejszościowej w Radawnicy w 1. 1929-1939, jak również powojenną organizację oświaty w rodzinnych stronach, uzupełniony refleksjami o dziejach ziemi złotowskiej i polskiego szkolnictwa w 1. 1872-1924.

503. MOSZCZYŃSKA Stanisława: Ja nie do spowiedzi!. Lublin 2005 PWZN „Pront 6” ss. 111 .

Wspomnienia przedwojenne i wojenne z Lubelszczyzny, m.in. z Kolechowic i Tyśmienicy, a także z powojennej pracy jako nauczycielka m.in. w Białej Podlaskiej.

504. OWCZAREK Władysław, pseud. Bula: Ludzka droga. Szkoła przeżywania i pokonywania niepowodzeń i klęsk. Wyd. 2 popr. i uzup. Radom 2003 Wydaw. i Zakł. Poligrafii Inst. Technologii Eksploatacji ss. 351, il.

Wspomnienia wojenne żołnierza Batalionów Chłopskich i powojenne z pracy jako nauczyciel w Sycynie.

Wyd. 1. 1997.

505. RASZKA Jan: Pamiętnik artysty rzeźbiarza. Red. Joanna Walaszek. Cieszyn 2005 Społ. Kom. Odbudowy Pomnika Legionistów Śląskich ss. 189, nlb. 2, il.

Kolejne etapy życia rzeźbiarza, medaliera, legionisty (1871-1945): dzieciństwo w ewangelickiej rodzinie pracownika kolei, nauka w Pudłowie, Boguminie i Cieszynie, studia w Wiedniu i Paryżu, działalność artystyczna i wspóttworzenie polskiego szkolnictwa z zakresu sztuki użytkowej i dekoracyjnej w Krakowie.

506. SOSKA Zdzisław Marcin: Zapiski syberyjskie. Pamiętnik nauczyciela-katechety. Cz. 1. Milejów-Lublin 2004 Fund. Pomocy Szkołom Pol. na Wschodzie im. T. Goniewicza ss. 176, tabl. 32. Wspomnienia z Wierszyny w Rosji.

507. TOMCZYK Arkadiusz: Wspomnienia o Technikum Wychowania Fizycznego w Szczecinie 1952-1961. Szczecin 2002 Zakł. Usług Poligraficznych i Wydawniczych Jacek Plewnia ss. 254, il.

Toż. Cz. 2. Szczecin 2005 Zakł. Usług Poligraficznych i Wydawniczych Plewnia Jacek, Plewnia Maria ss. 128 , il. 


\section{ORGANIZACJE MLODZIEŻOWE}

508. BARTKOWIAK Przemysław: Organizacja Harcerska Związku Młodzieży Polskiej na Ziemi Lubuskiej w latach 1950-1956. W: Z dziejów Ziemi Lubuskiej po drugiej wojnie światowej. T. 1. Red. nauk. Czesław Osękowski. Zielona Góra 2005 s. 123-137.

509. BARTNIK Paweł: Prasa i działalność wydawnicza Niezależnego Zrzeszenia Studentów w Szczecinie w latach 1980-1990. W: Stan wojenny w skali kraju i Pomorza Zachodniego. Informacje źródłowe i refleksje. Materiały z sesji naukowej zorganizowanej przez Szczecińskie Towarzystwo Naukowe, Instytut Politologii Uniwersytetu Szczecińskiego, Archiwum Państwowe w Szczecinie i Instytut Pamięci Narodowej Oddział w Poznaniu, 26 listopada 2004 roku. Praca zbiorowa. Pod red. M. Machałek i Jana Macholaka. Szczecin 2005 s. 259-261.

510. BŁASZCZYK Krzysztof: Powstanie i działalność Niezależnego Zrzeszenia Studentów w Wyższej Szkole Pedagogicznej w Zielonej Górze w latach 1980-1982. W: Z dziejów Ziemi Lubuskiej po drugiej wojnie światowej. T. 1. Red. nauk. Czesław Osękowski. Zielona Góra 2005 s. 215-224.

511. BRYŁA Zbigniew: Harcerstwo w Szczekocinach 1916-2000 (szkice i wspomnienia). Szczekociny 2003 Komenda Kieleckiej Chorągiew ZHP im. Stefana Żeromskiego ss. 99, tabl. 16, il.

512. CHRABĄSZCZ Jerzy: Harcerze gorszego Boga. Związek Harcerstwa Polskiego w okresie transformacji ustrojowej państwa lat 1989-1990. Toruń 2005 Adam Marszałek ss. 513.

513. CZARNUCH Zbigniew: Osiem gawęd o moim zielonogórskim pedagogicznym raju. Cz. 1. Studia Ziel.-Górs. T. 11: 2005 s. 249-262.

Wspomnienia harcerskie $\mathrm{z}$ lat 50. i $60 . \mathrm{XX}$ w.

514. DROŃ Maciej: Jeździectwo w działalności wychowawczej drużyn kawalerii harcerskiej Związku Harcerstwa Rzeczypospolitej (1989-2000). Pr. Nauk. Akad. im. J. Dhugosza w Częstochowie. Kultura Fizyczna. [Z.] 6: 2005 s. 97-106, abstr.

515. JAROSIŃSKA Małgorzata: Harcerstwo żeńskie i ruch zuchowy w Rzeszowie (1912-1939). Rzeszów 2005 Mitel ss. 156, nlb. 1, il. Muzeum Okręg. w Rzeszowie.

516. JEST taka drużyna. Rys monograficzny działalności Drużyny Weteranów - Harcerzy Ziemi Łomżyńskiej - Kręgu Seniorów im. Leona Kaliwody na tle skautingu światowego i polskiego. Aneks do tomu 2. Red. prowadzący Marian Mieszkowski. Łomża 2004 Zw. Harcerstwa Pol. Hufiec Ziemi Łomżyńskiej w Łomży. Drużyna Weteranów - Harcerzy Ziemi Łomżyńskiej. Krąg Seniorów im. Leona Kaliwody ss. 131, il.

Z treści: Butler Tadeusz: Zarys historyczny IV Drużyny Harcerskiej ZHP im. Króla Jana III Sobieskiego przy Małym Seminarium Serafickim oo. Kapucynów w Łomży 1934-1939 s. 13-86; Zdjęcia uzupełniające do tomu I i II s. 89-97; Mieszkowska Krystyna: Promocja „Rysu monograficznego” s. 99-100.

517. KIELECKA Chorągiew Związku Harcerstwa Polskiego im. Stefana Żeromskiego w latach 1956-2000. Materiały Sesji Historycznej. Red. Andrzej Rembalski. Kielce 2003 Komenda Kieleckiej Chorągwi ZHP ss. 265, tabl. 16, il. Komenda Chorągwi ZHP im. Stefana Żeromskiego w Kielcach.

Treść: Rembalski A.: Wstęp s. 9-10; Rembalski A.: Stan badań nad historią harcerstwa Chorągwi Kieleckiej w latach 1956-2002 s. 11-16; Kateusz Anna: Struktura organizacyjna Chorągwi ZHP w Kielcach w latach 1956-2002. Władze Chorągwi. Instruktorzy chorągwi kieleckiej we władzach centralnych s. 17-30; Dubiel Włodzimierz: Hufiec ZHP im. Obrońców Westerplatte w Kielcach w latach 1956-1989 s. 31-48; Gadawski Adam, Marciniec Leszek: Hufiec ZHP im. 1000-lecia Państwa Polskiego w Busku Zdroju w latach 1956-2002 
s. 49-66; Groszek Jerzy, Groszek Rajmund: Hufiec ZHP im. Stefana Czarnieckiego we Włoszczowie w latach 1956-2002 s. 67-80; Bryła Zbigniew: Hufiec ZHP im. 8 Pułku Ułanów ks. J. Poniatowskiego w Szczekocinach w latach 1973-2000 s. 81-93; Kotlarz Stefan, Szczepańska Marianna, Wôjtowicz Janina: Hufiec ZHP im. Tadeusza Kościuszki w Staszowie w latach 1957-2002 s. 95-104; Jedynak Marek: Hufiec ZHP im. Partyzantów Ziemi Koneckiej w Końskich w latach 1956-2002 s. 105-122; Żychowski Andrzej: Hufiec ZHP im. hm. Jerzego Czerwińskiego w Opatowie w latach 1956-2002 s. 123-128; Cegielska Maria: Drużyny Nieprzetartego Szlaku w Choragwi Kieleckiej ZHP w latach 1957-2002 s. 129-133; Kruk Stanisław: Dom Harcerza im. Natalii Machałowej w Kielcach - Białogonie s. 135-142; Hendler Julian: Księgi Instruktorów Seniorów „Lysica” w Chorągwi Kieleckiej ZHP s. 143-147; Kubiec Elżbieta: Harcerskie Miejsca Pamięci na terenie Chorągwi Kieleckiej ZHP im. Stefana Żeromskiego s. 149-199; Siuda Tadeusz: Odrodzenie harcerstwa po II wojnie światowej s. 201-211; Główka Jan: Zbiory przekazane przez harcmistrza Tadeusza Paradowskiego do Muzeum Narodowego w Kielcach s. 213-218; Skotnicka Janina: Badania etnograficzne na terenie Doliny Wilkowskiej s. 219-220; Rembalski A.: Harcmistrz Jerzy Krukowski 6 VIII 1932 - 4 VII 2003 s. 221-224; Statut Muzeum Harcerstwa w Warszawie s. 225-227; Mazur Ryszard: Działalność programowa Komendy Kieleckiej Chorągwi Związku Harcerstwa Polskiego w latach 1956-2002 s. 229-265.

518. KLISTALA Jerzy: Harcerstwo w miastach i powiatach Bielska i Białej w latach 1925-1949. Relacje, wspomnienia, życiorysy. Bielsko-Biała 2005 Jerzy Klistała ss. 383, il.

519. KOŚCIELAK Zbigniew: Ogniska wspomnień. W kaliskim harcerskim kręgu 1956-2005. Kalisz 2005 Komenda Hufca ZHP ss. 95, nlb. 2, il.

520. KOWALAK Czesław: Legnickie harcerstwo w latach 1945-2000 (Kalendarium). Szkice Leg. T. 25: 2004 s. 307-340.

521. KRZANOWSKI Adam: Kształtowanie postaw skautów i harcerzy na podstawie treści historycznych stosowanych w pracy wychowawczej w latach 1911-1939. W: Polska i jej wschodni sąsiedzi. T. 6. Pod red. Andrzeja Andrusiewicza. Rzeszów 2005 s. 67-75. (Studia Wschodnioznawcze).

522. MATERIALY do dziejów Koła Naukowego Historyków Studentów Uniwersytetu Jagiellońskiego. Studenckie Zesz. Nauk. UJ. [T.] 14: Studenckie Zesz. Hist. Z. 5: 2004 s. 177-246.

Treść: Haręzga Dagmara: Sprawozdanie Zarządu z działalności Koła Naukowego Historyków Studentów Uniwersytetu Jagiellońskiego za okres od 9 grudnia 2002 r. do 10 grudnia 2003 r. s. 177-186; Popielska Joanna: Działalność Sekcji Historii Grecji Koła Naukowego Historyków Studentów UJ w roku akademickim 1992/1993 s. 187; Popielska J.: Działalność Sekcji Historii Starożytnej Koła Naukowego Historyków Studentów UJ w latach akademickich 1997/1998, 1998/1999 i 1999/2000 s. 188-190; Weiss Anna, Fokt Krzysztof, Szymborski Wiktor: Sekcja Mediewistyczna [w 1. 1991-2003] s. 191-222; Szymborski W.: Sekcja Badania Laciny Średniowiecznej [w 1. 1988-1989] s. 223-224; Piwoński Marek: Sekcja Historii Rzeczypospolitej Szlacheckiej [od 2003 r.] s. 225; Pudłocki Tomasz: Sprawozdanie z działalności Sekcji Historii XX Wieku [od 1997 r.] s. 226-232; Sykulski Leszek: Dzieje Sekcji Historii Walk Polaków o Niepodległość KNHS UJ w latach 1984-2003 s. 233-238; Markiewicz Anna: Sekcja Historii Miasta Krakowa [w 1. 1992-2003] s. 239-240; Haręzga G.: Sprawozdanie z działalności Sekcji Historii Polski Południowo-Wschodniej KNHS UJ [od 2001 r.] s. 241-243; Figlewicz Paweł: Sprawozdanie z działalności Sekcji Ikonografii Historycznej [od 1997 r.] s. $244-246$.

523. MAZURKIEWICZ Mirosław: Przy dogasającym ognisku... Radom 2005 Społeczny Komitet Ratowania Zabytków Radomia ss. 415, il.

Związek Harcerstwa Polskiego w Radomiu, XX w.

524. NIEZALEŻNY ruch młodzieżowy w Polsce po drugiej wojnie światowej (1945-2001). Zbiór studiów. Pod red. Ryszarda Sudzińskiego. Toruń 2005 Wydaw. UMK ss. 226, nlb. 5, il. UMK.

Materiały z konferencji, Toruń, 14 XI 2003 r. 
Treść: Sudziński R.: Wprowadzenie s. 7-10; Szuba Ludwik: Działalność Powszechnej Organizacji „Shużba Polsce" w latach 1948-1956 s. 11-35; Golon Mirosław: Młodzieżowe organizacje konspiracyjne w wybranych ośrodkach Pomorza Nadwiślańskiego w okresie stalinowskim s. 37-59; Czyżniewski Marcin: Organizacje młodzieżowe w propagandzie okresu stalinowskiego s. 61-68; Rozynkowski Waldemar: Akademicka sekcja „Caritas" przy parafii świętojańskiej w Toruniu w latach 1945-1946. Powstania i pierwsze miesiące działalności s. 69-77; Gomoliszek Joanna: Organizacyjne czasopisma studenckie na UMK w latach 1945-1973 s. 79-87; Szturo Grzegorz: Młodzież polska w poglądach wybranych ośrodków emigracji polskiej w okresie października 1956 roku s. 89-99; Polak Wojciech; Niezależne działania młodzieży szkolnej województwa toruńskiego w okresie stanu wojennego i w latach następnych (13 XII 1981 - 4 VI 1989) s. 101-127; Licbarski Robert: Federacja Młodzieży Walczącej w Gdańsku w latach 1984-1990 s. 173-204; Girzyński Zbigniew: Organizacje młodzieżowe w okresie transformacji na przykładzie Federacji Młodych Ruchu Odbudowy Polski w latach 1996-2001 s. 205-226.

525. PACŁAWSKI Ryszard: Gra o harcerstwo. Warszawa-Sanok 2005 Paleta-Art R. Paszkowski; Stow. Wychowawców Eleusis ss. 257, il.

Wspomnienia naczelnika Związku Harcerstwa Polskiego, po 1989 r.

526. RABIŃSKI Jarosław: Konstanty Turowski - działacz Stowarzyszenia Katolickiej Młodzieży Akademickiej „Odrodzenie” . W: Peregrinatio ad veritatem. Studia ofiarowane profesor Aleksandrze Witkowskiej OSU z okazji 40-lecia pracy naukowej. Red. Urszula Borkowska [i in.]. Lublin 2004 s. $431-439$.

527. ROSIŃSKI Henryk: Wspomnienia z działalności w Związku Młodzieży Polskiej „Wici” po przełomie politycznym 1956 roku w powiecie włocławskim. Rocz. Lud. Tow. Nauk-Kult. Oddz. w Krakowie. Nr 6: 2005 s. 154-168.

528. SOWIECKIEMU zniewoleniu - nie. Harcerska druga konspiracja (1944-1956). Praca zbiorowa. Z przedm. Stanisława Broniewskiego „Orszy”. Warszawa 2005 Lad ss. 252, nlb. 1, il.

Antologia wspomnień.

529. SUCHMIEL Jadwiga: Akademickie Koło Sądeczan (1922-1939). Rocz. Sqdec. T. 33: 2005 s. $225-234$.

Na Uniwersytecie Jagiellońskim.

530. SZCZEREPA Maciej, Szczerepa Wojciech: Działalność hufca ZHP we Lwówku Śląskim w latach 1945-1956. Rocz. Jel.-Górs. T. 37: 2005 s. 191-200, shrnutí, Zsfg.

531. SZYMANOWICZ Adam: Naczelna Komenda Organizacji Harcerskiej na Warmię i Mazury (1920 rok). Kom. Mazur.-Warm. [R. 49]: 2005 nr 2 s. 253-259, Zsfg.

532. ŚMIERZCHALSKI-WACHOCZ Dariusz: Rola ZMP w procesie ateizacji i demoralizacji młodego pokolenia na Środkowym Nadodrzu w latach 1948-56. Studia Paradyskie. T. 15: 2005 s. $175-192$.

533. WDOWICKI Maciej: Katolickie Stowarzyszenie Młodzieży w Bydgoszczy. Kronika z lat 1912-2002. Kron. Bydg. T. 26: 2004 [dr.:] 2005 s. 387-394.

534. WIELGOSZ Julian: Związek Młodzieży Robotniczej w Krakowie (grudzień 1956). Krak. Studia Matopol. Nr 7: 2003 s. 349-359, sum.

535. WILCZYŃSKI Leszek: Młode Polki. Katolickie Stowarzyszenie Młodzieży Żeńskiej w Wielkopolsce 1918-1939. Toruń 2005 Adam Marszałek ss. 290, il., sum. 
536. WOŁOSZYN Jacek: Członkowie Związu Młodzieży Polskiej w województwie lubelskim wobec Kościoła katolickiego - przyczynek do dziejów mentalności młodzieży. Pamięć i Sprawiedliwość. 2005 [nr] 1 s. 71-97, sum.

537. ZAKRZEWSKI Józef: 30 lat działalności Ogólnopolskiego Koła Wychowanków Średnich Szkół Grudziądza (1974-2004). Rocz. Grudz. T. 16: 2005 s. 372-374.

538. ŻELAŚKIEWICZ Jerzy, pseud. Korab: Szarymi Szeregami... Z dziejów harcerstwa w Książu Wielkim. Warszawa 2005 Jerzy Żelaśkiewicz ss. 134, tabl. 2, il., mapy.

Opracowala Anna Gruca 